Provided for non-commercial research and education use. Not for reproduction, distribution or commercial use.

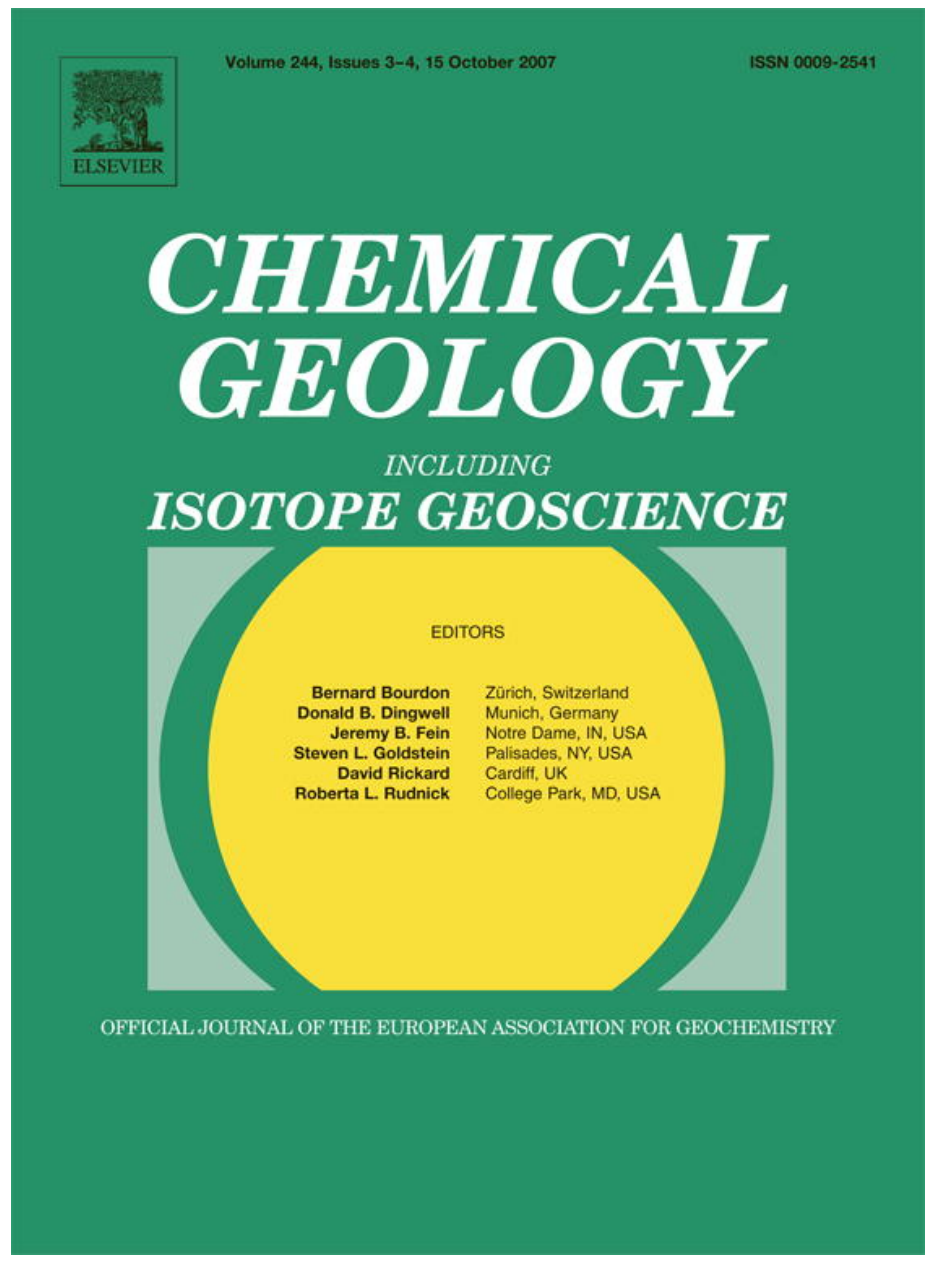

This article was published in an Elsevier journal. The attached copy

is furnished to the author for non-commercial research and education use, including for instruction at the author's institution, sharing with colleagues and providing to institution administration.

Other uses, including reproduction and distribution, or selling or licensing copies, or posting to personal, institutional or third party websites are prohibited.

In most cases authors are permitted to post their version of the article (e.g. in Word or Tex form) to their personal website or institutional repository. Authors requiring further information regarding Elsevier's archiving and manuscript policies are encouraged to visit:

http://www.elsevier.com/copyright 


\title{
Organic-rich sediments in brine-filled Shaban- and Kebrit deeps, northern Red Sea
}

\author{
Reiner Botz ${ }^{\mathrm{a}, *}$, Mark Schmidt ${ }^{\mathrm{a}}$, Hermann Wehner ${ }^{\mathrm{b}}$, Heinz Hufnagel ${ }^{\mathrm{b}}$, Peter Stoffers ${ }^{\mathrm{a}}$ \\ ${ }^{a}$ Institut für Geowissenschaften, Universität Kiel, Olshausenstr. 40, D-24118 Kiel, Germany \\ b Bundesanstalt für Geowissenschaften und Rohstoffe, Postfach 510153, D-30631 Hannover, Germany
}

Received 4 August 2006; received in revised form 3 July 2007; accepted 7 July 2007

Editor: B. Bourdon

\begin{abstract}
The element compositions $\mathrm{Si}, \mathrm{Ca}$ and $\mathrm{Al}$ of up to $21.1 \mathrm{ka}$ old sediments in about $10 \mathrm{~m}$ long cores from the southern basin of the Shaban and Kebrit deeps in the northern Red Sea allowed a classification of major sediment types in carbonate sands and -muds and siliceous oozes. A FeOOH-enriched sediment horizon and a few samples with high $\mathrm{Zn}$ values in the Kebrit core indicate a hydrothermal origin probably near the brine-sea water interface with subsequent transport of hydrothermal compounds into the deep sediments.

High organic carbon contents up to $8.4 \%$ are positively correlated with the Ba concentrations, which suggests that high bioproductivity and rapid deposition $\left({ }^{14} \mathrm{C}\right.$ dating suggests a sedimentation rate near $\left.70 \mathrm{~cm} / \mathrm{ka}\right)$ led to the formation of sapropelic sediments between 11.8 and $13.6 \mathrm{ka}$ (Younger Dryas). Organic petrological observations showed that the sediment organic material largely consists of $<20 \mu \mathrm{m}$-sized roundish fecal pellets (intimate mixtures of organic matter and inorganic constituents) and bituminite. Terrestrial organic matter (pollens of land plants, fusinite etc.) is very rare in the sediment cores from both deeps.

Organic-geochemical investigations of kerogens and organic extracts show that a significant (hydrothermal) hydrocarbon production did not occur in near-surface sediments of the Shaban and Kebrit deeps. Rock Eval pyrolysis of kerogens characterised the organic matter to be of type II quality. The $\delta^{13} \mathrm{C}$ values of the kerogens from the most prominent sapropel in the Shaban deep indicate an enrichment of $\left({ }^{12} \mathrm{C}\right.$-rich $)$ nutrients in the water column during postglacial sapropel formation in the Younger Dryas. The $n$-alkane spectra are dominated by short chain lengths between $n-\mathrm{C}_{15}$ and $n-\mathrm{C}_{25}$. Prevailing $n-\mathrm{C}_{15}$ to $n-\mathrm{C}_{25}$ alkanes in low mature sediments are indicative of algal and microbial source. Pristane/phytane ratios are generally low $(<1$ to $\sim 1)$ which suggests that anoxic conditions prevailed within the anaerobic brine-filled deeps for the whole time covered by the sediments. This again indicates that sapropel formation was caused by high bioproductivity in the northern Red Sea rather than episodic stagnation with better preservation of the organic matter.

Long-chain alkenones and sterols are the dominating compounds of the lipid fraction. Cholesterol contents in the sediment cores reflect phases of eukaryotes production in the water column, whereas the positive correlations of dinosterol with TOC and the amounts of total extract suggests that the major organic carbon source in the northern Red Sea during postglacial high-productivity stages were dinoflagellates. Another important carbon source, however, is indicated by the occurrence of 22,29,30-trisnorhopan21-one (TNH). Although the formation of TNH from its precursors is not fully understood, this compound probably results from microbial degradation of intact bacteriohopanepolyols (BHP), which can be used as indicators for bacterial abundances and phyla. TNH is most likely produced at the brine-sea water interface where sedimenting organic matter accumulates and, if the redoxcline
\end{abstract}

\footnotetext{
* Corresponding author. Tel.: +49 431 8802854; fax: +49 4318804376.

E-mail address: rb@gpi.uni-kiel.de (R. Botz).
} 
corresponds to the density gradient, the organic matter is subjected to efficient aerobic bacterial degradation processes. However, during high bioproductivity stage (Younger Dryas) the redoxcline was probably higher in the water column and thus, a significant TNH production at the brine-sea water interface did not occur at times of sapropel formation in the northern Red Sea deeps.

(c) 2007 Elsevier B.V. All rights reserved.

Keywords: Red Sea deeps; Biomarker; Brine; Sapropel; Trisnorhopane

\section{Introduction}

\subsection{Geographical background, Red Sea water masses}

The Red Sea, a large approximately $2000 \mathrm{~km}$ long and $230 \mathrm{~km}$ wide marginal basin, is part of the AfricanArabian rift system. It is a young ocean basin often called an ocean in statu nascendi. To the south the Red Sea is connected to the Gulf of Aden through the shallow, $137 \mathrm{~m}$ deep Bab el Mandeb strait (Werner and Lange, 1975). In the North the Gulfs of Suez and Aqaba are located. The Red Sea lies in an arid region where large mean net evaporation $(2.06+/-0.22 \mathrm{~m} /$ year; Sofianos and Johns, 2002) exceeds precipitation. At water temperatures between 22 and $24{ }^{\circ} \mathrm{C}$ in winter and up to $28{ }^{\circ} \mathrm{C}$ in summer highly saline waters up to $40 \mathrm{psu}$ form in the northern Red Sea (Edwards, 1987). As a consequence anti-estuarine circulation develops in which relatively fresh surface waters from the Gulf of Aden flow into the Red Sea, while deep water spills out over the sill of Bab el Mandeb. Formation of "Red Sea Water" (RSW) occurs in the northernmost part of the basin (Eshel et al., 1994; Eshel and Naik, 1997), which then flows towards the south as a dense, cool and salty layer. Below a water depth of about $300 \mathrm{~m}$ a still denser "Red Sea Deep Water" occurs with constant ( $40.5 \mathrm{psu}$ ) salinity, which is formed during the winter months in the Gulfs of Suez and Aqaba (Woelk and Quadfasel, 1996). However, the thermohaline control on the two surface water layers is modified by wind action (Maillard, 1972; Quadfasel and Baudner, 1993; Sofianos and Johns, 2002). During the entire year predominating winds blow from NW and NNW. South of about $19^{\circ} \mathrm{N}$, however, the prevailing wind direction during winter time is SSE (Edwards, 1987). Details about Red Sea water masses and models including hydraulic exchange processes are presented by Siddall et al. (2004) and literature cited.

\subsection{The Kebrit and Shaban deeps}

In the southern Red Sea an axial trough with a continuous rift valley is developed. In contrast, the northern Red Sea has no axial rift valley but instead a few isolated deeps exist. They reflect an early initial phase of seafloor spreading with punctiform emplacement of oceanic crust (Bonatti, 1985). The deeps are brine-filled due to leaching of sub-bottom Miocene evaporites (Manheim, 1974) with salinities up to $26 \%$ (Hartmann et al., 1998a,b).

The Shaban deep with a size of approximately $60 \mathrm{~km}^{2}$ is located in the northern Red Sea between $26^{\circ} 12^{\prime} \mathrm{N}$ to $26^{\circ} 15^{\prime} \mathrm{N}$ and $35^{\circ} 19^{\prime} \mathrm{E}$ to $35^{\circ} 24^{\prime} \mathrm{E}$ (Fig. 1). It was originally discovered during a Preussag research cruise in 1981 (Preussag, 1984) but the northern and western basins were detected later (Pautot et al., 1984). Its maximum water depth is about $1540 \mathrm{~m}$, which is about $350 \mathrm{~m}$ deeper than the surrounding ocean floor. Steep slopes form the southern and eastern walls. A submarine ridge (900 $\mathrm{m}$ water depth) exhibiting two adjacent saddles stretches in $135^{\circ}$ direction and separates the Shaban deep into four subbasins. A connection between the two larger southern subbasins exists in 1420-1430 m water depth at the SE-end of the ridge. The brine-sea water interface occurs at a water depth near $1325 \mathrm{~m}$ in all basins. The brine has a temperature of approximately $23{ }^{\circ} \mathrm{C}$ and a $\mathrm{pH}$ value near 6.0 (Hartmann et al., $1998 \mathrm{a}, \mathrm{b}$ ). All four subbasins are filled with $\mathrm{H}_{2} \mathrm{~S}$-free anoxic $(<0.3 \mathrm{mg} / 1$ dissolved oxygen, Hartmann et al., 1998a,b) brine waters with salinity (S) values of $25.6-26.1 \%$, close to $\mathrm{NaCl}-$ saturation (Hartmann et al., 1998a,b).

The occurrence of brine in the Kebrit deep, which is located at about $24^{\circ} 43^{\prime} \mathrm{N}$ and $36^{\circ} 17^{\prime} \mathrm{E}$, was first described by Bäcker and Schoell (1972). The brinesea water interface is at about $1472 \mathrm{~m}$. Here the acidic $23.4{ }^{\circ} \mathrm{C}$ warm brine $(\mathrm{pH} \sim 5.5, \mathrm{~S} \sim 27.8 \%$, Hartmann et al., 1998a,b) is only about $80 \mathrm{~m}$ thick, which is in contrast to the approximately $200-250 \mathrm{~m}$ thick brine $(\mathrm{pH} \sim 6.0)$ in the southern/eastern subbasins of the Shaban deep. Moreover, whereas the Kebrit brine is enriched with $\mathrm{H}_{2} \mathrm{~S}$ (12-14 mg sulphur/l), the Shaban brine contains a significant higher dissolved sulfate content than the Kebrit brine (Hartmann et al., 1998a,b).

\subsection{Red Sea sediments}

\subsubsection{General}

Red Sea sediments consist largely of carbonates (Milliman et al., 1969) but wind activity transports 

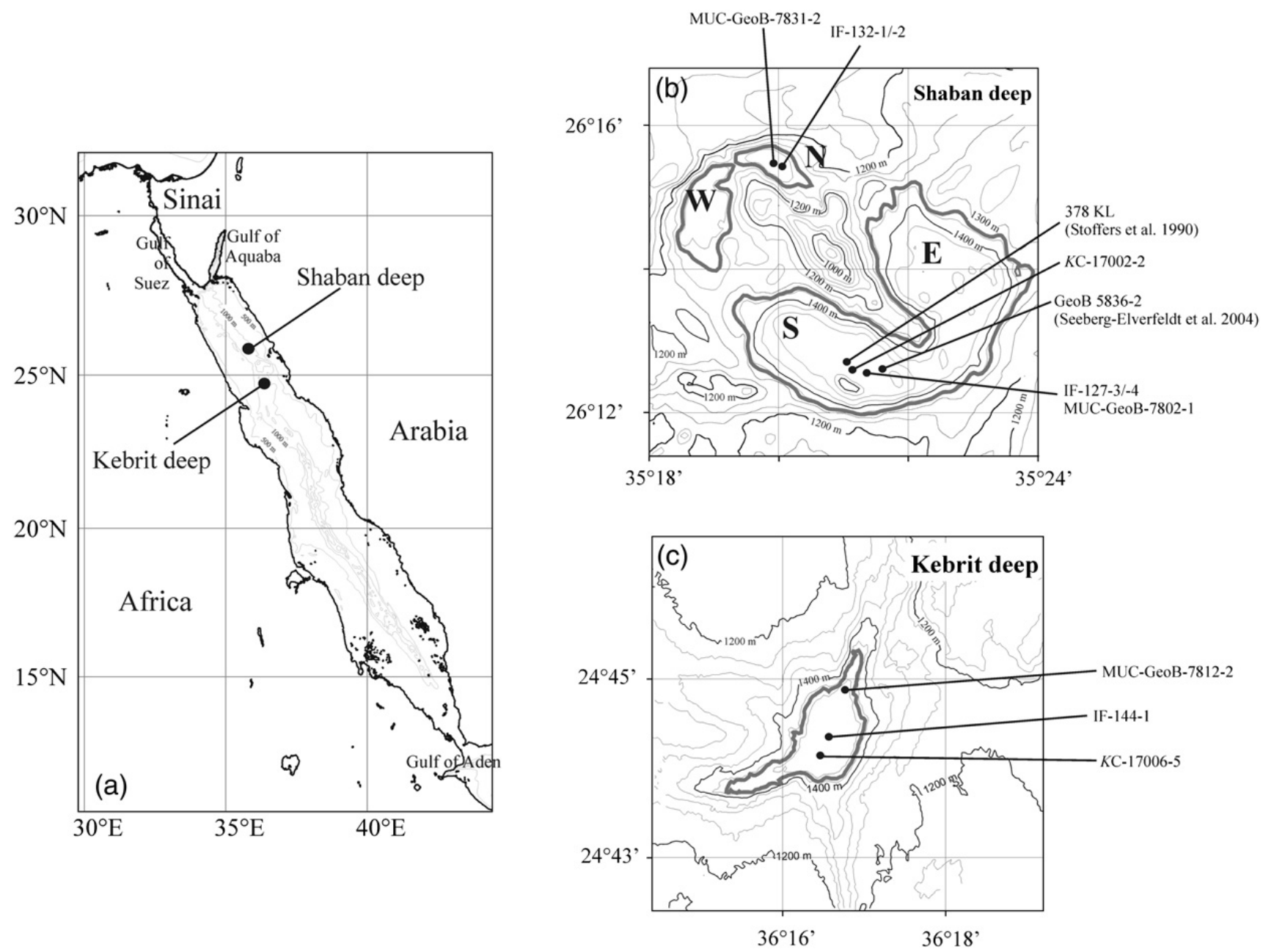

Fig. 1. a-c Bathymetry and sampling stations (Kasten Corer-, MUltiCorer-, Insitu Filtration-stations) of brine-filled Shaban and Kebrit deeps from the Red Sea. Sediment core stations known from literature are also marked in Fig. 1b. The interface between the Kebrit and the Shaban brine and Red Sea Deep Water are plotted as shaded lines.

significant amounts of detritic quartz, feldspar and clay minerals into the Red Sea (Arz et al., 2003). Much of the carbonate (and opaline) constituents of Red Sea sediments are biogenic products although primary production in the Red Sea north of $18^{\circ} \mathrm{N}$ is generally low and similar to that in oligotrophic gyre centers (Levanon-Spanier et al., 1979; Weikert, 1982). Numerous studies of Holocene and Upper Pleistocene Red Sea sediments have revealed highly variable sediment compositions representing major changes in fauna and flora, which suggests significant climatic and paleoceanographical changes (e.g. Milliman et al., 1969; Deuser and Degens, 1969; Rossignol-Strick, 1987; Thunell et al., 1988; Almogi-Labin et al., 1991). In particular, the Red Sea sediment record contains aplanktonic intervals that represent glacial periods when Red Sea salinities were in excess of the lethal limit for planktonic foraminifera (Hemleben et al., 1996b; Siddall et al., 2004 and literature cited thereunder).
Milliman et al. (1969) estimated that more than half of the deep-sea carbonates in the Red Sea precipitated inorganically from seawater. Lithified carbonate crusts or (semi-)lithified carbonaceous sediments in cores are composed of the minerals calcite, high Mg-calcite, aragonite, dolomite and occasionally rhodochrosite and siderite which formed by inorganic mineral precipitation at the sea floor and during sediment diagenesis (Herman, 1965; Gevirtz and Friedman, 1966; Milliman et al., 1969; Stoffers and Botz, 1989).

\subsubsection{Sediments of the Shaban and Kebrit deeps}

Sediment cores from the Shaban deep were recovered on the occasions of several German research cruises to the northern Red Sea ( $R V_{S}$ Valdivia - Menor I and II, Sonne 29, Meteor 31-2, 44-3, 52-3). All cores from the southern Shaban basin contain finely-laminated greenish to black sediments (Fig. 2; Stoffers et al., 1990; Hemleben et al., 1996a; Seeberg-Elverfeldt et al., 


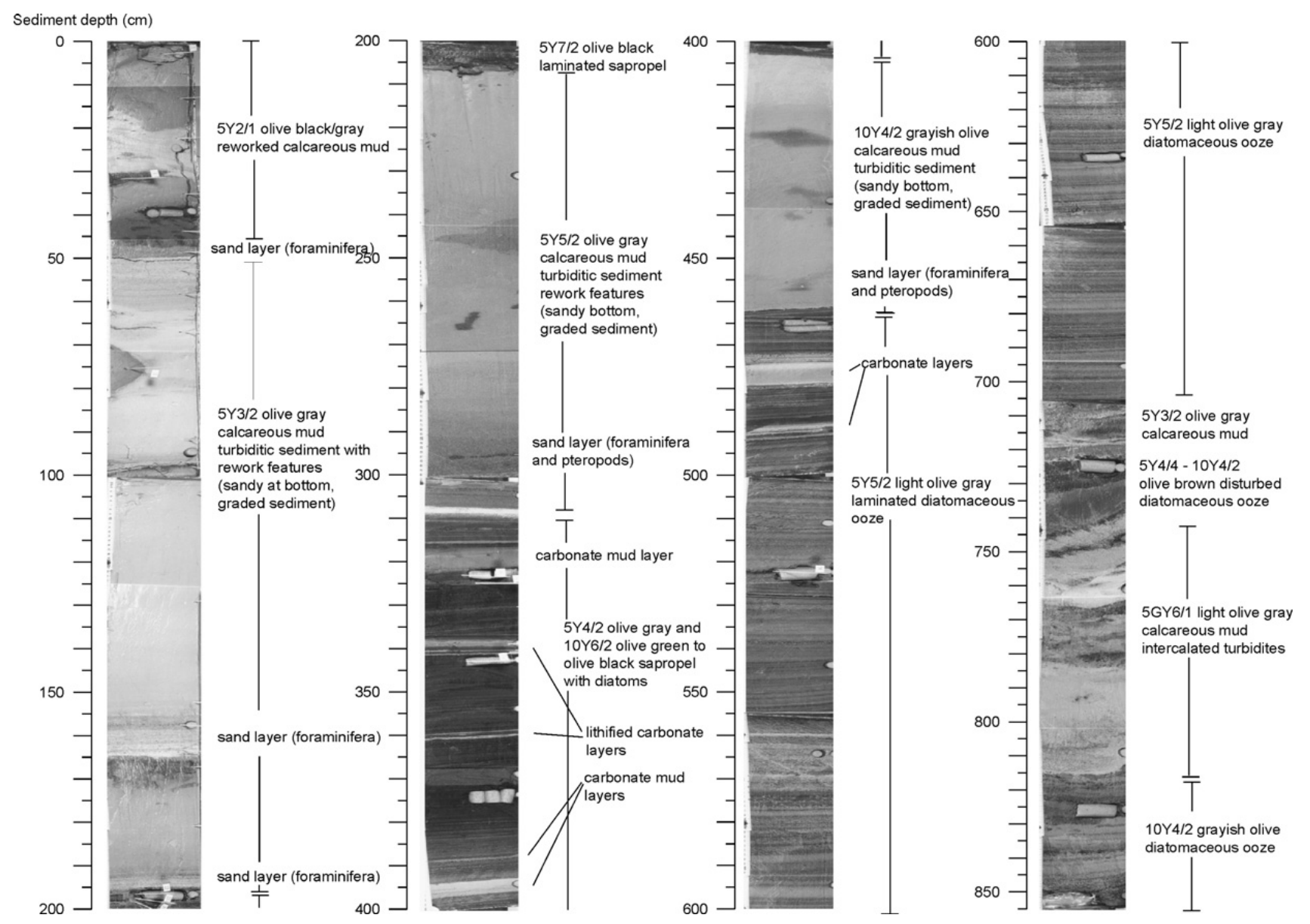

Fig. 2. Major sediment types of sediment core KC 17002-2 (Shaban deep). The color code is given after the Rock Color Chart (1991). Fluffy surface sediment is missing. The $755 \mathrm{~cm}$ to $850 \mathrm{~cm}$ sediment segment is probably disturbed by coring.

2004a,b), whereas the Kebrit cores often contain darkgray laminated sediments on top of carbonate deposits (Hemleben et al., 1996a). Laminated sediments of both deeps are frequently interrupted by light-colored macroscopic relatively homogenous sandy to silty (carbonate) mud layers. According to Seeberg-Elverfeldt et al. (2004b) laminated sediments in the Shaban deep contain light layers mainly composed of coccoliths, terrigenous matter and diatom fragments while dark layers consist almost exclusively of diatom frustules. The authors assumed a seasonal variation with coccoliths as summer signal and diatoms representing fall/ winter deposition. Such a sedimentation model requires an undisturbed pelagic sedimentation by vertical sediment transport through the water column and brine body. A further prerequisite for the formation of finely-laminated sediment is that bioturbation does not disturb the sediment layers. The latter holds true for laminated sediments deposited under anaerobic conditions (Kemp, 1996; Kemp et al., 2000) especially under the influence of $\mathrm{NaCl}$-saturated brine. However, for the Red Sea deeps under consideration undisturbed sedi- mentation over long periods of time is not very likely to occur as they are submarine depressions where turbiditic activity largely influences sedimentation. Moreover, not much attention has been given to the fact that the acidity of the brines (pH 5.5-6) may influence the sediment composition of the deeps due to carbonate dissolution (Schmidt et al., 2006).

Previous studies of sedimentary organic matter in the Atlantis II-, Kebrit- and Shaban deep sediments showed indications of low-temperature hydrothermal maturation and petroleum generation (Simoneit et al., 1987; Michaelis et al., 1990). The present work, however, focuses on the formation of organic-rich sediments in the Shaban- and Kebrit deeps and their relations to paleoceanographic variations in the northern Red Sea. Sapropelic layers of Red Sea sediments have formerly been recognized (Rossignol-Strick et al., 1982; Ivanova, 1985; Rossignol-Strick, 1987; Locke and Thunell, 1988; Thunell et al., 1988). Basically two models of sapropel formation exist: "high-production" vs. "good-preservation/stagnation" (Olausson, 1961; Calvert, 1983; Almogi-Labin et al., 1991). However, 
postdepositional oxidation of sapropels in contact with aerobic bottom waters plays a major role in the preservation of sapropels ("burn-down" effect, Löwemark et al., 2006). When sedimentation of organic matter within anaerobic brine-filled deeps occurs an aerobic oxidation of the deposited sapropel is prevented. Hence, investigations of sapropelic sediments within anaerobic (Red Sea) deeps are very helpful when deducing the paleoceanographic conditions of sapropel formation. Recently, Coulibaly et al. (2006) found evidence in trace metal contents (e.g. Fe, Mn, $\mathrm{Zn}$ ) of Red Sea sediments, which indicated, glacial to interglacial variations of the redox boundary relative to the brine-sea water interface. Our geochemical investigations of sedimentary organic matter deposited within the Kebrit and Shaban deeps provide further knowledge on the redox history of the Red Sea during the last $21 \mathrm{ka}$.

\section{Methods}

\subsection{Sampling}

During Meteor cruise 31-2 (cruise in 1995; Hemleben et al., 1996a) a $852 \mathrm{~cm}$ long sediment kasten core (KC 17002-2) was taken in the southern subbasin of the Shaban deep $\left(26^{\circ} 12.6 \mathrm{~N} ; 35^{\circ} 21.1 \mathrm{E}\right)$ at a water depth of $1549 \mathrm{~m}$. This core contains laminated light olive gray (siliceous oozes) or olive green to olive black-colored finely-laminated (sapropel) sediments, which are frequently interrupted by light-colored brownish or grayish (olive) homogenous sediment horizons of variable thicknesses (Fig. 2). The light-colored sediments contain a relatively high carbonate content (Table 1). Although the top of the core (probably more than one meter sediment, see below) is missing due to overpenetration sediment core 17002-2 can closely be correlated with sediment core $378 \mathrm{KL}$ (Stoffers et al., 1990) and also with core GeoB 5836-2 (SeebergElverfeldt et al., 2004b), which were taken in close vicinity (within distances of a few hundreds of meters) to core 17002-2 also from the southern subbasin of the Shaban deep (Fig. 1b).

An approximately $10 \mathrm{~m}$ long sediment core $(K \mathrm{C}$ 17006-5) was taken in the centre $\left(24^{\circ} 43.2 \mathrm{~N} ; 36^{\circ} 16.5 \mathrm{E}\right)$ of the Kebrit deep at $1567 \mathrm{~m}$ water depth (Fig. 1c). The upper meter of this core consists of dark greenish to gray laminated sediments intercalated with light olive gray homogenous mud and layers enriched in foraminifera (Fig. 3). Between one and two meter core depth a horizon of moderate brown to reddish limonitic sediments (several $\mathrm{cm}$ thick layers, Fig. 3) and $\mathrm{mm}$ to $\mathrm{cm}$ thick medium to dark greenish to gray organic-rich layers alternate with light (olive) gray carbonate (foraminifera) sand and mud. Below two meters core depth homogenous light olive gray carbonate muds are present.

Sediment sampling followed the occurrence of different lithological units in each core. Organic-rich sediments were sampled onboard during Meteor cruise M31-2 in 1995 in great detail (Table 1) and the samples were stored in a deep freezer $\left(-18{ }^{\circ} \mathrm{C}\right)$. Prior to geochemical analysis about 10 to 30 grams of each sample were washed salt-free $(0.47 \mu \mathrm{m}$-filtration using distilled water until the filtrate did not show further reaction with $\mathrm{AgNO}_{3}$ ), freeze-dried and homogenized by slight grinding. Organic-petrographical and geochemical laboratory analyses were performed within weeks up to several months after the cruise.

Surface $(0-1 \mathrm{~cm})$ sediment samples MUC-GeoB7802-1 and MUC-GeoB-7812-2, recovered from the Shaban deep (Fig. 1b) and the Kebrit deep (Fig. 1c), respectively, were taken with a multicoring device during Meteor cruise M52-3 (Arz et al., 2002).

A modified "Kieler In situ Filtration" (Petrick et al., 1996) unit attached to a CTD-rosette (SeaSunTechnology, Germany) was used to sample particles from the brine-sea water interfaces of Shaban and Kebrit deep during M52-3 (Botz et al., 2002). In situ filtration stations marked in Fig. 1b (Shaban deep), were located at the brine-sea water interfaces at about $1327-1329 \mathrm{~m}$ (IF 127-3/-4), and between 1331 and $1332 \mathrm{~m}$ water depth (IF-132-1/-2). The Kebrit brine-sea water interface was sampled at station IF-144-1 at a water depth of about $1471 \mathrm{~m}$ (Fig. 1c). The filtration device pumped water/brine through a sequence of a $0.2 \mu \mathrm{m}$ polycarbonate and a $1-3 \mu \mathrm{m}$ glass fiber filter $(\varnothing$ $140 \mathrm{~mm})$. The initial water pump velocity of about $1.1 \mathrm{~L} / \mathrm{min}$ dropped down to $50 \%$ during the in situ filtration at the brine-sea water interface within $30 \mathrm{~min}$. The sampling depth interval varied between 0.5 and $2 \mathrm{~m}$ depending on sea conditions within the 30 min filtration procedure.

\subsection{Carbonate-, organic carbon-, total sulfur contents}

Carbonate-free (2 N HCl-treated) sediment samples were analysed for their organic carbon contents by routine analysis using $10 \mathrm{mg}$ sample material in a CHNS-Analyser (Carlo Erba Instruments).

Total carbon and total sulfur were measured with a CS-Analyser (combustion at $1800{ }^{\circ} \mathrm{C}$; Leco Instruments). Carbonate contents were then calculated from the carbon data by subtraction method. 
Table 1

Geochemical parameters (Total Organic Carbon, $\mathrm{CaCO}_{3}$-content, Total Sulfur, ${ }^{14} \mathrm{C}$-sediment age based on AMS), and selected element composition measured by XRF of sediment cores 17002-2 and 17006-5. For $\mathrm{SiO}_{2}$ excess and $\mathrm{Ba}_{\text {excess }}$ calculations the following Equations were used: (1) $\mathrm{SiO}_{2}$ excess $(\%)=\mathrm{SiO}_{2}(\%)-3.19 \times \mathrm{Al}_{2} \mathrm{O}_{3}(\%)(2) \mathrm{Ba}_{\text {excess }}(\mathrm{ppm})=10^{-6} \times\left[\mathrm{Ba}(\mathrm{ppm}) \times 10^{-6}-0.003125 \times \mathrm{Al}(\%) \times 10^{-2}\right]$

\begin{tabular}{|c|c|c|c|c|c|c|c|c|c|c|c|c|}
\hline $\begin{array}{l}\text { Sediment } \\
\text { depth }\end{array}$ & $\mathrm{CaCO}_{3}$ & TOC & $\mathrm{TS}$ & ${ }^{14} \mathrm{C}$-age & $\mathrm{CaO}$ & $\mathrm{Al}_{2} \mathrm{O}_{3}$ & $\mathrm{SiO}_{2}$ & $\mathrm{Fe}$ & $\mathrm{Zn}$ & $\mathrm{SiO}_{2}$ excess & $\mathrm{Ba}$ excess & Remarks \\
\hline$(\mathrm{cm})$ & (\% wt.) & (\% wt.) & (\% wt.) & (ka) & (\% wt.) & (\% wt.) & (\% wt.) & $(\%)$ & (ppm) & (\% wt.) & (ppm wt) & \\
\hline
\end{tabular}

Shaban deep kasten core 17002-2

$\begin{array}{llll}2.5 & 51.7 & 1.1 & 0.7\end{array}$

$8-9$

$\begin{array}{llll}12.5 & 52.2 & 1.1 & 0.6\end{array}$

$\begin{array}{llll}22 & 62.0 & 0.6 & 0.3\end{array}$

$\begin{array}{llll}31 & 39.8 & 2.9 & 2.6\end{array}$

$\begin{array}{llll}35.5 & 40.9 & 1.0 & 0.4\end{array}$

$\begin{array}{llll}41-43 & & & \\ 44 & 10.6 & 1.4 & 0.5\end{array}$

$\begin{array}{rrrr}44 & 10.6 & 1.4 & 0.5 \\ 48 & 3.9 & 0.4 & 0.5\end{array}$

$\begin{array}{rrrr}52 & 70.1 & 0.3 & 0.2\end{array}$

$\begin{array}{llll}58 & 60.1 & 0.5 & 0.3\end{array}$

$\begin{array}{llll}67 & 67.9 & 0.4 & 0.2\end{array}$

$\begin{array}{llll}75 & 56.7 & 0.8 & 0.5\end{array}$

$\begin{array}{llll}91 & 66.8 & 0.5 & 0.2\end{array}$

$\begin{array}{llll}104 & 60.5 & 0.6 & 0.2\end{array}$

$\begin{array}{llll}127 & 60.1 & 0.6 & 0.2\end{array}$

$\begin{array}{llll}151.5 & 57.6 & 0.6 & 0.3\end{array}$

$\begin{array}{llll}156.5 & 65.6 & 0.8 & 0.7\end{array}$

$\begin{array}{llll}162.5 & 77.7 & 0.3 & 0.2\end{array}$

$\begin{array}{llll}166 & 11.3 & 1.4 & 0.3\end{array}$

$\begin{array}{llll}180 & 52.7 & 0.8 & 0.5\end{array}$

$\begin{array}{llll}196.5 & 16.0 & 2.7 & 0.2\end{array}$

$\begin{array}{llll}197 & 28.0 & 2.4 & 0.2\end{array}$

$\begin{array}{llll}197.5 & 19.7 & 2.7 & 0.7\end{array}$

$\begin{array}{llll}199.5 & 39.9 & 2.3 & 0.9\end{array}$

$\begin{array}{llll}201 & 46.0 & 2.6 & 3.9\end{array}$

202-203

$\begin{array}{llll}202.5 & 36.8 & 4.1 & 1.0\end{array}$

$204 \quad 35.9 \quad 3.2 \quad 1.4$

$207 \quad 52.0 \quad 1.1 \quad 0.5$

$\begin{array}{llll}224.5 & 50.6 & 1.2 & 0.6\end{array}$

$\begin{array}{llll}243.5 & 50.6 & 1.6 & 0.8\end{array}$

$\begin{array}{llll}262 & 44.8 & 1.1 & 8.6\end{array}$

$\begin{array}{llll}279 & 48.6 & 1.3 & 0.6\end{array}$

$\begin{array}{llll}286.5 & 47.3 & 1.6 & 0.8\end{array}$

$\begin{array}{llll}291 & 45.9 & 2.0 & 0.9\end{array}$

$\begin{array}{llll}294 & 39.8 & 1.8 & 9.8\end{array}$

$\begin{array}{llll}297 & 47.4 & 2.2 & 1.2\end{array}$

$\begin{array}{llll}305 & 19.3 & 2.1 & 1.2\end{array}$

$\begin{array}{llll}307 & 51.4 & 0.7 & 0.1\end{array}$

$\begin{array}{llll}309 & 0.7 & 2.5 & 1.1\end{array}$

$\begin{array}{llll}313.5 & 6.5 & 2.7 & 2.9\end{array}$

$\begin{array}{llll}314.5 & 10.2 & 1.8 & 0.5\end{array}$

$\begin{array}{llll}315 & 6.0 & 3.9 & 5.8\end{array}$

$\begin{array}{llll}316.5 & 34.5 & 2.4 & 1.4\end{array}$

$\begin{array}{llll}319.5 & 0.0 & & \\ 322 & 6.9 & 4.1 & 6.3\end{array}$

$\begin{array}{llll}324 & 1.0 & 3.6 & 3.0\end{array}$

$325-326$

$\begin{array}{llll}325.5 & 0.0 & 8.4 & 10.4\end{array}$

$\begin{array}{llll}328.5 & 2.8 & 5.8 & 11.2\end{array}$

12.45

$\begin{array}{lllllll}26.1 & 6.4 & 26.9 & 2.8 & 181 & 4.3 & 37\end{array}$

11.71

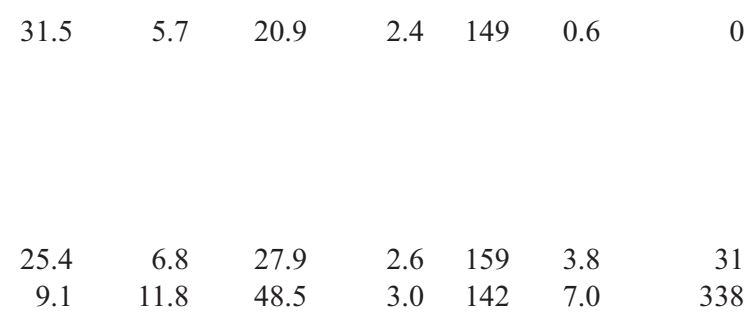

Laminated sapropel

10.24

$\begin{array}{lllllll}18.6 & 6.0 & 33.8 & 2.6 & 494 & 12.5 & 310\end{array}$

Reworked calcareous mud with turbiditic sequences

Laminated sapropel intercalated with lithified carbonate layers 
Table 1 (continued)

\begin{tabular}{|c|c|c|c|c|c|c|c|c|c|c|c|c|}
\hline $\begin{array}{l}\text { Sediment } \\
\text { depth }\end{array}$ & $\mathrm{CaCO}_{3}$ & TOC & $\mathrm{TS}$ & ${ }^{14} \mathrm{C}$-age & $\mathrm{CaO}$ & $\mathrm{Al}_{2} \mathrm{O}_{3}$ & $\mathrm{SiO}_{2}$ & $\mathrm{Fe}$ & $\mathrm{Zn}$ & $\mathrm{SiO}_{2}$ excess & $\mathrm{Ba}$ excess & Remarks \\
\hline$(\mathrm{cm})$ & (\% wt.) & (\% wt.) & (\% wt.) & (ka) & (\% wt.) & (\% wt.) & (\% wt.) & $(\%)$ & (ppm) & (\% wt.) & (ppm wt) & \\
\hline \multicolumn{13}{|c|}{ Shaban deep kasten core $17002-2$} \\
\hline 330 & 0.0 & 3.2 & 4.8 & & & & & & & & & \\
\hline 332 & 21.4 & 2.3 & 12.1 & & & & & & & & & \\
\hline 338 & 64.4 & 2.4 & 1.2 & & 15.4 & 3.5 & 17.4 & 1.7 & 130 & 5.1 & 108 & \\
\hline 339 & 5.9 & 4.6 & 17.0 & & & & & & & & & \\
\hline 339.5 & 45.5 & 4.5 & 9.0 & & & & & & & & & \\
\hline 340 & 9.6 & 5.6 & 7.7 & & & & & & & & & \\
\hline 340.5 & 53.7 & 3.6 & 4.6 & & & & & & & & & \\
\hline 342 & 49.6 & 2.8 & 4.4 & & 1.8 & 5.7 & 58.7 & 4.1 & 207 & 38.5 & 789 & \\
\hline 345.5 & 1.8 & 6.0 & 4.2 & & & & & & & & & \\
\hline 350.5 & 2.1 & 7.2 & 3.2 & & 1.7 & 5.6 & 62.8 & 3.3 & 180 & 43.2 & 831 & \\
\hline 353 & 3.8 & 4.8 & 2.1 & & & & & & & & & \\
\hline 357.5 & 3.2 & 4.9 & 16.9 & & & & & & & & & \\
\hline 359 & 7.0 & 4.7 & 3.2 & & & & & & & & & \\
\hline 359.5 & 54.2 & 2.8 & 1.0 & & & & & & & & & \\
\hline 360.5 & 1.3 & 6.1 & 2.2 & & 1.7 & 6.1 & 55.5 & 8.2 & 308 & 33.9 & 765 & \\
\hline 363.5 & 10.0 & 8.0 & 3.7 & & & & & & & & & \\
\hline 365 & 3.3 & 6.4 & 2.1 & & & & & & & & & \\
\hline 367.5 & 42.0 & 2.8 & 4.0 & & & & & & & & & \\
\hline 370 & 36.4 & 3.4 & 3.5 & & 19.7 & 6.9 & 33.6 & 4.0 & 302 & 9.2 & 243 & \\
\hline 372 & 2.3 & 5.5 & 7.9 & & & & & & & & & \\
\hline $374-375$ & & & & 12.75 & & & & & & & & \\
\hline 377 & 3.1 & 5.1 & 10.2 & & 1.9 & 5.7 & 50.6 & 9.2 & 419 & 30.6 & 559 & \\
\hline 378.5 & 3.0 & 3.5 & 14.8 & & 2.0 & 5.1 & 50.6 & 13.2 & 272 & 32.7 & 298 & \\
\hline 379.5 & 3.7 & 2.4 & 18.7 & & & & & & & & & \\
\hline 380.5 & 4.0 & 2.6 & 20.5 & & 2.1 & 3.5 & 46.7 & 16.3 & 318 & 34.5 & 194 & \\
\hline 383 & 16.1 & 2.8 & 8.3 & & 9.0 & 5.3 & 49.0 & 7.4 & 223 & 30.4 & 234 & \\
\hline 386 & 26.9 & 2.0 & 3.5 & & & & & & & & & \\
\hline 388.5 & 7.1 & 1.1 & 4.6 & & & & & & & & & \\
\hline 391 & 12.0 & 1.7 & 6.7 & & 6.7 & 5.2 & 57.2 & 6.5 & 173 & 38.8 & 124 & \\
\hline 392.5 & 15.6 & 1.1 & 0.3 & & 7.9 & 4.1 & 67.3 & 1.2 & 114 & 53.0 & 110 & \\
\hline 395.5 & 47.7 & 0.6 & 0.4 & & 23.3 & 6.3 & 34.2 & 2.2 & 144 & 11.9 & 38 & \\
\hline 398.00 & 12.7 & 1.4 & 1.4 & & & & & & & & & \\
\hline 401.5 & 16.2 & 1.2 & 0.9 & & & & & & & & & \\
\hline 403.5 & 23.2 & 0.5 & 0.2 & & & & & & & & & Calcareous mud \\
\hline 421 & 45.3 & 0.8 & 0.2 & & & & & & & & & (turbiditic sediment) \\
\hline 440.5 & 40.8 & 0.8 & 1.5 & & & & & & & & & \\
\hline 458.5 & 43.9 & 0.7 & 0.2 & & & & & & & & & \\
\hline 462 & 3.2 & 1.2 & 0.2 & & 1.4 & 6.5 & 74.3 & 1.4 & 99 & 51.5 & 110 & \\
\hline $464-465$ & & & & 13.60 & & & & & & & & Laminated diatomaceous \\
\hline 469 & 5.1 & 1.1 & 0.1 & & & & & & & & & ooze with few \\
\hline 471.5 & 6.8 & 1.6 & 0.4 & & & & & & & & & intercalated carbonate \\
\hline 475.5 & 20.3 & 0.8 & 0.3 & & & & & & & & & layers \\
\hline 480.5 & 8.3 & 1.5 & 0.4 & & 3.1 & 7.8 & 66.3 & 2.1 & 184 & 38.8 & 107 & \\
\hline 487.5 & 8.6 & 1.7 & 0.6 & & & & & & & & & \\
\hline 494.5 & 4.3 & 0.9 & 0.1 & & & & & & & & & \\
\hline 498 & 8.0 & 1.3 & 0.5 & & & & & & & & & \\
\hline 502.5 & 5.0 & 1.2 & 0.3 & & 1.8 & 6.4 & 73.3 & 1.6 & 88 & 51.0 & 91 & \\
\hline 512 & 4.2 & 1.1 & 8.7 & & & & & & & & & \\
\hline 522 & 1.7 & 1.2 & 25.3 & & & & & & & & & \\
\hline 529 & 4.2 & 1.0 & 0.3 & & & & & & & & & \\
\hline 541.5 & 4.2 & 1.1 & 0.4 & & & & & & & & & \\
\hline $546-548$ & & & & 14.71 & & & & & & & & \\
\hline 554 & 6.6 & 1.3 & 1.2 & & 2.8 & 5.1 & 72.0 & 2.1 & 163 & 54.1 & 95 & \\
\hline 564 & 10.2 & 1.5 & 1.9 & & 5.3 & 4.0 & 68.8 & 2.4 & 102 & 54.6 & 112 & \\
\hline 574.5 & 7.2 & 1.5 & 4.6 & & & & & & & & & \\
\hline
\end{tabular}


Table 1 (continued)

\begin{tabular}{|c|c|c|c|c|c|c|c|c|c|c|c|c|}
\hline $\begin{array}{l}\text { Sediment } \\
\text { depth }\end{array}$ & $\mathrm{CaCO}_{3}$ & TOC & TS & ${ }^{14} \mathrm{C}$-age & $\mathrm{CaO}$ & $\mathrm{Al}_{2} \mathrm{O}_{3}$ & $\mathrm{SiO}_{2}$ & $\mathrm{Fe}$ & $\mathrm{Zn}$ & $\mathrm{SiO}_{2}$ excess & $\mathrm{Ba}$ excess & Remarks \\
\hline$(\mathrm{cm})$ & (\% wt.) & (\% wt.) & (\% wt.) & (ka) & (\% wt.) & (\% wt.) & (\% wt.) & $(\%)$ & $(\mathrm{ppm})$ & (\% wt.) & (ppm wt) & \\
\hline \multicolumn{13}{|c|}{ Shaban deep kasten core 17002-2 } \\
\hline 588 & 35.3 & 1.3 & 0.7 & & & & & & & & & \multirow{31}{*}{$\begin{array}{l}\text { Mixed diatomaceous } \\
\text { ooze and calcareous mud } \\
\text { (reworked sediment) }\end{array}$} \\
\hline $609-610$ & & & & 15.68 & & & & & & & & \\
\hline 610 & 14.5 & 1.4 & 5.4 & & & & & & & & & \\
\hline 631 & 11.4 & 1.5 & 4.8 & & & & & & & & & \\
\hline 652 & 29.0 & 1.4 & 1.3 & & & & & & & & & \\
\hline $658-660$ & & & & 16.11 & & & & & & & & \\
\hline 660.5 & 20.9 & 1.3 & 1.5 & & & & & & & & & \\
\hline 687.5 & 17.3 & 1.9 & 0.1 & & & & & & & & & \\
\hline 700 & 16.4 & 1.7 & 5.3 & & & & & & & & & \\
\hline 706 & 17.2 & 1.4 & 4.1 & & & & & & & & & \\
\hline 728.5 & 43.6 & 1.0 & 0.8 & & & & & & & & & \\
\hline 730 & 16.0 & 0.7 & 0.9 & & & & & & & & & \\
\hline 732 & 8.1 & 0.6 & 0.1 & & & & & & & & & \\
\hline $733-734$ & & & & 18.65 & & & & & & & & \\
\hline 733.5 & 7.2 & 1.8 & 0.4 & & & & & & & & & \\
\hline 734.5 & 4.8 & 0.9 & 0.2 & & & & & & & & & \\
\hline 736.5 & 11.6 & 1.0 & 0.4 & & & & & & & & & \\
\hline 743.5 & 49.9 & 0.7 & 0.3 & & & & & & & & & \\
\hline 750.5 & 25.0 & 0.9 & 1.3 & & & & & & & & & \\
\hline 753.5 & 17.7 & 1.1 & 0.9 & & & & & & & & & \\
\hline 761.5 & 24.8 & 1.2 & 8.0 & & & & & & & & & \\
\hline 771 & 14.8 & 2.3 & 1.5 & & & & & & & & & \\
\hline 774 & 22.0 & 1.2 & 1.5 & & & & & & & & & \\
\hline 778.5 & 9.0 & 1.6 & 0.3 & & & & & & & & & \\
\hline 783 & 24.2 & 0.1 & 0.2 & & & & & & & & & \\
\hline 796.5 & 32.9 & 0.8 & 0.3 & & & & & & & & & \\
\hline 811 & 55.4 & 0.4 & 1.0 & & & & & & & & & \\
\hline 824 & 47.3 & 0.2 & 0.3 & & & & & & & & & \\
\hline 833.5 & 30.2 & 1.2 & 1.4 & & & & & & & & & \\
\hline 844.5 & 21.7 & 1.3 & 2.5 & & & & & & & & & \\
\hline $851-852$ & & & & 21.10 & & & & & & & & \\
\hline \multicolumn{13}{|c|}{ Kebrit deep kasten core 17006-5 } \\
\hline 5 & 61.2 & 1.6 & 5.1 & & 33.1 & 4.0 & 15.7 & 5.5 & 655 & 2.5 & 51 & \multirow{8}{*}{$\begin{array}{l}\text { Calcareous mud with } \\
\text { sandy bottom (turbidite) }\end{array}$} \\
\hline 8.5 & 70.7 & 1.2 & 2.8 & & & & & & & & & \\
\hline 14 & 54.0 & 2.6 & 4.2 & & & & & & & & & \\
\hline 16.5 & 52.4 & 2.6 & 4.0 & & & & & & & & & \\
\hline 20 & 51.4 & 2.6 & 3.8 & & & & & & & & & \\
\hline 26.5 & 55.5 & 2.5 & 3.8 & & & & & & & & & \\
\hline 34 & 56.8 & 2.3 & 3.5 & & & & & & & & & \\
\hline 41 & 55.5 & 2.3 & 3.6 & & & & & & & & & \\
\hline 45 & 56.1 & 2.3 & 3.8 & & 29.6 & 5.0 & 19.5 & 4.3 & 479 & 3.1 & 65 & \\
\hline 48 & 76.2 & 0.5 & 2.4 & & & & & & & & & \\
\hline 49 & 62.2 & 1.7 & 3.7 & & & & & & & & & \\
\hline 50 & 68.1 & 1.2 & 1.7 & & & & & & & & & \\
\hline 50.5 & 66.3 & 1.5 & 2.3 & & 34.5 & 4.3 & 16.1 & 2.7 & 201 & 1.8 & 31 & \multirow{9}{*}{$\begin{array}{l}\text { Greenish laminated } \\
\text { mud with light gray } \\
\text { calcareous laminae }\end{array}$} \\
\hline 51.5 & 52.0 & 4.1 & 4.2 & & 28.9 & 4.7 & 20.5 & 4.0 & 470 & 5.0 & 82 & \\
\hline 52 & 67.6 & 1.2 & 1.7 & & & & & & & & & \\
\hline 53 & 55.7 & 3.5 & 3.7 & & 30.1 & 4.7 & 19.4 & 3.7 & 424 & 4.0 & 65 & \\
\hline 53.5 & 55.7 & 3.2 & 4.0 & & & & & & & & & \\
\hline 54 & 65.1 & 2.0 & 2.8 & & & & & & & & & \\
\hline 54.4 & 56.2 & 2.2 & 3.0 & & & & & & & & & \\
\hline 55 & 49.8 & 2.0 & 4.6 & & & & & & & & & \\
\hline 56 & 68.9 & 0.6 & 1.1 & & 36.7 & 4.3 & 15.1 & 2.2 & 151 & 0.9 & 19 & \\
\hline
\end{tabular}


Table 1 (continued)

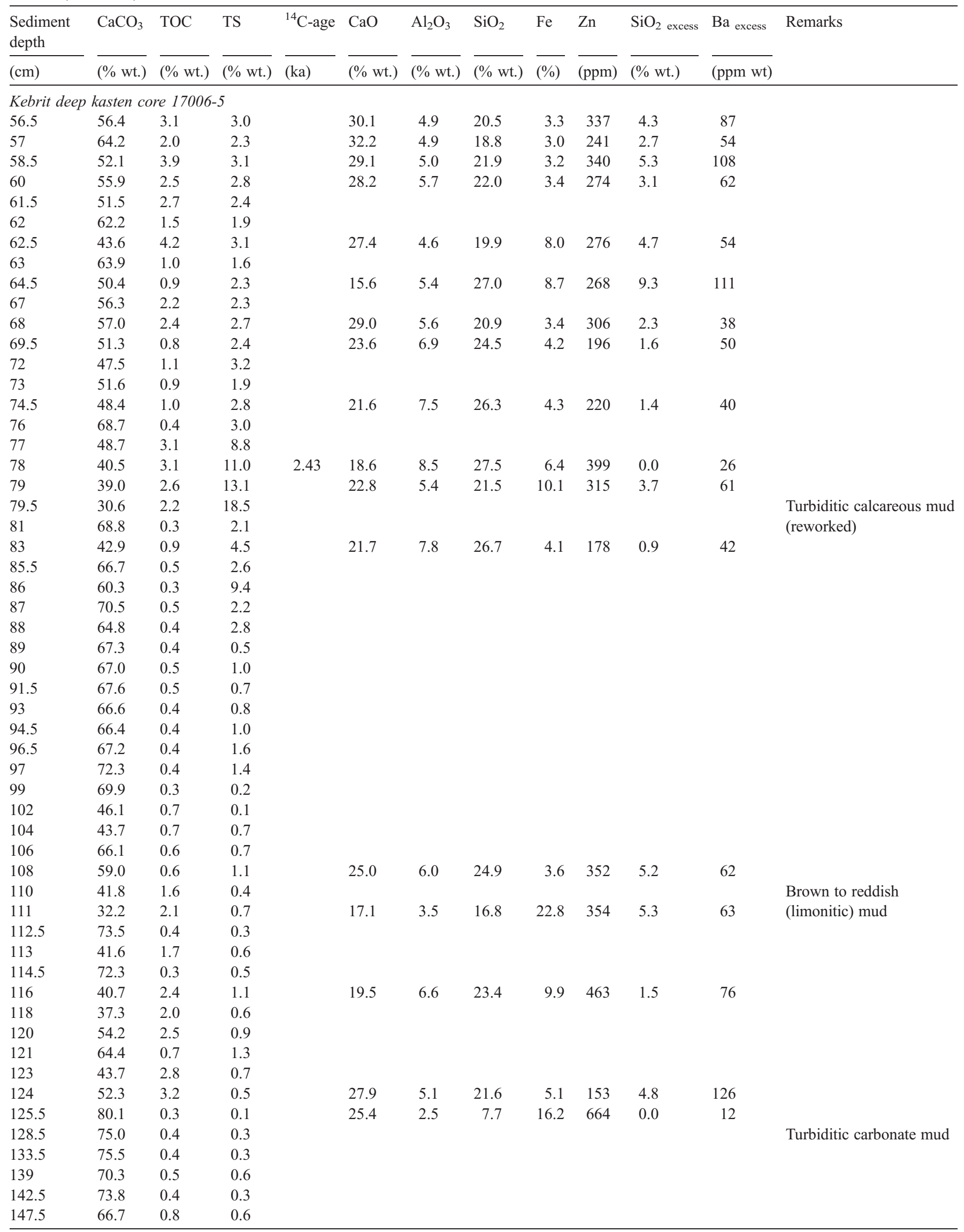


Table 1 (continued)

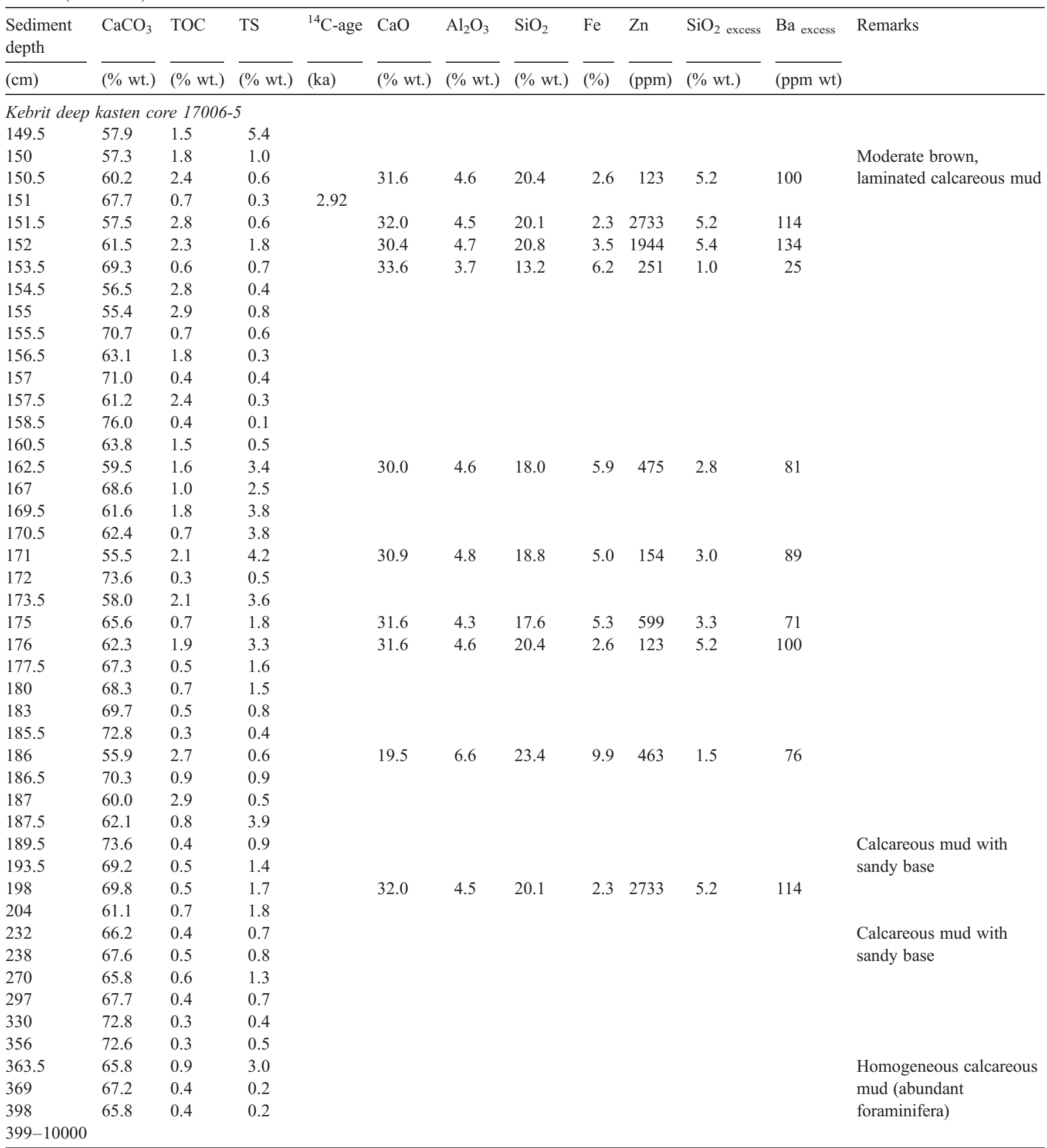

TOC: Total Organic matter.

TS: Total Sulfur.

\subsection{Extractable organic substances}

One to $6 \mathrm{~g}$ (depending on the organic carbon content) of sediment, and $0.1-0.5 \mathrm{~g}$ of filtered material sampled from the brine-sea water interface were taken for quantitative extraction of soluble organic matter (lipid fraction). A Soxtec apparatus was used with $\mathrm{CH}_{2} \mathrm{Cl}_{2}-$ $\mathrm{CH}_{3} \mathrm{OH}$ mixture (95: 5) boiling at $65{ }^{\circ} \mathrm{C}$ for $2 \mathrm{~h}$ and 


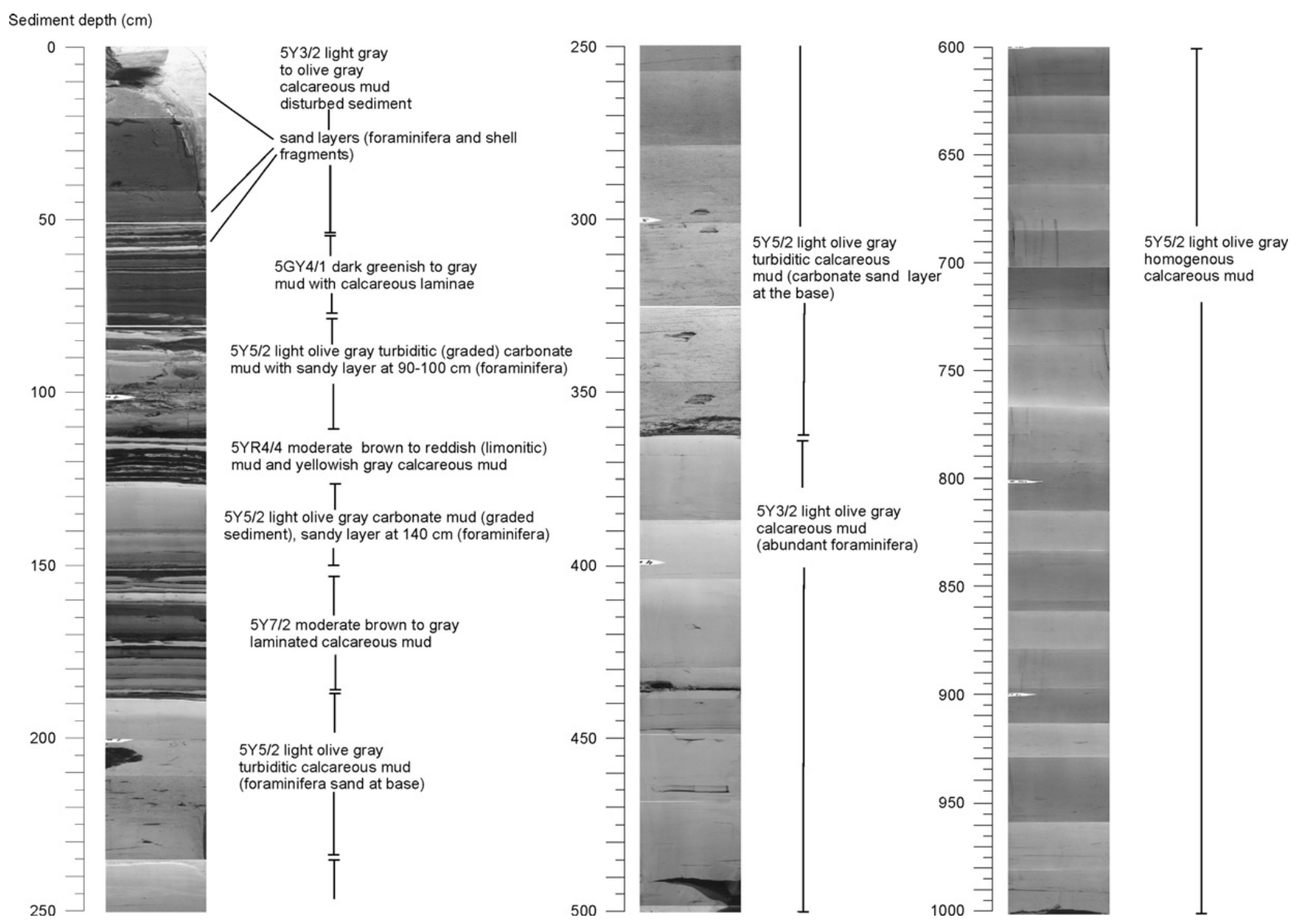

Fig. 3. Major sediment types of sediment core KC 17006-5 (Kebrit deep). Sediment below $200 \mathrm{~cm}$ consists of light olive gray (5Y5/2), homogenous carbonate mud. The color code is given after the Rock Color Chart (1991).

rinsing for $5 \mathrm{~h}$ at $95^{\circ} \mathrm{C}$. The total extract was fractionated over silica gel using iso-hexane for the elution of the aliphatic fraction, and $\mathrm{CH}_{2} \mathrm{Cl}_{2}: \mathrm{CH}_{3} \mathrm{OH}$ (3:1) for the aromatic hydrocarbons and the polar fraction, containing $\mathrm{N}, \mathrm{S}$, and $\mathrm{O}$ in the molecules. $\mathrm{KOH}$-coated $\mathrm{SiO}_{2}$ was used to split the (aromatic and) polar fraction into three groups of different polarity, using $\mathrm{CH}_{2} \mathrm{Cl}_{2}$ (ketones), $\mathrm{CH}_{2} \mathrm{Cl}_{2}-\mathrm{CH}_{3} \mathrm{OH}$ (9:1, alcohols), and $\mathrm{CH}_{2} \mathrm{Cl}_{2}-\mathrm{HCOOH}$ (carboxylic acids). By this method no complete separation between ketones and alcohols could be achieved. Besides trisnorhopanone and alkenones, dinosterol, homohopanol, and bishomohopanol may be found in the ketone fraction. Therefore, the relevant compounds ketones and alcohols - were identified in both fractions and quantified by their peak areas. Measurements on the aliphatic, keto, alcohol, and acid fraction have been performed simultaneously with a HP 6890 (GC-FID) coupled with a Finnigan MAT 95S (GC-MS; columns: DB-5 - $30 \mathrm{~m} \times 0.25 \mathrm{~mm} \times 0.25 \mu \mathrm{m}$; mass range $50-$ $600 \mathrm{amu})$. The ketones and alcohols were derivatized with $N$-methyl- $N$-(trimethylsilyl)-trifluoroacetamid
(MSTFA), the carboxylic acids with dimethylformamiddimethylacetat (DMF-DMA). Analytical results were quantified by using 4-cholesten-3-one (NSO fractions) and squalane (aliphatic fractions) as internal standards.

\subsection{Kerogen preparation and Rock Eval pyrolysis}

Up to $0.5 \mathrm{~g}$ residues from organic extraction (see above) were repeatedly treated with $6 \mathrm{M} \mathrm{HCl}$ at $50{ }^{\circ} \mathrm{C}$ and washed with distilled water in order to remove any carbonate materials present in the samples. Silicates were removed by adding HF $(75 \%)$ and washed with distilled water. After that pyrite was dissolved using concentrated $\mathrm{HCl}$. The kerogen samples were again carefully washed with distilled water and dried at $50{ }^{\circ} \mathrm{C}$ in an oven.

Pyrolysis data (Hydrogen Index) was achieved by analysing the kerogen concentrates with a Rock-Eval-V apparatus (DELSI). Both parameters, $\mathrm{S}_{1}$, the hydrocarbon fraction mobilized at $300{ }^{\circ} \mathrm{C}$ and, $\mathrm{S}_{2}$, hydrocarbons generated through kerogen cracking at $650{ }^{\circ} \mathrm{C}$, are used for kerogen type characterisation (Espitalié et al., 1977). 


\subsection{Organic petrology}

Polished blocks of freeze-dried and ground samples were prepared. Descriptions and semi-quantitative estimates of the microscopically visible organic materials have been made using a Leica DMR microscope in incident normal light and under fluorescence illumination (UV and blue light excitation, barrier filter at $530 \mathrm{~nm}$ ) following routine procedures (Stach et al., 1982; Hufnagel and Porth, 1989). The lower detection limit of the microscopical particles is 0.5 to $1 \mu \mathrm{m}$. If present in sufficient quantities dissolved or very finely dispersed organics of lipidic and/or humic nature were observed by their colors. Semi-quantitative estimates (by vol.\%) of major organic components are based on the assumption: inertinite, huminite, liptinite, bituminite, fecal pellets plus fluorescing radiolarians amount 100. Liptinite is differentiated into alginite and pollen (sporinite). Frequencies of pyrite and the inorganic remains of the major groups of the microfossils are classified by numbers 0 to 5 .

\subsection{Stable carbon isotopes of kerogens and of 22,29,30-trisnorhopan-21-one (TNH)}

Between 5 and $20 \mathrm{mg}$ of pre-concentrated (see above) kerogen samples were combusted (as triplicates) at $1000{ }^{\circ} \mathrm{C}$ in a $\mathrm{CuO}$-oven. The produced $\mathrm{CO}_{2}$ was measured for its carbon isotope composition using a Finnigan MAT 251 mass spectrometer.

The compound-specific carbon isotopic composition of 22,29,30-trisnorhopan-21-one was measured by GCirmMS (Freeman et al., 1990) with a Finnigan Trace-GC coupled to a Thermofinnigan Delta plus mass spectrometer via a GC/C III combustion transfer line. The compounds of interest in the ketone fraction were separated on a DB-5 column ( $30 \mathrm{~m}, 0.32 \mathrm{~mm}, 0.25 \mu \mathrm{m})$, the combustion reactor in the GC/C III system was set at $850{ }^{\circ} \mathrm{C}$. The reproducibility of triplicate analysis was better than $\pm 0.5 \%$ for 22,29,30-trisnorhopan-21-one.

All $\delta^{13} \mathrm{C}$ values are given as deviation from the VPDB standard.

\subsection{Major and trace elements, XRF analysis}

One gram of powdered sediment samples was glowed at $1030{ }^{\circ} \mathrm{C}$ within a porcelain vessel in order to remove any volatiles and determine the loss on ignition (LOI). The samples, mixed with $5 \mathrm{~g}$ Li-metaborate and $25 \mathrm{mg}$ Li-bromide, were melted at $1500{ }^{\circ} \mathrm{C}(20 \mathrm{~min})$ within platinum vessels and were then homogenized. Measurements of major and trace elements were performed using
Chromium-/Rhodium tube within the XRF-spectrometer (PW 1480 and PW 2400). Standardisation is based on international rock standards. Precision is within $1-2 \%$ for major elements and $5-10 \%$ for trace elements, respectively.

The $\mathrm{Ba}_{\text {excess }}$ values were estimated according to the method described by Kasten et al. (2001). Based on the measured $\mathrm{Ba}$ and $\mathrm{Al}$ data a regional $\mathrm{Ba} / \mathrm{Al}$-background ratio of 0.003125 could be determined and the $B a_{\text {excess }}$ values were then calculated by the deviation of the measured Ba-content from the regional Ba-value corresponding to the measured $\mathrm{Al}$-content. In a similar calculation a regional average ratio of $3.19\left(\mathrm{SiO}_{2} / \mathrm{Al}_{2} \mathrm{O}_{3}\right)$ was assumed for detrital sediment input. This ratio is comparable to the average value of 3.25 determined for detrital sediment in the central graben of the Red Sea (e.g. Bischoff, 1969). The $\mathrm{SiO}_{2}$ excess values were calculated by the deviation of the measured $\mathrm{SiO}_{2}$ content from the regional $\mathrm{SiO}_{2}$-value (calculated using the measured $\mathrm{Al}_{2} \mathrm{O}_{3}$-content).

\subsection{Sediment dating (by accelerator mass spectrometry-AMS)}

In the Shaban and Kebrit deeps carbonate turbidites are frequently indicated by (carbonate) sand layers and vertical graded sediments. This is probably one reason that former conventional ${ }^{14} \mathrm{C}$-dating experiments on sedimentary carbonate of core $378 \mathrm{KL}$ from the southern subbasin of the Shaban deep gave no meaningful results (Stoffers et al., 1990). During the present study we measured the ${ }^{14} \mathrm{C}$-content of organic matter from 13 subsamples of two sediment cores in the Shaban- and Kebrit deeps (Table 1). In accordance to the previous findings for the Shaban deep ${ }^{14} \mathrm{C}$-dating of carbonate-rich sediments revealed no meaningful stratigraphic information (compare result section). Hence, we may assume that many (if not all) of the analysed carbonate-rich horizons in the Shaban deep are redeposited sediments (turbidites). Hence, we concentrated on ${ }^{14} \mathrm{C}$-dating of organic matter embedded exclusively in carbonate-poor laminated sediments with a high organic content.

Sample preparation for AMS dating followed the routine procedure of the Leibniz Laboratory at Kiel University (Grootes et al., 2004). After a microscopic check on sample purity the sediments were treated with $1 \% \mathrm{HCl}, 1 \% \mathrm{NaOH}$ at $60{ }^{\circ} \mathrm{C}$ and again $1 \% \mathrm{HCl}$. Combustion was performed at $900{ }^{\circ} \mathrm{C}$ within a quartz ampoule containing $\mathrm{CuO}$ and silver wool. The evolved $\mathrm{CO}_{2}$ was reduced to graphite (using $\mathrm{H}_{2}$ at $600{ }^{\circ} \mathrm{C}$ in presence of an Fe-catalyst). After that the Fe-graphite 
mixture was pressed into a sample container for AMS measurement. The ${ }^{14} \mathrm{C}$-concentrations were determined by comparing simultaneously measured ${ }^{14} \mathrm{C},{ }^{13} \mathrm{C}$ and ${ }^{12} \mathrm{C}$ contents with those of the $\mathrm{CO}_{2}$ standard (oxalic acid II) and zero-effect sample (coal). The conventional ${ }^{14} \mathrm{C}$ age was calculated after Stuiver and Polach (1977) including correction of isotope fractionation by the ${ }^{13} \mathrm{C} /{ }^{12} \mathrm{C}$ ratios. Given uncertainty includes counting statistics, stability of AMS and zero-effect.

\section{Results and discussion}

\subsection{Sediment types defined by composition}

\subsubsection{Carbonate sediments}

The $\mathrm{CaCO}_{3}$-content of sediment core 17002-2 in the southern Shaban deep is extremely variable between $<0.2$ and $78 \%$ with the high values usually occurring in the upper $300 \mathrm{~cm}$ of the core (Table 1). Various several $\mathrm{cm}$ large olive gray and olive black-colored sediment inclusions/lumps within light-colored carbonateenriched host sediment (at core depths 0-80, 240-260 and 420-460 cm; Fig. 2) indicate substantial sediment reworking. Core 17006-5 from the Kebrit deep revealed more uniform and at an average higher carbonate values between 30 and $80 \%$ (Table 1). Sediment cores from both deeps contain numerous variably thick layers enriched in foraminifera and pteropods and sediment grading can be observed (Hemleben et al., 1996a; see core descriptions in Figs. 2 and 3). It has been mentioned before that dating experiments of those carbonate-rich sediments revealed no meaningful sediment ages (Stoffers et al., 1990; upper $202 \mathrm{~cm}$ of core 17002-2, Table 1). Moreover, slow settling of single carbonate particles through acidic brines ( $\mathrm{pH} 5.5-6.0)$ can cause complete carbonate dissolution (Schmidt et al., 2006). Rapid sedimentation of carbonate shells by turbidites, however, prevents significant carbonate dissolution (Schmidt et al., 2006). Although sediment radiographs were not prepared during this study, we assume that most carbonaceous sediments from the Kebrit- and Shaban deeps were deposited as turbidites (Hemleben et al., 1996a; Figs. 2 and 3). Hence, the significance of carbonaceous sediments within Red Sea deeps for reconstructing the paleodepositional environment seems to be low. In contrast, carbonate shells within (carbonate-poor) laminated sediments are often incorporated within fecal pellets or pellicles (Erba et al., 1987). Accordingly, for Shaban sediments with low $\left(<10 \% \mathrm{CaCO}_{3}\right)$ carbonate contents a positive correlation exists between the percentages of fecal pellets and the carbonate content (Tables 1 and 2). When these organic particles settle through the acidic brine within the deeps the enclosed carbonate shells remain undissolved. Then the presence of carbonate fossils may well be discussed in terms of their paleoceanographic implications (Seeberg-Elverfeldt et al., 2004b, 2005).

The major elemental composition of Al-, Ca-, and $\mathrm{Si}$ of sediments from the Kebrit- and Shaban deeps allows the characterisation of major sediment types. For instance, the $\mathrm{Al}_{2} \mathrm{O}_{3}$, and $\mathrm{CaO}$ concentrations of Shabanand Kebrit deep sediments (Table 1) compare well with the average element composition given for the "normal" Red Sea sediment facies (Bäcker, 1976; Scholten et al., 2000). Furthermore, the $\mathrm{Al}_{2} \mathrm{O}_{3}, \mathrm{CaO}$, and $\mathrm{SiO}_{2}$ concentrations of Kebrit deep sediments plot close to a theoretical line in Fig. 4, which connects two assumed sediment endmembers: average pelagic clay and deepsea carbonate (McLennan and Murray, 1999). Hence, based on major element analyses variable pelagic clay/ carbonate mixtures are indicated for the Kebrit deep. Relatively high $\mathrm{CaO}$ concentrations between 25.4 and 31.5 wt. \%, representing carbonate-rich, probably turbiditic sediments (see above), were also measured for the upper part $(12.5-180 \mathrm{~cm})$ of core $17002-2$ from the Shaban deep.

\subsubsection{Siliceous ooze}

Whereas sediment samples from the Kebrit deep fall on (or very close to) the mixing line between deep-sea carbonate and pelagic clay, most Shaban deep sediment samples plot off the mixing line as the samples are enriched in $\mathrm{Si}$ (Fig. 4). The reason is that the lower part (below $309 \mathrm{~cm}$ ) of core 17002-2, where most of the samples were taken, contains sapropel sediment and siliceous ooze (Table 1; Fig. 2). The predominance of siliceous sediments in the Shaban core can also be recognised by calculating the $\mathrm{Si}_{\text {excess }}$ values (Table 1 ). Diatomaceous sediments are the major sediment type of the lower part (305-852 cm) of core 17002-2 from the Shaban deep (note that core section $755 \mathrm{~cm}$ to $850 \mathrm{~cm}$ is disturbed by coring or sediment reworking and carbonate-rich turbidites are present; Hemleben et al., 1996a; Fig. 2). According to our ${ }^{14} \mathrm{C}$-dating results on organic material the diatomaceous sediments of core 17002-2 were probably deposited from the last glacial maximum (LGM, 22-19 ka) on during early sea level rise through the cooling phase Heinrich Event 1 and the Bolling-Allerod to the Younger Dryas (13.1-11.7 ka). For that time period changing seawater conditions from an oligotrophic stratified to a fertile stratified water column are assumed (Legge et al., 2006).

Siliceous microplankton in surface sediments of the northern Red Sea including the Shaban deep was 
Table 2

Organic-petrographical observations of sediment cores 17002-2 (Shaban deep) and 17006-5 (Kebrit deep) applying the classification after Stach et al., $1982(1=$ absent or very low, $2=$ few, $3=$ mean, $4=$ frequent, 5 =predominant)

\begin{tabular}{|c|c|c|c|c|c|c|c|c|c|c|c|c|c|c|}
\hline \multirow{2}{*}{$\begin{array}{l}\text { Sediment } \\
\text { depth }\end{array}$} & \multirow{2}{*}{$\begin{array}{l}\text { Organic } \\
\text { matter }\end{array}$} & \multirow[t]{2}{*}{ TOC } & \multirow[t]{2}{*}{ Liptinite } & \multirow[t]{2}{*}{ Bituminite } & \multirow[t]{2}{*}{ Inertinite } & \multirow[t]{2}{*}{ Humite } & \multirow{2}{*}{$\begin{array}{l}\text { Fecal } \\
\text { Pellets }\end{array}$} & \multirow[t]{2}{*}{ Zooclastics } & \multicolumn{2}{|l|}{ Liptinite } & \multirow{3}{*}{$\begin{array}{l}\text { Foraminifera } \\
(1-5)\end{array}$} & \multirow{3}{*}{$\begin{array}{l}\text { Diatoms } \\
\overline{(1-5)}\end{array}$} & \multirow{3}{*}{$\begin{array}{l}\text { Spiculae } \\
\frac{(1-5)}{}\end{array}$} & \multirow{3}{*}{$\begin{array}{l}\text { Pyrit } \\
(1-5)\end{array}$} \\
\hline & & & & & & & & & Alginite & Pollens & & & & \\
\hline$(\mathrm{cm})$ & $(1-5)$ & (\% wt.) & $(\%$ vol. $)$ & & & & & & (\% vol.) & & & & & \\
\hline \multicolumn{15}{|c|}{ Shaban deep kasten core 17002-2 } \\
\hline 2.5 & 3.0 & 1.1 & 1 & 37 & 2 & 4 & 56 & 0 & 95 & 5 & 4 & 3.0 & 0.0 & 2.5 \\
\hline 104.0 & 2.0 & 0.6 & 1 & 20 & 2 & 1 & 76 & 0 & 100 & 0 & 3 & 4.0 & 0.0 & 2.0 \\
\hline 180.0 & 3.0 & 0.8 & 3 & 37 & $<1$ & $<1$ & 60 & 0 & 100 & $<1$ & 4 & 3.0 & 0.0 & 2.0 \\
\hline 197.0 & 5.0 & 1.6 & 1 & 5 & 1 & 0 & 93 & $<1$ & 100 & $<1$ & 0 & 1.0 & 0.0 & 1.5 \\
\hline 204.0 & 5.0 & 3.2 & 0 & 29 & 1 & 0 & 70 & 1 & 90 & 0 & 2 & 5.0 & 0.0 & 3.0 \\
\hline 305.0 & 5.0 & 2.1 & 2 & 8 & 1 & 0 & 89 & 0.5 & 100 & 0 & 1 & 5.0 & 0.0 & 1.0 \\
\hline 313.5 & 4.0 & 2.7 & 1 & 14 & 0 & 0 & 85 & $<1$ & 100 & $<1$ & 1 & 5.0 & 0.0 & 3.5 \\
\hline 316.5 & 4.5 & 2.4 & 2 & 43 & $<1$ & 0 & 55 & $<1$ & 100 & 0 & 0 & 2.0 & 0.0 & 2.5 \\
\hline 322.0 & 4.0 & 4.1 & 3 & 25 & 0 & 0 & 72 & $<1$ & 90 & 10 & 0 & 4.5 & 0.0 & 4.5 \\
\hline 325.5 & 4.0 & 8.4 & 25 & 35 & $<1$ & 0 & 40 & $(<1)$ & 100 & $<1$ & 0 & 4.0 & 0.0 & 5.0 \\
\hline 338.0 & 4.0 & 2.4 & 15 & 40 & $<1$ & 0 & 45 & 0 & 100 & 0 & 0 & 4.0 & 0.0 & 3.0 \\
\hline 342.0 & 3.5 & 2.8 & 10 & 30 & 0 & 0 & 60 & 0 & 100 & 0 & 0 & 4.5 & 4.0 & 3.0 \\
\hline 345.5 & 3.0 & 6.0 & 4 & 22 & $<1$ & 0 & 74 & 0 & 100 & 0 & 0 & 3.5 & 4.5 & 2.5 \\
\hline 350.5 & 3.5 & 7.2 & 4 & 15 & 0 & 0 & 81 & 0 & 100 & 0 & 0 & 3.5 & 4.5 & 2.5 \\
\hline 370.0 & 4.0 & 3.4 & 10 & 40 & 0 & 0 & 50 & 0 & 100 & 0 & 1 & 4.5 & 2.0 & 4.0 \\
\hline 372.0 & 4.0 & 5.5 & 2 & 44 & $<1$ & 0 & 54 & 0 & 100 & 0 & 0 & 4.5 & 4.0 & 3.5 \\
\hline 392.5 & 3.0 & 1.1 & 0 & 10 & 0 & 0 & 90 & 0 & 100 & 0 & 0 & 5.0 & 2.0 & 0.5 \\
\hline 395.5 & 2.5 & 0.6 & 0 & 3 & 4 & 0 & 93 & 0 & 100 & 0 & 1 & 4.5 & 0.0 & 1.0 \\
\hline 401.5 & 2.0 & 0.4 & 4 & 7 & 4 & 0 & 85 & 0 & 100 & 0 & 0 & 2.5 & 0.0 & 0.5 \\
\hline 462.0 & 2.5 & 1.2 & 0 & 1 & 2 & 0 & 97 & $(<1)$ & 100 & 0 & 0 & 5.0 & 0.0 & 0.5 \\
\hline 480.5 & 3.0 & 1.5 & 0 & 2 & 1 & 0 & 97 & 0 & 100 & 0 & 0 & 4.5 & 0.0 & 0.5 \\
\hline
\end{tabular}


Table 2 (continued)

\begin{tabular}{|c|c|c|c|c|c|c|c|c|c|c|c|c|c|c|}
\hline \multirow{2}{*}{$\begin{array}{l}\text { Sediment } \\
\text { depth }\end{array}$} & \multirow{2}{*}{$\begin{array}{l}\text { Organic } \\
\text { matter }\end{array}$} & \multirow[t]{2}{*}{ TOC } & \multirow[t]{2}{*}{ Liptinite } & \multirow[t]{2}{*}{ Bituminite } & \multirow[t]{2}{*}{ Inertinite } & \multirow[t]{2}{*}{ Humite } & \multirow{2}{*}{$\begin{array}{l}\text { Fecal } \\
\text { Pellets }\end{array}$} & \multirow[t]{2}{*}{ Zooclastics } & \multicolumn{2}{|l|}{ Liptinite } & \multirow{3}{*}{$\begin{array}{l}\text { Foraminifera } \\
(1-5)\end{array}$} & \multirow{3}{*}{$\begin{array}{l}\text { Diatoms } \\
\overline{(1-5)}\end{array}$} & \multirow{3}{*}{$\begin{array}{l}\text { Spiculae } \\
\frac{(1-5)}{}\end{array}$} & \multirow{3}{*}{$\begin{array}{l}\text { Pyrite } \\
(1-5)\end{array}$} \\
\hline & & & & & & & & & Alginite & Pollens & & & & \\
\hline$(\mathrm{cm})$ & $(1-5)$ & (\% wt.) & (\% vol.) & & & & & & (\% vol.) & & & & & \\
\hline \multicolumn{15}{|c|}{ Shaban deep kasten core $17002-2$} \\
\hline 502.5 & 3.0 & 1.2 & 1 & 4 & 0 & 0 & 95 & 0 & 100 & 0 & 0 & 5.0 & 0.0 & 0.5 \\
\hline 522.0 & 0.5 & 0.5 & 0 & 40 & 0 & 0 & 60 & 0 & 100 & 0 & 0 & 4.0 & 0.0 & 4.0 \\
\hline 554.0 & 3.0 & 1.3 & 0 & 7 & 0 & 0 & 93 & 0 & 100 & 0 & 0 & 5.0 & 0.0 & 2.0 \\
\hline 564.0 & 3.0 & 1.5 & 0 & 10 & 0 & 0 & 90 & 0 & 100 & 0 & 0 & 5.0 & 0.0 & 1.0 \\
\hline 728.5 & 1.0 & 0.6 & 1 & 88 & 6 & 0 & 5 & 0 & 100 & 0 & 1 & 0.0 & 0.0 & 1.0 \\
\hline \multicolumn{15}{|c|}{ Kebrit deep kasten core 17006-5 } \\
\hline 5.0 & 4.0 & 1.6 & 1 & 15 & $<1$ & 0 & 81 & 3 & 90 & 10 & 3 & 0.0 & 0.0 & 5.0 \\
\hline 45.0 & 4.5 & 2.3 & 0 & 15 & $<1$ & 0 & 84 & 1 & 100 & 0 & 4 & 3.0 & 0.0 & 5.0 \\
\hline 50.0 & 4.0 & 1.2 & 0 & 10 & $<1$ & 0 & 90 & 0 & 95 & 5 & 3 & 0.0 & 0.0 & 4.0 \\
\hline 51.5 & 5.0 & 4.1 & 0 & 20 & 0 & 0 & 80 & $<1$ & 100 & 0 & 3 & 3.0 & 0.0 & 5.0 \\
\hline 58.5 & 5.0 & 3.9 & 1 & 5 & 1 & $<1$ & 93 & $<1$ & 100 & 0 & 4 & 3.0 & 0.0 & 5.0 \\
\hline 60.0 & 4.5 & 2.5 & 0 & 8 & 1 & 0 & 91 & 0 & 80 & 20 & 4 & 3.0 & 0.0 & 5.0 \\
\hline 62.5 & 5.0 & 4.2 & 0 & 5 & 0 & 0 & 95 & 0 & 100 & 0 & 4 & 3.0 & 0.0 & 5.0 \\
\hline 69.5 & 3.5 & 0.8 & 2 & 39 & 6 & $<1$ & 53 & 0 & 100 & 0 & 3 & 3.0 & 0.0 & 3.5 \\
\hline 74.5 & 3.5 & 1.0 & 1 & 47 & 12 & $<1$ & 40 & 0 & 100 & 0 & 3 & 3.0 & 0.0 & 4.0 \\
\hline 78.0 & 4.5 & 3.1 & 0 & 20 & 1 & 0 & 79 & $<1$ & 100 & 0 & 3 & 3.0 & 0.0 & 5.0 \\
\hline 79.0 & 4.5 & 2.6 & 0 & 18 & 0 & 0 & 82 & $<1$ & 100 & 0 & 3 & 3.0 & 0.0 & 4.5 \\
\hline 83.0 & 3.0 & 0.9 & 0 & 30 & 70 & $<1$ & $<1$ & 0 & 100 & 0 & 2 & 2.0 & 0.0 & 4.0 \\
\hline 108.0 & 3.0 & 0.6 & 2 & 20 & 0 & 0 & 78 & 0 & 100 & 0 & 4 & 0.0 & 0.0 & 4.0 \\
\hline 111.0 & 3.0 & 2.1 & 20 & 5 & 0 & 0 & 75 & 0 & 99 & 1 & 3 & 0.0 & 0.0 & 2.0 \\
\hline 116.0 & 5.0 & 2.4 & 8 & 3 & 1 & 0 & 88 & $<1$ & 100 & 0 & 2 & 0.0 & 0.0 & 2.0 \\
\hline 124.0 & 5.0 & 3.2 & 5 & 3 & $<1$ & 0 & 92 & $<1$ & 100 & 0 & 3 & 0.0 & 0.0 & 2.0 \\
\hline 125.5 & 1.0 & 0.3 & 30 & 20 & 40 & 0 & 10 & 0 & 100 & $<1$ & 3 & 0.0 & 0.0 & 1.0 \\
\hline 150.5 & 5.0 & 2.4 & 0 & 8 & $<1$ & 0 & 92 & $<1$ & 100 & 0 & 3 & 3.0 & 0.0 & 2.5 \\
\hline 152.0 & 5.0 & 2.3 & 3 & 8 & 1 & 0 & 88 & $<1$ & 100 & 0 & 3 & 3.0 & 0.0 & 2.0 \\
\hline 162.5 & 4.5 & 1.6 & 0 & 15 & 1 & 0 & 84 & $<1$ & 100 & 0 & 3 & 3.5 & 0.0 & 3.5 \\
\hline 171.0 & 4.5 & 2.1 & 0 & 10 & 2 & 0 & 88 & $<1$ & 100 & 0 & 4 & 3.0 & 0.0 & 4.0 \\
\hline 175.0 & 3.5 & 0.7 & 0 & 10 & 0 & 0 & 90 & $<1$ & 100 & 0 & 4 & 3.0 & 0.0 & 0.0 \\
\hline
\end{tabular}

Other organic petrological observations are given in percent (volume), assuming $100 \%$ are visually characterized. TOC data (\% wt.), already presented in Table 1 , is shown again for comparison. 


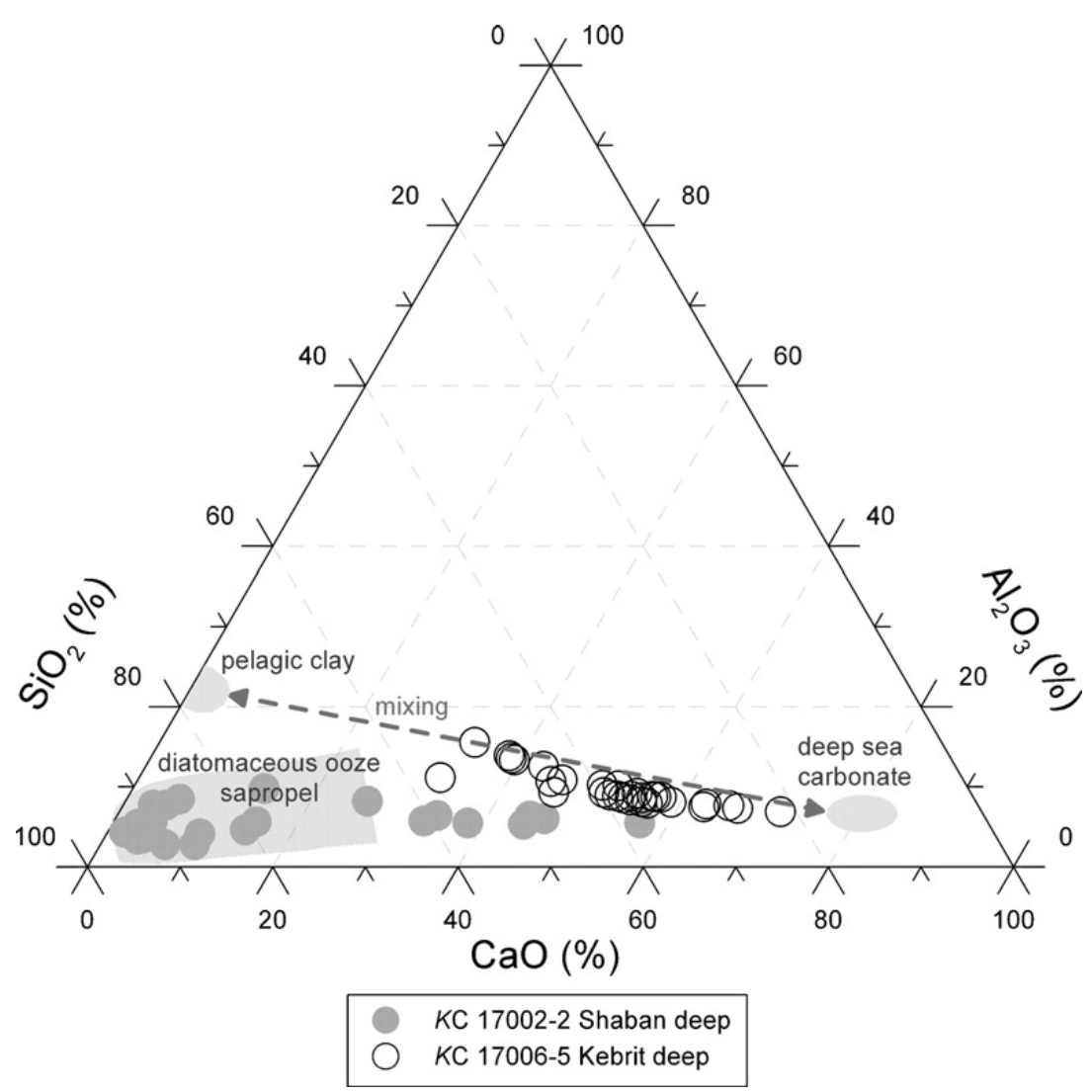

Fig. 4. Ternary diagram of major element compositions $\left(\mathrm{SiO}_{2}, \mathrm{Al}_{2} \mathrm{O}_{3}, \mathrm{CaO}\right)$ of sediment cores $K \mathrm{C} 17002-2$ (filled circles, Shaban deep) and $K \mathrm{C}$ 17006-5 (open circles, Kebrit deep). The Kebrit data plot near a mixing line (dashed line) between global deep-sea carbonate mud and global pelagic clay composition. Shaban data trace from carbonate mud to the shaded area, which represents the diatomaceous, organic-rich sediment in the Shaban deep (Table 1).

investigated in detail by Seeberg-Elverfeldt et al. (2004a,b). Diatoms were found to be the most abundant siliceous group in Red Sea sediments. According to Seeberg-Elverfeldt et al. (2004b; 2005) the diatomaceous sediments of core GeoB 5836-2 (taken in close vicinity to core 17002-2) represent the carbonatepoor "phase III" sediments. The authors, although having no absolute sediment age dating results available, estimated these diatomaceous sediments to be older than $34 \mathrm{ka}$.

\subsubsection{Sapropels}

Another major sediment type of the Kebrit- and Shaban deeps are organic-rich sediments (sapropels) with TOC values up to $8.4 \%$ (Table 1). Most prominent in core 17002-2 (Shaban deep) is the sapropel between 309 and $401.5 \mathrm{~cm}$ (Table 1; Fig. 2). Our ${ }^{14} \mathrm{C}$-dating results on sedimentary organic matter suggest a time of deposition between approximately 13.6 and $11.8 \mathrm{ka}$ (note that there is carbonate turbiditic sediment between 462 and $402 \mathrm{~cm}$ core depth) for the most prominent sapropel of core 17002-2, which coincides with the
Younger Dryas, a time when a fertile mixed water situation with high primary production prevailed (Legge et al., 2006). The inorganic composition of "phase II" sapropel from core GeoB 5836-2 is described in detail by Seeberg-Elverfeldt et al. (2004b, 2005). Without absolute sediment age dating results available, the authors estimated this sapropel as being deposited between 22 and $14 \mathrm{ka}$. However, both sapropels (e.g. the sapropel between 309 and $401.5 \mathrm{~cm}$ depth of core 17002-2 and the "phase II" sapropel from core GeoB 5836-2) can clearly be correlated by the stratigraphic position within the sediment sequence, sapropel thickness and laminae including internal lithified carbonate layers.

The absolute ${ }^{14} \mathrm{C}$-ages $(11.97 \mathrm{ka}$ at $325 \mathrm{~cm}$ and $12.75 \mathrm{ka}$ at $374 \mathrm{~cm}$ ) indicate a high average sedimentation rate near $70 \mathrm{~cm} / \mathrm{ka}$ for the diatom-rich sapropel in the Shaban deep (note that carbonate layers are sometimes present in the sapropel which are caused by turbidites or authigenic minerals - see core description in Fig. 2 and Stoffers et al., 1990; those turbidites and authigenic mineral layers are excluded in the calculation of the sedimentation rate). 
Although a matter of debate, Ba-contents of sediments have been used as a tracer of past productivity (Dymond et al., 1992; Kasten et al., 2001). The existence of anaerobic saline brines within the Kebritand Shaban deeps prevents large-scale postdepositional oxidation of organic matter, which could cause decoupling of Ba- and TOC-variations, as has been suggested by Kasten et al. (2001). Hence, the Ba concentrations of organic-rich sediments from Kebrit and Shaban deeps may be useful when studying sapropel formation. We observed a positive correlation of the organic carbon content with the Ba concentrations (Table 1; Fig. 5), which supports the idea of a high primary production being responsible for the formation of the Shaban deep sapropel deposited between 13.6 and $11.8 \mathrm{ka}$ (Table 1). Similarly, the parallel increase of Ba- and TOC contents at around $200 \mathrm{~cm}$ core depth (core 17002-2) suggests that this organic-rich layer is also the result of a (smaller) productivity pulse around $10.3 \mathrm{ka}$. The $\mathrm{Ba}_{\text {excess }}$ of $\mathrm{Fe}$ and $\mathrm{Zn}$-enriched hydrothermal affected sediments of the Kebrit deep (see below) is distinctly lower than the $\mathrm{Ba}_{\text {excess }}$ within the sapropels (Table 1). This also supports the idea that paleoproductivity pulses rather than hydrothermalism control the $\mathrm{Ba}_{\text {excess }}$ in the sediments of the Shaban and Kebrit deeps.

\subsubsection{Hydrothermally affected sediments}

Hydrothermal activity affecting Red Sea sediments has frequently been reported (Degens and Ross, 1969; Bignell et al., 1976 cited after Scholten et al., 2000; Coulibaly et al., 2006). Discharging hydrothermal solutions are trapped in isolated basins and deeps, which favour the preservation of hydrothermal deposits (summarised by Scholten et al., 2000). Organic-rich sediments deposited in Red Sea deeps may be affected by locally high heat flux causing organic matter maturation (Burke et al., 1981; Simoneit et al., 1987; Michaelis et al., 1990; Faber et al., 1998). In particular, Michaelis et al. (1990) concluded that hydrothermal petroleum generation caused petroleum impregnations of Kebrit and Shaban deep sediments. Moreover, petroleum-impregnated massive sulfides were found near the brine-sea water interface of the Kebrit deep (Hemleben et al., 1996a; Stoffers et al., 1998; Michaelis et al., 1990). Two types of massive sulfides occur which include a variety of ore minerals such as pyrite, marcasite, bravoite, sphalerite and galena (Missak, 1988; Blum and Puchelt, 1991 cited after Scholten et al., 2000). As a consequence, high concentrations of $\mathrm{Fe}, \mathrm{Zn}$ and $\mathrm{Pb}$ but relatively low $\mathrm{Cu}$ and $\mathrm{Ni}$ values (Missak, 1988 cited after Scholten et al., 2000) may occur in

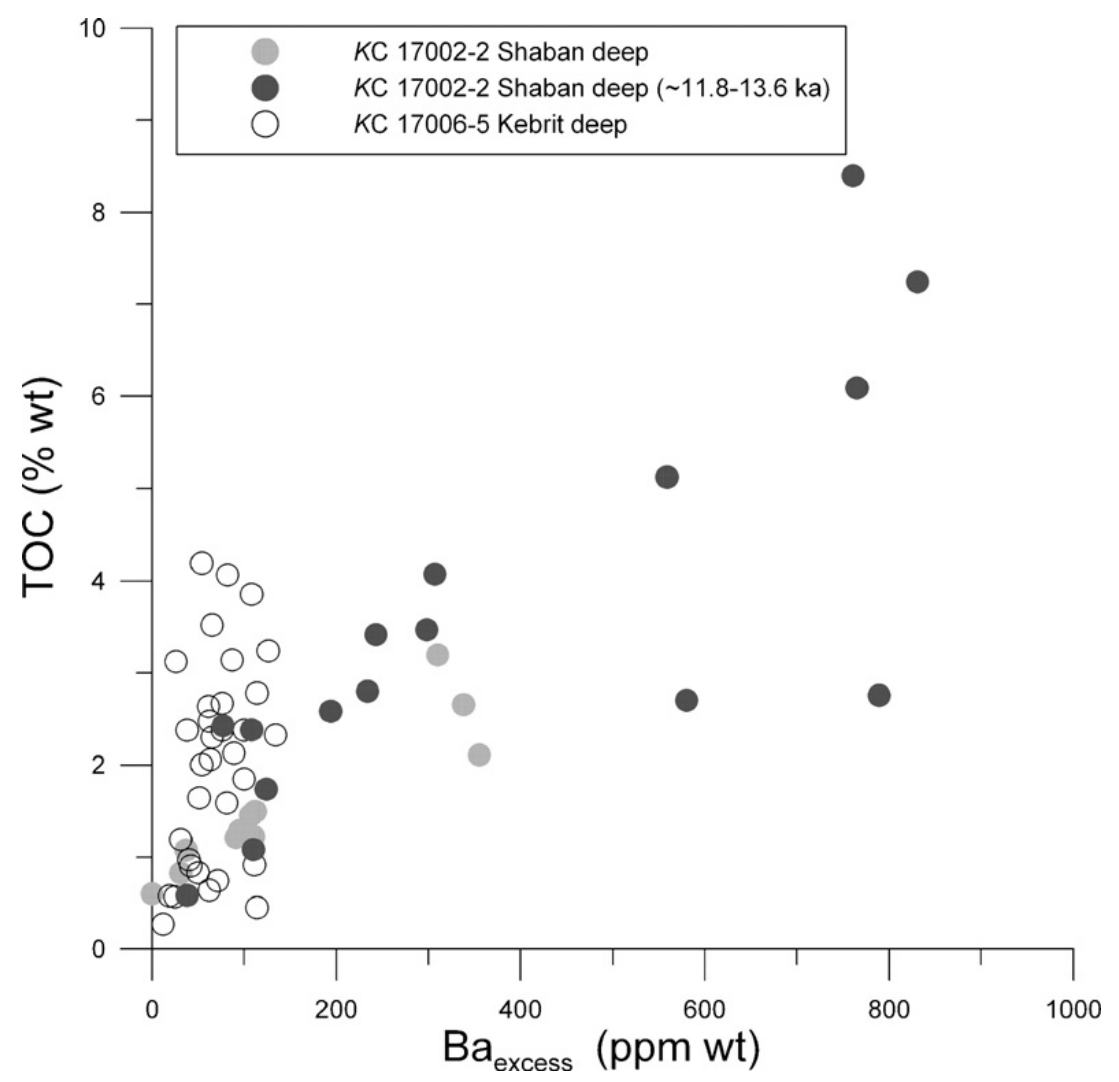

Fig. 5. Calculated $\mathrm{Ba}_{\text {excess }}$ versus total organic carbon content (TOC). 


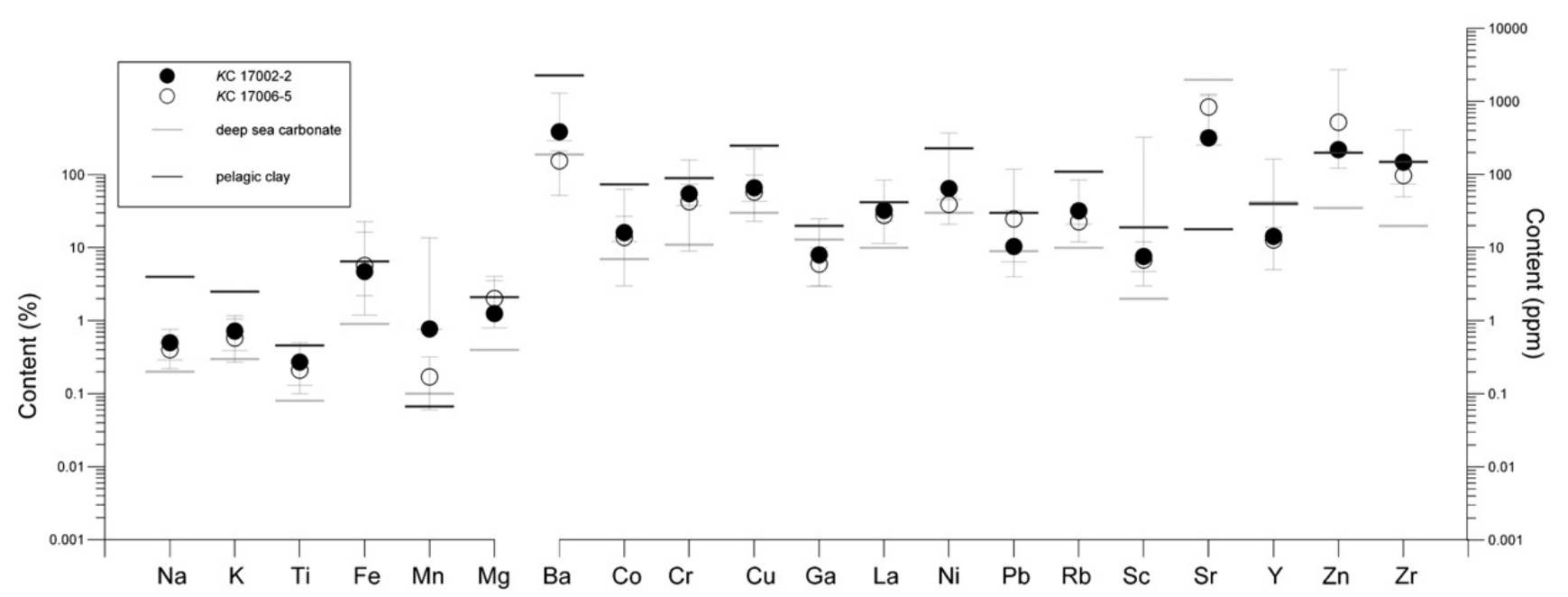

Fig. 6. Major and trace element compositions of cores 17002-2 (Shaban deep) and 17006-5 (Kebrit deep), compared to the global average element compositions of pelagic clay and marine carbonate mud (McLennan and Murray, 1999).

hydrothermal sediments from the Kebrit deep. Hence, hydrothermally affected sediments in the Kebrit deep should be recognized by Fe and $\mathrm{Zn}$ anomalies. Fig. 6 shows the concentrations (maximum-, minimum- and average values) of a selection of elements measured in the two sediment cores from Kebrit and Shaban deeps. As can be seen most elements plot in the range of concentrations typical for average pelagic clay, deep-sea carbonate, or mixtures of both. However, relatively high concentrations of $\mathrm{Fe}(22.8 \%$ and $16.2 \%$ at $111,125.5 \mathrm{~cm}$ core depth, resp.) and $\mathrm{Zn}$ (1944 to $2733 \mathrm{ppm}$ at 151.5, 152 and $198 \mathrm{~cm}$ core depth) measured for samples from the Kebrit core (Table 1), fall out of the range for normal marine sediments (Table 1; Fig. 6). Fe-enriched sediment layers (limonitic mud) in Kebrit sediments are recognised by their red to reddish-brown color (Bignell, 1975 cited after Scholten et al., 2000; core 17006-5, Fig. 3). These Fe-rich sediments are probably hydrothermal in origin. It is not clear, however, whether Kebrit deep sediments were influenced by Fe-rich hydrothermal solutions after deposition, or the sediments may contain redeposited $\mathrm{FeOOH}$-rich material, which originated from above the anaerobic brine. Based on organic-geochemical results (e.g. the pristane/ phytane ratios and the occurrence of the biomarker trisnorhopanone, see below) the existence of anaerobic saline brine within the Kebrit deep is indicated at least for the last approximately $3 \mathrm{ka}$. Sedimentation of FeOOH-rich material in contact with anaerobic $\mathrm{H}_{2} \mathrm{~S}$ rich brine is unlikely to occur. Thus, turbiditic transport and redeposition of $\mathrm{FeOOH}$-enriched sediment from the hydrothermal field above the brine seems more likely. Such Fe-rich materials in vicinity to massive sulfides have been observed near the brine-sea water interface of the Kebrit deep (e.g. Fig. 14.7 in Scholten et al., 2000). However, these FeOOH-rich sediments have not been observed in the Shaban deep. Here, Fe-enrichments to $16.3 \%$ within organic-rich sapropelic sediments are caused by pyrite. This is indicated by the linear correlation between Fe- and S-concentrations (Fig. 7). It is not clear, however, whether pyrite formation in Shaban deep sediments was already initiated (Seeberg-Elverfeldt et al., 2005) at the brine-sea water interface and continued to grow within the sediments. Alternatively, pyrite from the Shaban deep precipitated solely from sulfate-reduced, $\mathrm{H}_{2} \mathrm{~S}$-enriched, pore fluids.

Three layers with high $\mathrm{Zn}$ values occur tenths of centimeters apart from the limonitic horizon in the Kebrit deep sediments (Table 1, Fig. 6). Similar to the Fe anomalies it is unclear whether the $\mathrm{Zn}$ anomalies were caused by in situ hydrothermal precipitation or $\mathrm{Zn}$ perhaps originated at the brine-sea water interface as sphalerite (Blum and Puchelt, 1991 cited after Scholten et al., 2000), and subsequently was transported into the deep brine sediments.

\subsection{Organic petrology}

The results of microscopic observations of organic particles in Kebrit and Shaban deep sediments are listed in Table 2. Low TOC values $(<4 \%)$ correlate reasonably well with the amount of organic matter determined by microscopic observation (Table 2). High TOC values from sapropel sediments, however, are underestimated in regard to the microscopically observed organic matter contents. This may indicate significant contributions of extremely fine dispersed, perhaps amorphous, organic matter in the sapropel sediment. 


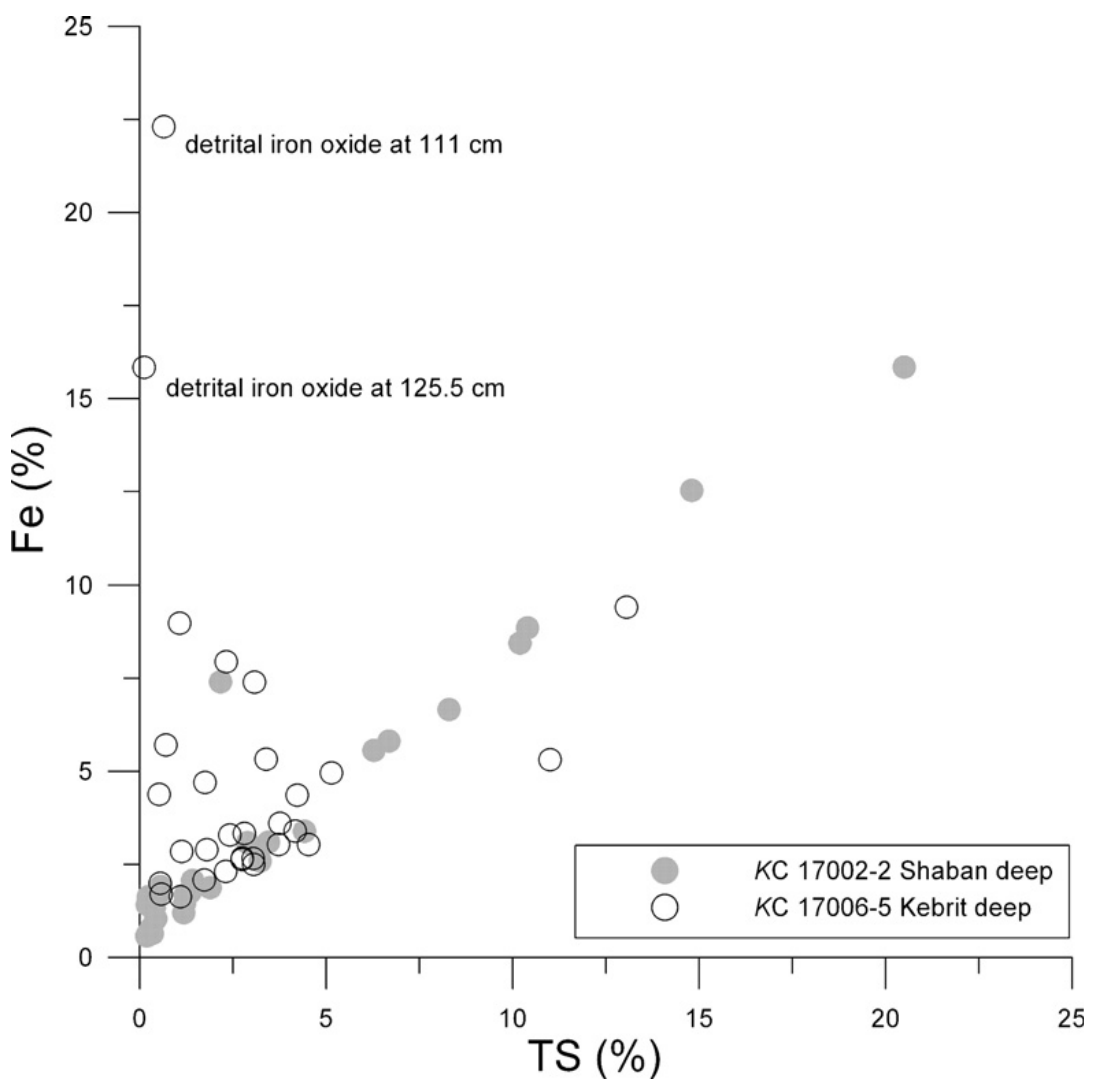

Fig. 7. Iron contents of sediments versus total sulphur (TS) indicate pyrite as major Fe-compound in the sediments. Two samples of $K \mathrm{C} 17006-5$ (Kebrit deep), with exceptional high Fe-content probably derived from detritic hydrothermal iron input.

Organic particle sizes are usually $<20 \mu \mathrm{m}$. Large particles $>100 \mu \mathrm{m}$ are rare. Major components are round and elliptical pellets and bituminite. Inertinite is rare within the sediments. It usually consists of small $<20 \mu \mathrm{m}$ semifusinite- and fusinite particles of terrestrial origin and is probably related to wind and/or turbiditic transport (Stach et al., 1982). Seldom are 5-10 $\mu \mathrm{m}$ thick higher reflecting stripes or sheets of faunal remains, which are attributable to chitinous eggs, and cuticles of arthropods. Liptinite is present in varying amounts in both cores. It occurs usually as small and very small $(<5 \mu \mathrm{m})$ sheets of algae (liptodetrinite), which are partly fragments of larger organisms or partly thin, unornamented sheets of globular algae of the nano- or even picoplankton. Rare are also planktonic algae up to $50 \mu \mathrm{m}$ like cysts of dinoflagellates and stripes or lenses of laminated algae. If laminated algae are present in sufficient amount forming microbial mats they may correspond with the gelatinous pellicles living at the brine-sea water interface (Erba et al., 1987; Erba,1991; Daffonchio et al., 2006). Polypantoporate and colpate pollen of angiospermae or dissaccate pollen of gymnosperms occasionally occur.

20 to $30 \mu \mathrm{m}$ large humic fragments sporadically occur in both cores. They are degraded and contain only occasionally reflecting material. Although only few measurements of the vitrinite reflectance (at $546 \mathrm{~nm}$ ) were possible the results suggest the maturity to be $<0.3 \%$.

The pellets are brown or grey in color. Their size is usually $6-10 \mu \mathrm{m}$, seldom smaller or up to $200 \mu \mathrm{m}$. They show usually no or weak brownish fluorescence. Their internal structure is extremely fine-grained (individual

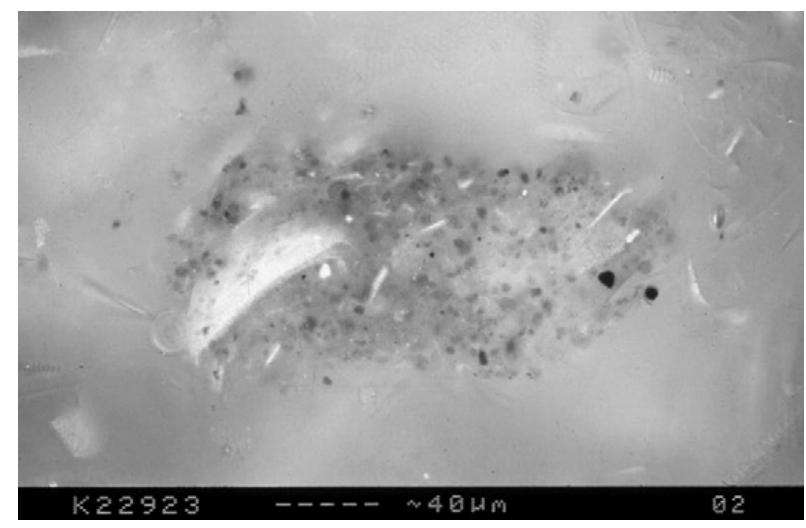

Fig. 8. Photography of organic-rich sediment of $K \mathrm{C} \quad 17002-2$ (microscopy in incident light). Color code: dark gray — fecal pellets; light gray — solitary algae and liptodetrinite; white fragments diatom shell. 
Table 3

Organic-geochemical data of cores 17002-2 (Shaban deep) and 17006-5 (Kebrit deep)

\begin{tabular}{|c|c|c|c|c|c|c|c|c|c|c|c|c|c|c|c|c|c|}
\hline $\begin{array}{l}\text { Sediment } \\
\text { depth } \\
(\mathrm{cm})\end{array}$ & $\begin{array}{l}\text { EOM } \\
\text { (ppm } \\
\mathrm{wt})\end{array}$ & $\begin{array}{l}\text { EOM/ } \\
\text { TOC } \\
(\mathrm{mg} / \mathrm{g})\end{array}$ & $\begin{array}{l}\text { S2(mgHC/ } \\
\text { gSediment) }\end{array}$ & $\begin{array}{l}\text { Carbon- } \\
\text { kerogene } \\
\text { (\% wt.) }\end{array}$ & $\begin{array}{l}\text { Pristane/ } \\
\text { phytane }\end{array}$ & $\begin{array}{l}\mathrm{HI} \\
\text { (mgHC/ } \\
\text { gTOC) }\end{array}$ & $\begin{array}{l}\text { CPI- } n \text { - } \\
\text { Alkane } \\
\text { (C15- } \\
\text { C25) }\end{array}$ & $\begin{array}{l}\text { CPI-FA } \\
\text { (C14- } \\
\text { C21) }\end{array}$ & $\begin{array}{l}\text { CPI-FA } \\
\text { (C22- } \\
\text { C30) }\end{array}$ & $\begin{array}{l}\sum n- \\
\text { Alkane } \\
(\mathrm{ppm} \\
\mathrm{wt})\end{array}$ & $\begin{array}{l}\sum \mathrm{FA} \\
(\mathrm{ppm} \\
\mathrm{wt})\end{array}$ & $\begin{array}{l}\sum n \text {-Alkane/ } \\
\text { TOC(ppm wt/ } \\
\% \text { wt.) }\end{array}$ & $\begin{array}{l}\delta^{13} \mathrm{C}- \\
\text { kerogene } \\
(\% \text { V- } \\
\text { PDB) }\end{array}$ & $\begin{array}{l}\text { UCM } \\
\text { A.U. }\end{array}$ & $\begin{array}{l}\text { Dinosterol } \\
\text { (ppm wt) }\end{array}$ & $\begin{array}{l}\text { Cholesterol } \\
\text { (ppm wt) }\end{array}$ & $\begin{array}{l}\text { TNH } \\
\text { (ppm } \\
\text { wt) }\end{array}$ \\
\hline \multicolumn{18}{|c|}{ Shaban deep kasten core 17002-2 } \\
\hline 12.5 & 462 & 43 & 109 & 27 & b.d.l. & 385 & b.d.l. & 0.05 & 0.06 & b.d.l. & 3.0 & b.d.l. & -22.1 & 0.2 & 0.4 & 0.3 & b.d.l. \\
\hline 104.0 & 218 & 36 & & & $\ll 1$ & & 0.90 & 0.03 & $\ll 1$ & 3.9 & 3.0 & 6.5 & & 0.6 & 0.3 & 0.2 & b.d.1. \\
\hline 180.0 & 526 & 64 & & & 1.1 & & 0.99 & 0.08 & 0.14 & 29.3 & 4.5 & 35.7 & & 14.1 & 0.4 & 0.4 & 0.1 \\
\hline 196.5 & 1810 & 68 & & & 0.8 & & 1.08 & 0.12 & 0.20 & 18.7 & 9.9 & 7.0 & & 1.8 & 2.1 & 0.9 & 0.5 \\
\hline 204.0 & 1812 & 57 & 73 & 22 & $\ll 1$ & 335 & 0.91 & 0.11 & 0.11 & 3.3 & 12.0 & 1.0 & -21.8 & 1.2 & 5.3 & 1.8 & 1.2 \\
\hline 305.0 & 1800 & 85 & 97 & 24 & $\ll 1$ & 353 & 0.93 & $\ll 1$ & $\ll 1$ & 11.2 & 10.2 & 5.3 & -22.1 & 2.2 & 1.8 & 1.3 & 6.6 \\
\hline 313.5 & 1960 & 72 & & & $\ll 1$ & & 1.07 & $\ll 1$ & $\ll 1$ & 7.0 & 6.0 & 2.6 & & 1.6 & 2.2 & 1.6 & 0.7 \\
\hline 316.5 & 1113 & 46 & & & $\ll 1$ & & 1.00 & 0.13 & 0.13 & 3.3 & 6.1 & 1.4 & & 0.9 & 1.3 & 0.9 & 0.7 \\
\hline 322.0 & 4290 & 105 & 30 & 9 & 1.3 & 305 & 1.02 & 0.09 & $\ll 1$ & 21.1 & 14.9 & 5.2 & -21.7 & 3.4 & 4.0 & 1.7 & 1.4 \\
\hline 325.5 & 8767 & 104 & 110 & 32 & $\ll 1$ & 385 & 0.73 & 0.07 & 0.10 & 18.4 & 36.6 & 2.2 & -22.1 & 5.5 & 11.8 & 5.4 & 7.5 \\
\hline 338.0 & 1397 & 59 & & & 1.2 & & 1.14 & 0.17 & 0.16 & 6.6 & 8.7 & 2.8 & & 2.5 & 3.1 & 1.5 & 2.8 \\
\hline 342.0 & 11412 & 414 & 115 & 33 & 1.5 & 386 & 1.50 & 0.18 & 0.09 & 22.5 & 64.5 & 8.2 & -23.1 & 24.2 & 13.8 & 8.0 & 7.6 \\
\hline 345.5 & 11163 & 185 & 57 & 18 & 1.0 & 312 & 0.91 & $\ll 1$ & $\ll 1$ & 43.9 & 12.4 & 7.3 & -22.2 & 9.3 & 11.0 & 7.9 & 4.2 \\
\hline 350.5 & 8977 & 124 & & & b.d.l. & & 1.16 & 0.11 & 0.08 & 26.2 & 33.0 & 3.6 & & 6.0 & 12.9 & 7.1 & 4.1 \\
\hline 357.5 & 13158 & 271 & 151 & 39 & 0.7 & 395 & 0.99 & 0.15 & 0.14 & 432.3 & 42.2 & 89.0 & -23.1 & 42.9 & 13.9 & 5.4 & 2.1 \\
\hline 360.5 & 6171 & 101 & & & b.d.l. & & 1.11 & 0.13 & 0.04 & 24.9 & 34.5 & 4.1 & & & 6.8 & 3.1 & 6.7 \\
\hline 370.0 & 2913 & 85 & 99 & 25 & 0.8 & 358 & 1.06 & 0.14 & 0.12 & 123.0 & 17.4 & 35.9 & -21.4 & 11.6 & 6.5 & 2.0 & 0.7 \\
\hline 377.0 & 6580 & 128 & & & 0.8 & & 1.16 & $\ll 1$ & 0.05 & 15.8 & 3.9 & 3.1 & & 1.6 & 6.1 & 2.6 & 1.5 \\
\hline 378.5 & 4922 & 142 & & & b.d.l. & & 1.43 & 0.04 & 0.03 & 3.7 & 12.3 & 1.1 & & & 4.3 & 1.5 & 1.0 \\
\hline 380.5 & 4329 & 167 & & & 1.7 & & 1.32 & 0.29 & 0.09 & 18.1 & 28.5 & 7.0 & & & 3.5 & 2.4 & 0.9 \\
\hline 383.0 & 3275 & 117 & & & 1.2 & & 1.12 & 0.06 & 0.07 & 26.0 & 51.8 & 9.3 & & & 2.4 & 1.1 & 3.0 \\
\hline 391.0 & 2937 & 169 & & & 0.8 & & 1.04 & 0.08 & 0.13 & 201.6 & 7.0 & 116.0 & & 15.2 & 0.3 & 1.2 & 2.4 \\
\hline 392.5 & 1150 & 106 & & & b.d.l. & & b.d.l. & 0.11 & $\ll 1$ & b.d.l. & 7.1 & b.d.l. & & 0.7 & 0.3 & 0.7 & 1.9 \\
\hline 395.5 & 315 & 54 & & & $\ll 1$ & & 1.03 & 0.16 & $\ll 1$ & 4.4 & 4.3 & 7.6 & & 0.5 & 0.7 & 0.5 & 0.6 \\
\hline 462.0 & 1075 & 88 & & & 1.1 & & 1.41 & 0.12 & $\ll 1$ & 18.1 & 8.8 & 14.8 & & 4.1 & 0.6 & 0.7 & 0.4 \\
\hline 480.5 & 1141 & 78 & & & 0.7 & & 1.04 & 0.09 & $\ll 1$ & 10.3 & 9.4 & 7.0 & & 3.1 & 0.4 & 0.6 & 0.6 \\
\hline 502.5 & 1300 & 107 & & & 1.1 & & 1.15 & 0.17 & $\ll 1$ & 100.6 & 9.1 & 82.8 & & 17.0 & 0.3 & 0.5 & 0.2 \\
\hline 554.0 & 1310 & 102 & & & 1.0 & & 0.98 & 0.11 & $\ll 1$ & 62.4 & 5.1 & 48.6 & & 14.2 & 0.5 & 0.4 & 0.2 \\
\hline 564.0 & 1424 & 95 & & & 1.1 & & 1.32 & 0.08 & $\ll 1$ & 13.0 & 4.2 & 8.7 & & 3.4 & 0.6 & 0.5 & 0.5 \\
\hline \multicolumn{18}{|c|}{ Kebrit deep kasten core 17006-5 } \\
\hline 5.0 & 1120 & 68 & & & 1.4 & & 1.2 & 0.08 & $\ll 1$ & 6.7 & 1.4 & 4.1 & & 0.9 & 2.6 & 16.5 & 2.5 \\
\hline
\end{tabular}


Table 3 (continued)

\begin{tabular}{|c|c|c|c|c|c|c|c|c|c|c|c|c|c|c|c|c|c|}
\hline $\begin{array}{l}\text { Sediment } \\
\text { depth } \\
(\mathrm{cm})\end{array}$ & $\begin{array}{l}\text { EOM } \\
\text { (ppm } \\
\text { wt) }\end{array}$ & $\begin{array}{l}\mathrm{EOM} / \\
\mathrm{TOC} \\
(\mathrm{mg} / \mathrm{g})\end{array}$ & $\begin{array}{l}\text { S2(mgHC/ } \\
\text { gSediment) }\end{array}$ & $\begin{array}{l}\text { Carbon- } \\
\text { kerogene } \\
\text { (\% wt.) }\end{array}$ & $\begin{array}{l}\text { Pristane/ } \\
\text { phytane }\end{array}$ & $\begin{array}{l}\mathrm{HI} \\
\text { (mgHC/ } \\
\text { gTOC) }\end{array}$ & $\begin{array}{l}\text { CPI- } n- \\
\text { Alkane } \\
(\mathrm{C} 15- \\
\text { C25) }\end{array}$ & $\begin{array}{l}\text { CPI-FA } \\
\text { (C14- } \\
\text { C21) }\end{array}$ & $\begin{array}{l}\text { CPI-FA } \\
\text { (C22- } \\
\text { C30) }\end{array}$ & $\begin{array}{l}\sum n- \\
\text { Alkane } \\
\text { (ppm } \\
\text { wt) }\end{array}$ & $\begin{array}{l}\sum \mathrm{FA} \\
(\mathrm{ppm} \\
\mathrm{wt})\end{array}$ & $\begin{array}{l}\sum n \text {-Alkane/ } \\
\text { TOC(ppm wt/ } \\
\% \text { wt.) }\end{array}$ & $\begin{array}{l}\delta^{13} \mathrm{C}- \\
\text { kerogene } \\
(\% 0 \mathrm{~V}- \\
\text { PDB) }\end{array}$ & $\begin{array}{l}\text { UCM } \\
\text { A.U. }\end{array}$ & $\begin{array}{l}\text { Dinosterol } \\
\text { (ppm wt) }\end{array}$ & $\begin{array}{l}\text { Cholesterol } \\
\text { (ppm wt) }\end{array}$ & $\begin{array}{l}\text { TNH } \\
\text { (ppm } \\
\text { wt) }\end{array}$ \\
\hline \multicolumn{18}{|c|}{ Shaban deep kasten core 17002-2 } \\
\hline 45.0 & 1530 & 66 & 29 & 12 & 1.8 & 209 & 1.9 & 0.06 & 0.14 & 7.0 & 2.3 & 3.0 & -20.9 & 0.5 & 4.3 & 19.4 & 13.0 \\
\hline 50.0 & 988 & 83 & & & 0.7 & & 1.2 & 0.06 & 0.08 & 15.7 & 2.4 & 13.2 & & 2.2 & 1.6 & 15.8 & 7.1 \\
\hline 51.5 & 2404 & 59 & 23 & 9 & 0.9 & 201 & 1.9 & 0.09 & 0.13 & 20.2 & 7.2 & 5.0 & -20.5 & 2.0 & 7.0 & 63.3 & 35.1 \\
\hline 53.0 & 2488 & 71 & & & 1.5 & & 1.6 & 0.14 & 0.14 & 9.9 & 20.3 & 2.8 & & 0.5 & 5.9 & 118.7 & 48.0 \\
\hline 56.0 & 352 & 61 & & & 0.7 & & 1.1 & 0.14 & 0.29 & 4.3 & 3.3 & 7.4 & & 0.3 & 0.2 & 5.2 & 6.2 \\
\hline 57.0 & 1227 & 61 & & & 1.2 & & 1.5 & 0.12 & 0.16 & 10.7 & 10.7 & 5.3 & & 0.4 & 1.4 & 22.9 & 26.4 \\
\hline 58.5 & 2550 & 66 & 34 & 16 & 2.1 & 219 & 2.7 & 0.17 & 0.13 & & & & -20.5 & 0.8 & & & \\
\hline 60.0 & 1747 & 71 & 45 & 18 & 1.7 & 229 & 1.8 & 0.08 & 0.13 & 4.5 & 9.2 & 1.8 & -20.7 & 0.5 & 3.1 & 53.3 & 27.8 \\
\hline 62.5 & 1345 & 32 & 48 & 23 & 1.2 & 238 & 1.1 & $\ll 1$ & $\ll 1$ & 8.6 & 2.0 & 2.0 & -21.3 & 0.7 & 1.4 & 1.0 & b.d.l. \\
\hline 64.5 & 370 & 40 & & & 0.5 & & 1.1 & $\ll 1$ & 0.17 & 4.6 & 2.7 & 5.0 & & 0.4 & b.d.l. & 0.1 & b.d.l. \\
\hline 68.0 & 1389 & 58 & 31 & 13 & 1.6 & 216 & 1.9 & 0.10 & 0.13 & 5.6 & 5.6 & 2.3 & -20.5 & 0.5 & 1.1 & 30.3 & 14.0 \\
\hline 69.5 & 445 & 54 & & & 0.5 & & 1.2 & 0.16 & 0.15 & 2.4 & 3.1 & 2.9 & & 0.1 & 0.4 & 1.7 & 1.2 \\
\hline 74.5 & 512 & 53 & 58 & 26 & 0.5 & 239 & 1.3 & 0.08 & 0.13 & 1.1 & 1.8 & 1.1 & -20.3 & 0.0 & 0.1 & 2.0 & 1.9 \\
\hline 78.0 & 1286 & 41 & & & 0.9 & & 1.2 & 0.06 & 0.15 & 5.4 & 6.7 & 1.7 & & 0.6 & 2.0 & 2.3 & 11.2 \\
\hline 108.0 & 1064 & 166 & & & 4.8 & & 1.4 & $\ll 1$ & $\ll 1$ & 2.4 & 1.4 & 3.8 & & 0.2 & 1.0 & 133.2 & 12.7 \\
\hline 111.0 & 1299 & 63 & & & 0.7 & & 1.0 & $\ll 1$ & $\ll 1$ & 19.0 & 1.4 & 9.2 & & 1.8 & 2.4 & 3.0 & 0.8 \\
\hline 116.0 & 1468 & 62 & & & 0.6 & & 1.1 & 0.07 & 0.18 & 1.7 & 6.3 & 0.7 & & 1.0 & 1.9 & 4.3 & 1.2 \\
\hline 124.0 & 2253 & 70 & & & 0.4 & & 1.1 & 0.07 & 0.16 & 8.1 & 6.6 & 2.5 & & 1.3 & 2.4 & 1.8 & 52.8 \\
\hline 125.5 & 96 & 35 & & & 0.6 & & 1.1 & 0.07 & 0.14 & 1.6 & 0.2 & 5.9 & & 0.1 & b.d.l. & 0.3 & 0.4 \\
\hline 150.5 & 1703 & 72 & & & 0.6 & & 1.1 & 0.09 & 0.14 & 16.5 & 5.3 & 6.9 & & 1.9 & 2.3 & 1.3 & 28.4 \\
\hline 151.5 & 1847 & 66 & & & 1.0 & & 1.1 & 0.10 & 0.14 & 18.0 & 11.6 & 6.5 & & 1.4 & 3.5 & 1.5 & 41.2 \\
\hline 152.0 & 1944 & 84 & & & 1.6 & & 1.1 & $\ll 1$ & 0.13 & 13.7 & 3.8 & 5.9 & & 1.7 & 3.1 & 1.8 & 33.9 \\
\hline 153.5 & 222 & 39 & & & 1.0 & & 1.1 & 0.07 & 0.26 & 3.1 & 2.8 & 5.5 & & 0.1 & 0.2 & 0.3 & 3.4 \\
\hline 162.5 & 1111 & 70 & & & 0.7 & & 1.1 & 0.14 & 0.12 & 7.2 & 1.8 & 4.5 & & 0.9 & 0.7 & 1.4 & 13.1 \\
\hline 171.0 & 1767 & 83 & & & 0.8 & & 1.1 & $\ll 1$ & $\ll 1$ & 34.2 & 1.4 & 16.0 & & 4.1 & 2.6 & 3.3 & 24.4 \\
\hline 175.0 & 445 & 60 & & & 0.7 & & 1.0 & $\ll 1$ & b.d.l. & 8.1 & b.d.l. & 10.8 & & 1.0 & 0.7 & 0.7 & 5.9 \\
\hline
\end{tabular}

EOM: Extractable Organic Matter.

TOC: Total Organic Matter.

S2-Peak: Rock Eval analysis (Espitalié et al., 1977).

HI: Hydrogen Index (Rock Eval hydrocarbon generation potential)

CPI: Carbon Preference Index (carbon odd/even ratio. modified after Bray and Evans (1961). cited in Tissot and Welte (1984): e.g. $\frac{\text { CPI }=\sum_{1}^{i=5} C_{15+2 i}}{2 \sum^{i=5} C_{16+2 i}}$ )

FA: Fatty Acids.

UCM: Unresolved Complex Mixture.

TNH: 22,29,30-trisnorhopan-21-one

A.U.: arbitrary unit.

b.d.l.: below detection limit.

blank cell: not measured. 
grains $<1 \mu \mathrm{m})$. The round shape of the pellets may gradually convert into lens-shaped forms or "Schlieren" which often can not be distinguished from bituminite. The pellets consist of intimately mixtures of organic matter with inorganic material (Fig. 8). They are definitely biogenic in origin and they are most likely produced as excrements from unknown organisms. To distinguish them from the fecal pellets (SeebergElverfeldt et al., 2005), which are considerable larger $(>100 \mu \mathrm{m})$, they are here defined as micropellets.

Bituminite is the second major component, which can be observed in the sediments. It occurs as small lenses or stripes of irregular shape. Bituminite is brown in color, shows weak to middle brownish-yellowish fluorescence and is extremely fine-grained like the micropellets. Although a few exceptions occur (Kebrit deep: 83, 74.5, 69.5, and $64.5 \mathrm{~cm}$ ), bituminite contents of Kebrit deep sediments are usually $<20 \%$. As there is a positive correlation between TOC measurements and microscopic estimations of $\mathrm{OM}$ contents, we may assume that pellets represent the major part of the organic matter in Kebrit sediments. The situation is more difficult in case of the Shaban deep, however, where relatively high bituminite contents are observed. Microscopic observations indicate that pellets often degrade and change into bituminite like structures (see above). Thus, it is possible that the original pellet content of the sediments was higher than the actual pellet/bituminite ratios indicate.

\subsection{Organic geochemistry of sediments}

\subsubsection{Kerogens}

The TOC contents of the sediments within Kebrit and Shaban deeps range from 0.1 to $8.4 \%$ (Table 1). The highest TOC values were found for sapropel sediments in the Shaban deep between 309 and $401.5 \mathrm{~cm}$ core depth. All sediments with elevated TOC $(>1 \%)$ values are finely-laminated and olive gray or olive green to olive black in color. Relatively low TOC values, however, are measured for light-colored carbonate-rich sediments often intercalated with laminated intervals (Fig. 2). Seeberg-Elverfeldt et al. (2004b, 2005) studied the inorganic constituents of organic-rich laminated sediments in the Shaban deep and found that the laminations represent two-season annual varves. Diatoms were regarded as fall/winter deposition and coccoliths are thought to reflect a summer signal. Consequently, one major source of the high organic carbon contents in Shaban deep sapropelic sediments is related to bioproductivity in Red Sea surface water. Another organic carbon source, however, is related to the brine-sea water interface. There, density gradients delay sedimentation of organic particles and gradients of chemicals, including permutations of electron donors and acceptors may enhance microbial diversity, activity and biogeochemical cycling (D'Hondt et al., 2004; Parkes et al., 2005; Daffonchio et al., 2006).

Rock Eval pyrolysis of kerogens from both deeps show $T_{\max }$ values near $450{ }^{\circ} \mathrm{C}$. Most Kebrit deep samples have a shoulder at $360{ }^{\circ} \mathrm{C}$, however, which probably indicates the presence of thermal labile components containing more functional groups. The idea of a stronger conversion of Kebrit kerogens is supported by the lower hydrogen index (HI) values between 200-240 mgHC/gTOC, whereas the HI values of the Shaban kerogens are higher between 305 and $395 \mathrm{mgHC} / \mathrm{gTOC}$. The mean HI determined after Langford and Blanc-Valleron (1990) are $222 \mathrm{mgHC} /$ gTOC for Kebrit and $357 \mathrm{mgHC} / \mathrm{gTOC}$ for Shaban kerogens (Table 3). These $\mathrm{HI}$ are in the same range of values (e.g. 200-400 mgHC/gTOC) found for anoxic laminated sediments from the oxygen minimum zone (TOC up to 4\%) deposited at the continental slope of the north Arabian Sea (Littke et al., 1997). Hence, it is concluded that a significant hydrocarbon formation did not occur in the sediments of the Shaban and Kebrit deeps. Michaelis et al. (1990), however, from the epimerization of extended hopanes, concluded that hydrothermal petroleum formation occurred in sediments of the Kebrit and Shaban deeps. This is possible as thermal influences causing maturation of sedimentary organic matter may be locally restricted. More information about regional aspects of hydrocarbon production within the Kebrit and Shaban deep sediments would be required in order to draw final conclusions about the extent of hydrothermal hydrocarbon formation.

The stable carbon isotope values of Shaban deep kerogen samples are relatively low between -21.4 and $-23.1 \%$ whereas the Kebrit kerogen samples have slightly less negative $\delta^{13} \mathrm{C}$ values between -20.3 and $-21.3 \%$. Apparently, the amount of organic carbon present in the samples does not influence the stable carbon isotope values of the kerogens (Table 3). The range of isotope values between -20.3 and $-23.1 \%$ for Shaban and Kebrit deep kerogens fall into the known range of marine organic matter and, more specifically, the values are typical for warm water plankton (Saxby, 1972; Weber and Sackett, 1981; Sackett, 1989).

The organic matter of both deeps is of type II quality (Fig. 9), and neither organic-petrographical observations nor $n$-alkane spectra support the idea that significant inputs of terrestrial organic carbon are responsible for the relatively low stable carbon isotope values measured 


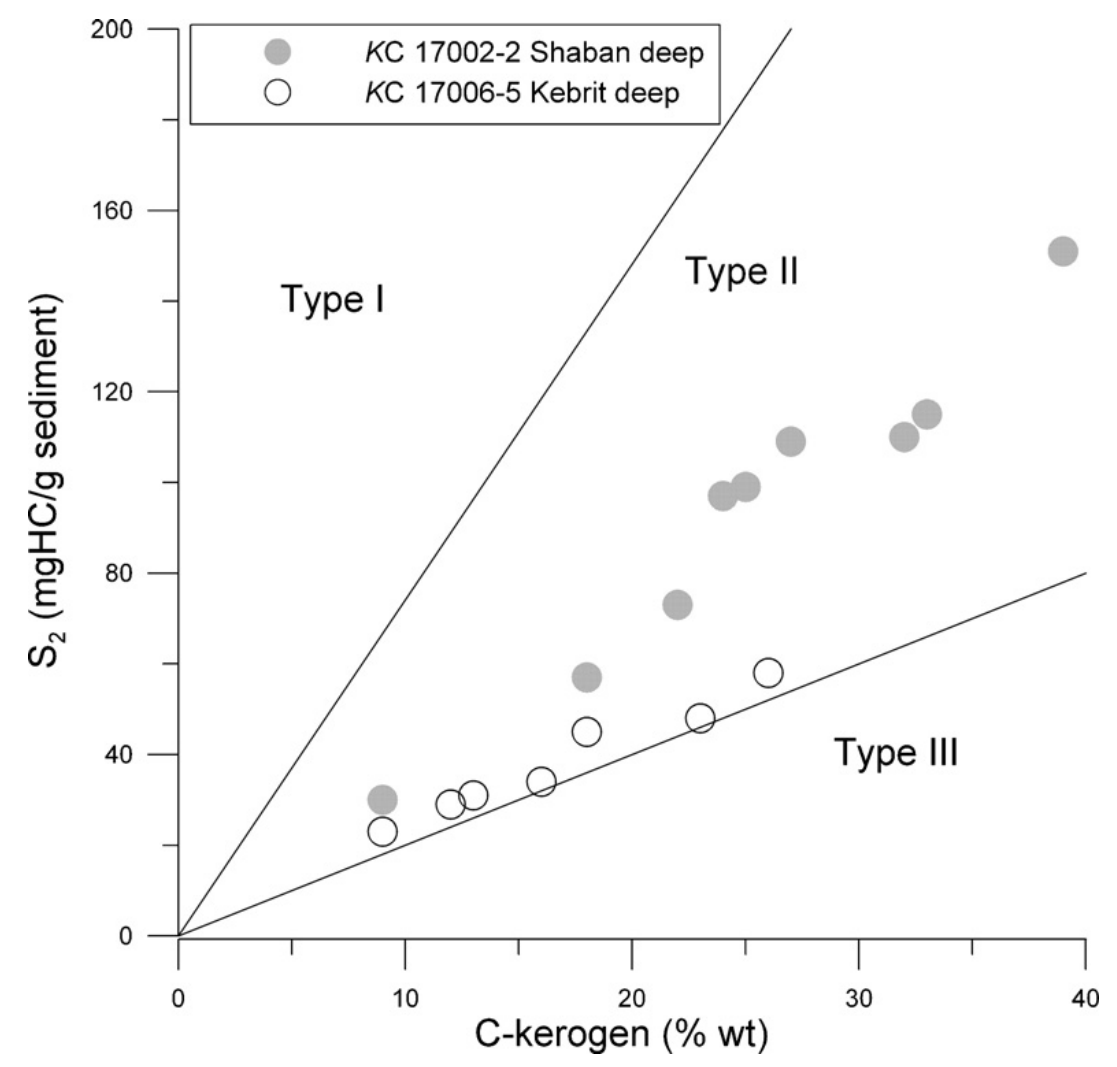

Fig. 9. Rock Eval hydrocarbon generation potential (S2) relative to the carbon content of kerogen (Langford and Blanc-Valleron, 1990). Although differences are noticeable type II kerogens are indicated for the sediments sampled from Shaban and Kebrit deeps.

for Shaban deep kerogens (Table 3; Fig. 10). Hence, variable ${ }^{13} \mathrm{C} /{ }^{12} \mathrm{C}$ ratios in Red Sea surface water during organic matter production and/or diagenetic changes might explain the isotopic variations of the kerogens.
The ${ }^{14} \mathrm{C}$ measurements of organic matter from both deeps indicate absolute sediment ages between approximately 2 and $21 \mathrm{ka}$ (note, however, that sediments deposited between approximately 3 and 10 ka were not

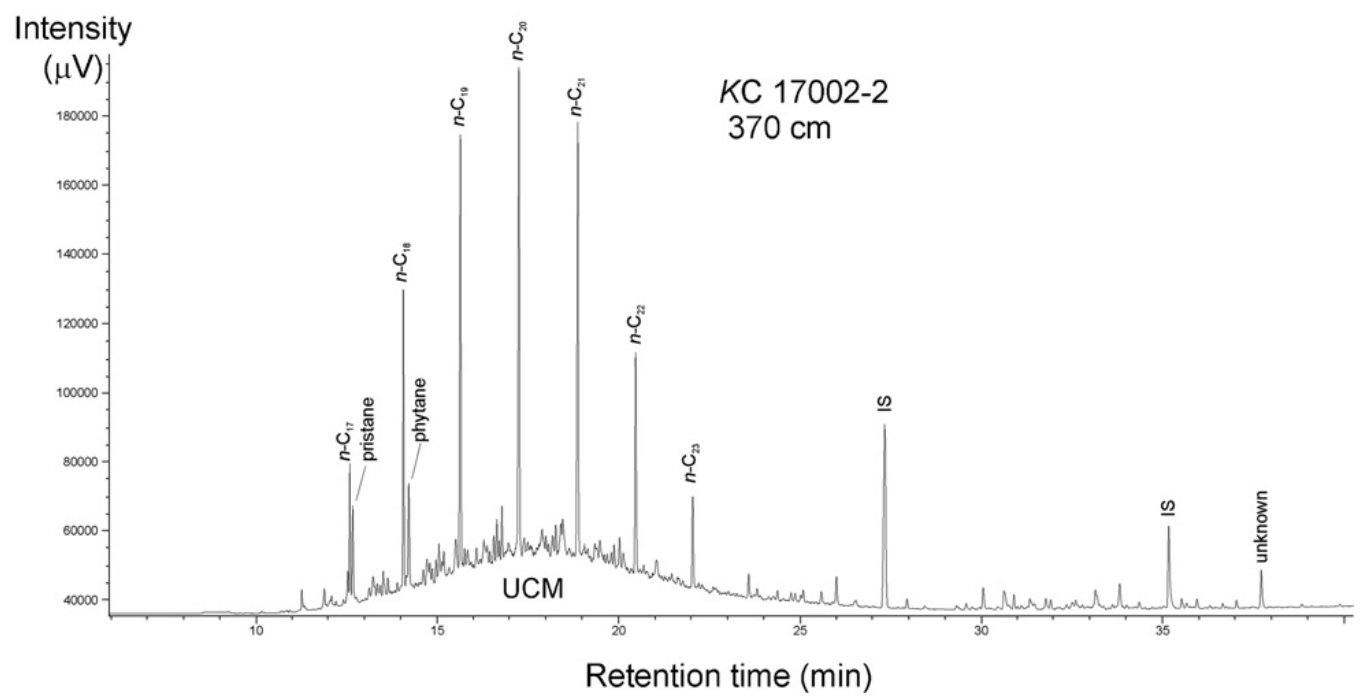

Fig. 10. Typical gas chromatogram of the $n$-alkane fraction. The subsample $(K C 17002-2,370 \mathrm{~cm})$ is representative of the sapropel recovered from Shaban deep (Table 1). Identified compounds are indicated. The distribution curve of hydrocarbons center around $n$ - $\mathrm{C}_{20}$. Unresolved complex mixture (UCM) is present in most of the samples. Long chain hydrocarbons are present in very small amounts and coelute with other unidentified compounds (IS = internal standard). 
cored; Table 1). Thus, theoretically, changes of stable carbon isotope values of sedimentary organic matter by diagenetic processes could have occurred as a consequence of the preferential loss of isotopically enriched (e.g. amino acids) or depleted (e.g. lipids) components (Macko et al., 1994). Hence, stable isotope compositions of bulk sedimentary organic matter sampled during variable diagenetic stages are difficult to interpret.

Low amounts of TOC of 0.1 and $0.2 \%$ were recovered by in situ filtering of water from brine-sea water interfaces (Table 4). The $\delta^{13} \mathrm{C}$ values of sedimenting bulk organic matter are lighter by $\sim 1-4 \%$ o than those of subrecent bulk organic matter from surface sediments $(0-1 \mathrm{~cm}$ of the multicorers; Table 4). Compounds usually depleted in ${ }^{13} \mathrm{C}$ relative to biomass (e.g. lipids) are included in the bulk sedimenting organic material but are not considered in kerogens. The stable carbon isotope values of all (except one) young bulk organic matter samples, however, have less negative values compared with the relatively old kerogens from the Shaban sapropel. For instance, kerogen from surface sediment of the Shaban deep is enriched in ${ }^{13} \mathrm{C}$ by $\sim 2$ to $3 \%$ relative to the $10.5-12.6 \mathrm{ka}$ old kerogens deeper in the core (e.g. sampling interval $204-370 \mathrm{~cm} ; \delta^{13} \mathrm{C}$ between -21.4 and $-23.1 \%$; Table 3).

The Kebrit and Shaban deeps contain highly saline brines, which tend to reduce biodiversity (Benlloch et al., 2002). Moreover, metabolic activities are significantly higher in the chemocline than in the overlying seawater and underlying brine (Daffonchio et al., 2006). During early diagenesis the organic matter within highly saline brine sediments is only subjected to anaerobic microbial degradation processes. Hence, we may assume that the most effective early degradation of sedimenting organic matter in the deeps probably occurs near the redoxcline, which today is located at the brine- sea water boundary. In that respect it is noteworthy that both the pr/ph-ratios and the presence of the biomarker TNH suggest that the Shaban brine probably existed for at least $15 \mathrm{ka}$ (see below).

Kerogens from the Shaban deep sapropel, although significantly older $(11.8-13.6 \mathrm{ka})$ than the kerogens from the Kebrit deep (2-3 ka), have a higher hydrocarbon generation potential (Table 3; Fig. 9) and also delivered larger amounts of extractable organic matter (see below). This indicates that the relatively young organic matter from the Kebrit deep experienced a higher degradation (which most likely occurred at the brine-sea water interface) than the older kerogens from the Shaban deep sapropel. A likely explanation for these differences is that the oxidation of organic matter was reduced during glacial to postglacial times when the Shaban deep sapropel was deposited. During that time the redoxcline was probably at a lower water depth above the brine-sea water boundary (Coulibaly et al., 2006). Hence, sedimenting organic matter rapidly settled through the water column and redoxcline and then, slow anaerobic degradation may have taken place at the brine-sea water boundary.

Even though degradation of organic matter in the sapropelic sediment of the Shaban deep is relatively low its stable carbon isotope values deviate significantly from the values measured for recent bulk organic matter (filter samples) and bulk organic matter from sediment surfaces (multicorer samples from both deeps; Table 4). As organic matter degradation is probably not responsible for the observed differences in the isotopic compositions of kerogens from the Kebrit and Shaban deeps it is more likely that the different isotopic values are determined by variations of Red Sea surface water, thus reflecting changes in the nutrient level (e.g. ${ }^{12} \mathrm{C}$ content) of sea water. The nutrient contents of Red Sea

Table 4

Organic-geochemical data of brine - in situ filter samples and surface sediment samples (MUC)

\begin{tabular}{|c|c|c|c|c|c|c|c|c|}
\hline Sample ID & Deep & $\begin{array}{l}\text { TOC } \\
\text { ( } \% \text { wt.) }\end{array}$ & $\begin{array}{l}\delta^{13} C_{\mathrm{TOC}} \\
(\% \text { V-PDB) }\end{array}$ & $\begin{array}{l}\text { Cholesterol } \\
\text { (ppm wt) }\end{array}$ & $\begin{array}{l}\text { Dinosterol } \\
\text { (ppm wt) }\end{array}$ & $\begin{array}{l}\text { TNH } \\
\text { (ppm wt) }\end{array}$ & $\begin{array}{l}\delta^{13} \mathrm{C}-\mathrm{TNH} \\
(\% \text { V-PDB) }\end{array}$ & $\begin{array}{l}T^{\mathrm{a}} \\
\left({ }^{\circ} \mathrm{C}\right) \\
\end{array}$ \\
\hline MUC-GeoB-7802-1 & Shaban-S & 3.1 & -19.5 & 11.6 & 3.6 & 8.9 & -19.0 & 24.0 \\
\hline MUC-GeoB-7831-2 & Shaban-N & 3.5 & -19.1 & 28.9 & 5.9 & 33.3 & -21.6 & 22.9 \\
\hline MUC-GeoB-7812-2 & Kebrit & 2.9 & -20.4 & 37.6 & 3.4 & 17.5 & -20.2 & 23.4 \\
\hline IF-127-3 & Shaban-S & 0.1 & -21.2 & 4.43 & b.d.l. & b.d.l. & b.d.l. & 22.7 \\
\hline IF-127-4 & Shaban-S & 0.1 & -19.9 & 6.01 & b.d.l. & b.d.l. & b.d.l. & 23.9 \\
\hline IF-132-1 & Shaban-N & 0.1 & -22.5 & 1.65 & b.d.l. & b.d.l. & b.d.l. & 22.5 \\
\hline IF-132-2 & Shaban-N & 0.1 & -20.1 & 1.49 & b.d.l. & b.d.1. & b.d.1. & 22.9 \\
\hline IF-144-1 & Kebrit & 0.2 & -24.4 & 7.64 & b.d.l. & b.d.l. & b.d.l. & 22.1 \\
\hline
\end{tabular}

TOC: Total Organic Matter.

TNH: 22,29,30-trisnorhopan-21-one.

b.d.1.: below detection limit.

${ }^{\text {a }}$ Brine temperature (Schmidt et al., 2006). 
water was probably much higher during deglaciation and in particular during the Younger Dryas (13.1-11.7 ka; Legge et al., 2006) when the Shaban sapropel formed than it was 2 to $3 \mathrm{ka}$ ago, at times when the organic matter of core 17006-5 was deposited in the Kebrit deep.

\subsubsection{Lipid biomarkers}

The amount of extractable organic matter (EOM) of Kebrit and Shaban deep sediments correlates with the total

(a)

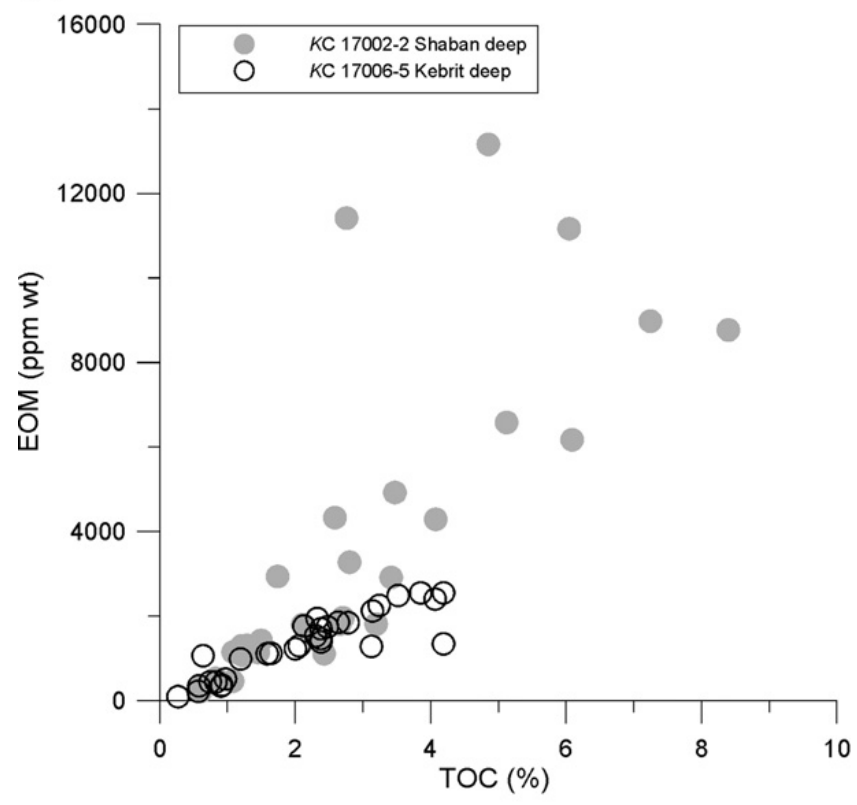

(c)

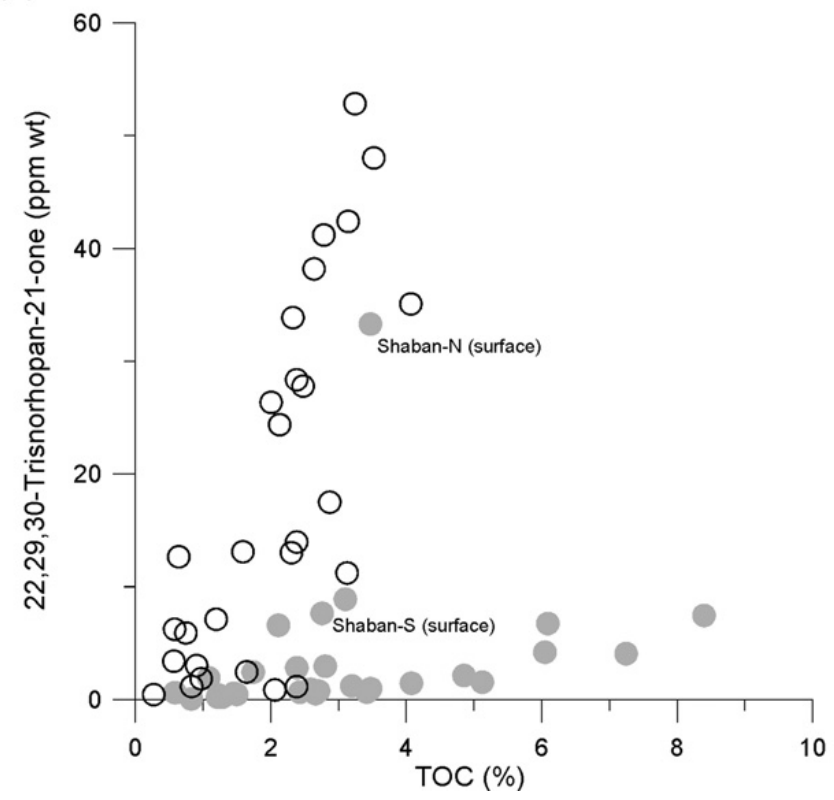

organic carbon contents (Fig. 11a). The EOM/TOC ratios are higher for the Shaban sediments $(36-414 \mathrm{mgEOM} /$ gTOC) than for the Kebrit sediments (32-166 mgEOM/ gTOC). The EOM/TOC values from both deeps are similar to the values reported by Michaelis et al. (1990) for Kebrit- (85-166 mgEOM/gTOC) and Shaban- (40$247 \mathrm{mgEOM} / \mathrm{gTOC}$ ) sediments. Largely marine organic carbon source(s) can be assumed for both deeps in the northern Red Sea. Hence, the differences in the amounts

(b)

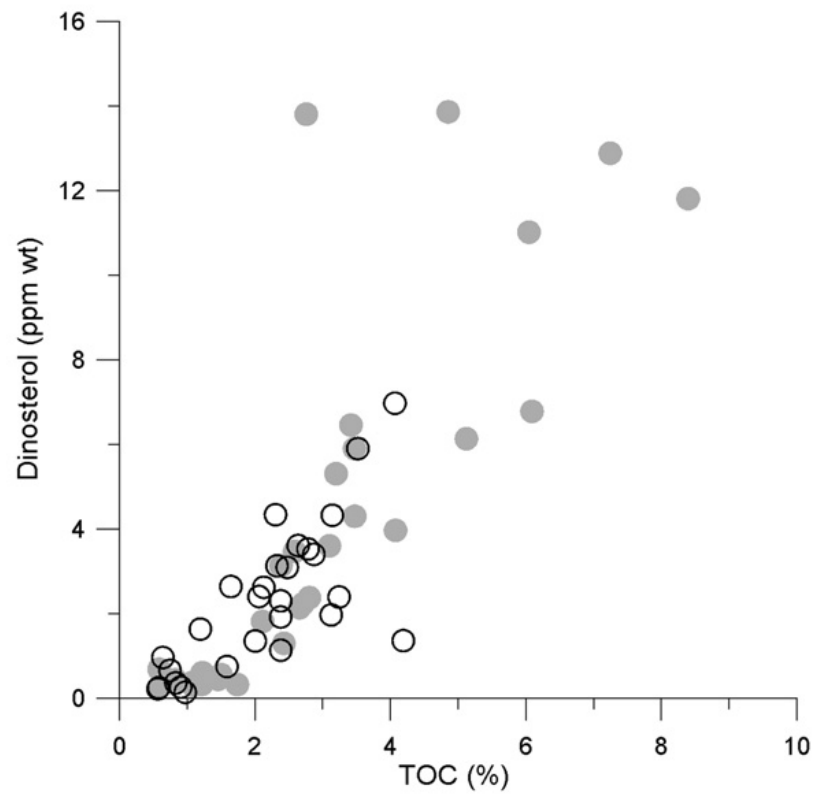

(d)

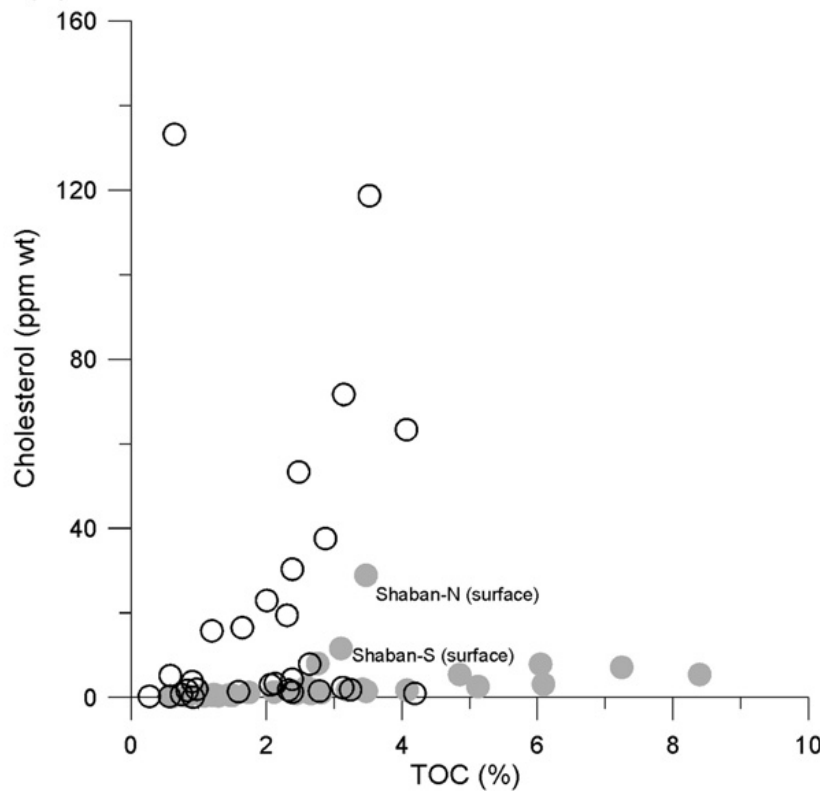

Fig. 11. (a) Extractable organic matter (EOM) versus TOC; (b) The biomarker dinosterol versus TOC content. The correlation indicates that dinoflagellates control much of the organic matter input to the sediments; (c) 22,29,30-trisnorhopan-21-one (TNH) versus TOC content. 11,80013,600 years old sapropel sediments from Shaban deep have high organic contents and low TNH values; (d) Biomarker cholesterol versus TOC. 
of extractable organic matter also indicates that, although older, the organic matter from the Shaban deep is less microbially degraded than that from the Kebrit deep. We found no increase of extractable organic matter with increasing core depth, however, neither for the Kebrit- nor the Shaban sediments. The three samples from the Shaban deep with the highest EOM/TOC ratios (at 342, 345.3, $357.5 \mathrm{~cm}$ ) derived from laminated black organic-rich diatomaceous oozes (Table 3; Fig. 2). Those sediments showed no indications of a hydrothermal influx (see above).

3.3.2.1. n-alkanes. $N$-alkanes are minor constituents of the soluble organic matter of the Kebrit and Shaban deep sediments (Table 3; Fig. 10). The $n$-alkane distribution of the sediments is usually dominated by $n-\mathrm{C}_{15}$ to $n-\mathrm{C}_{25}$ chain lengths with a maximum of $n-\mathrm{C}_{20}$ and/or $n-\mathrm{C}_{21}$. The Carbon Preference Index (CPI, see Bray and Evans, 1961) in the range $n-\mathrm{C}_{15}$ to $n-\mathrm{C}_{25}$ is between 0.7 and 1.5 (Table 3). Only some Shaban deep samples (e.g. 305, 325, 377-391, $480 \mathrm{~cm}$ core depth) have bimodal distributions with long-chain $n$-alkanes $>n-\mathrm{C}_{25}$ up to $n-\mathrm{C}_{35}$. In that $n$-alkane range higher CPI values between 1.2 and 3.0 (not presented here), show the preference of odd carbon number chains.

In some of the near-surface sediments of the Kebrit deep $(5 \mathrm{~cm}$ to $79 \mathrm{~cm}) n-\mathrm{C}_{17}$ is the most dominating $n$-alkane. Here the CPI values between 1 and 2.7 in the $n-\mathrm{C}_{15}$ to $n-\mathrm{C}_{25}$ range are strongly influenced by $n$ - $\mathrm{C}_{17}$. This $n$-alkane is formed by many phytoplankton species (Meyers and Ishiwatari, 1993; Silliman et al., 1996; Muri et al., 2004; Sachse et al., 2004). Similar to the few Shaban deep sediments, 3 Kebrit samples (e.g. at $57,151.5,153.5 \mathrm{~cm}$ core depths) have bimodal distributions since they also have $n$-alkanes in the longchain range. These long-chained $n$-alkanes show a strong odd-even predominance. This may indicate an origin from terrestrial plant waxes (Eglinton \& Hamilton, 1963; Kolattukudy \& Walton, 1972; Simoneit, 1978a), but organic matter from diatoms may also supply long-chained $n$-alkanes (Lichtfouse et al., 1994; Zegouagh et al., 1998).

In contrast, hydrocarbons lower than $n-\mathrm{C}_{23}$ are attributed to an autochthonous origin, where $n-\mathrm{C}_{17}$ and $n-\mathrm{C}_{19}$ are representative of a primary residue from bacteria and algae (Han et al., 1968; Orò et al., 1967; Youngblood et al., 1971; Grimalt and Albaiges, 1987; Simoneit et al., 1987). The ratios $n$-alkanes to per cent of organic carbon (Table 3), indicate that there is no systematic change of the ratios with depth suggesting that thermal production of hydrocarbons within the sediment column is not relevant.
The pristane/phytane (pr/ph) ratios are generally low ( $\ll 1$ to $\sim 1$; Table 3 ). This indicates anoxic conditions (Didyk et al., 1978) or, alternatively, an input of organic matter from archaebacteria into hypersaline environments may be responsible (Kaplan and Baedecker, 1972; TenHaven et al., 1985, 1987). Phylogenetic studies, revealing the occurrence of halophilic bacteria and archaea living in the Kebrit and Shaban brine-sea water interface, brine and sediment-brine interface (Eder et al., 2001, 2002), may assist the latter process. However, there is no indication of e.g. biogenic $\mathrm{CH}_{4}-$ production in brine of Kebrit and Shaban deep (Faber et al., 1998; Schmidt et al., 2003). In some cases the pr/ ph ratio is $>1$, which theoretically could indicate a change of environmental conditions. However, highsaline anoxic brine bodies situated within submarine depressions are only subjected to long-time diffusive processes (Anschutz and Blanc, 1996; Schmidt et al., 2003) and thus, variable sediment composition due to redeposition from outside the brine rather than rapid changes of environmental conditions likely is responsible (note for instance $\mathrm{pr} / \mathrm{ph}$ of 4.8 for the sample at $108 \mathrm{~cm}$ core depth from the Kebrit deep).

3.3.2.2. Fatty acids. The absolute amounts of fatty acids are lower in the Kebrit deep than in the Shaban deep sediments (Table 3). The n-carboxylic acid of both sediment cores have bimodal distributions in the range from $n-\mathrm{C}_{16}$ to $n-\mathrm{C}_{32}$. In most cases fatty acids maximize at $n-\mathrm{C}_{16}$ and $n-\mathrm{C}_{18}$ and in the range $n-\mathrm{C}_{24}$ to $n-\mathrm{C}_{28}$. A distinct preference of even-numbered fatty acids was noted and thus, low CPI values between 0.03 and 0.29 for the Shaban and 0.05 and 0.29 for the Kebrit sediments are calculated for ranges $n-\mathrm{C}_{14-21}$ and $\mathrm{n}-\mathrm{C}_{22-30}$ (Table 3). In Kebrit and Shaban deep sediments where the amount of terrigenous organic matter is very low the dominant $\mathrm{n}-\mathrm{C}_{16}$ and $\mathrm{n}-\mathrm{C}_{18}$ fatty acids are ascribed to a marine plankton source.

3.3.2.3. Unresolved complex mixture (UCM). Unresolved branched and cyclic hydrocarbons are present in numerous samples from the Kebrit deep and also in most samples from the Shaban deep (Table 3; Fig. 10). In all cases UCM ranges between $n-\mathrm{C}_{16}$ and $n-\mathrm{C}_{25}$ and maximizes at $n-\mathrm{C}_{20}$ and $n-\mathrm{C}_{21}$. These unresolved hydrocarbons may be due to microbial activity (Simoneit, 1978b; Johnson and Calder, 1973) or to catagenetic decomposition of organic matter (Tissot and Welte, 1984). It is noteworthy that the young Kebrit sediments have uniformly low UCM contents, whereas the UCM contents of the much older (but less degraded) Shaban deep sediments are more variable with high and low 
values in close vicinity (Table 3 ). The highest UCM contents were found within sapropel sediments and diatomaceous oozes deposited below $309 \mathrm{~cm}$ core depth in the Shaban deep. However, neither the Shaban nor the Kebrit deep sediments show a systematic trend of increasing UCM values with the increase in sediment depths, which formerly was ascribed to hydrothermal hydrocarbon generation in the Kebrit deep (Michaelis et al., 1990).

Hence, microbial activity within the sediments rather than thermal degradation of organic matter probably caused the UCM contents in sediments from the Kebrit and Shaban deeps. There is some evidence that microbial processes do occur within brine sediments. Core $378 \mathrm{KL}$ also taken from the southern subbasin of the Shaban deep (Stoffers et al., 1990) revealed authigenic carbonate layers within sapropelic sediments. Stable carbon- and oxygen isotope investigations indicated that sulfate reduction processes were responsible for their formation (Stoffers et al., 1990). Sediment core 17002-2 positioned in close vicinity to core $378 \mathrm{KL}$ also contains authigenic (semi-)lithified carbonate layers (Fig. 2). This suggests that sulfate reduction processes and authigenic carbonate precipitation also occurred in the sediments of core 17002-2. Furthermore, Table 1 and Fig. 7 indicate that in TOC-rich (>2\%) sediments $\mathrm{Fe}$ is predominantly consumed by the formation of pyrite, whereas in sediments with $<2 \%$ TOC a large excess of Fe over S may be observed. If the probably redeposited hydrothermal (limonitic) Fe in the Kebrit sediment core is not considered, the excess of Fe over $\mathrm{S}$ in (anoxic) brine sediments suggests that the organic matter content may be a limiting factor in the microbial sulfate reduction process, which apparently is not inhibited due to the existing highly saline pore water conditions.

\subsubsection{Steroides, ketones and aliphatic alcohols.}

Within the lipid fraction alkenones and sterols are dominating compounds. The total long-chain alkenone concentration $\left(\mathrm{C}_{37}-\mathrm{C}_{39}\right.$ alkenones $)$ in Shaban and Kebrit deep sediment samples is most likely related to the productivity of coccolithophore species E. huxleyi in surface water (Volkman et al., 1980) and other haptophyte algae (Rontani et al., 2004, 2006). Moreover, estimates on sea surface temperature were deduced from the so-called UK 37 index (Brassel et al., 1986; Müller et al., 1998). For glacial and postglacial sediments in the northern Red Sea the relative abundances of $E$. huxleyi were determined and a detailed UK 37 temperature curve was established (Legge et al., 2006). Thus, we decided not to elaborate further on the alkenone concentrations and UK 37 surface water temperatures as derived from Kebrit and Shaban deep sediments. We focus on the abundance of individual sterol compounds in organic-rich sediments of the Kebrit and Shaban deeps, which we found to be most indicative for major changes in the paleoceanographic conditions of the northern Red Sea (see below).

The identified sterols in Kebrit and Shaban deep sediments are cholest-5-en-3 $\beta$-ol (cholesterol), $5 \alpha$-cholestan-3 $\beta$-ol (cholestanol), 4,23,24-trimethyl-5-cholest22E-en-3-ol (dinosterol), 24-methyl-cholest-5-en-3 $\beta$-ol

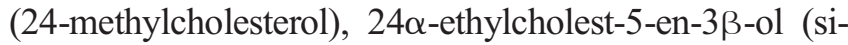
tosterol), $24 \alpha$-ethylcholest-5,22-dien-3 $\beta$-ol (stigmasterol).

Furthermore, relatively large amounts of 1,15triacontan-diol, 15-keto-triacontan-1-ol and 22,29,30trisnorhopan-21-one (TNH) are also present. The abundant biomarker molecules dinosterol, cholesterol and TNH in the sediments of the Kebrit- and Shaban deep are preferentially discussed, variable concentrations are shown in Table 3, and are identified in the selected chromatograms (Fig. 12a-c). Abundances of these biomarker molecules are determined by important groups of organisms, which reflect the (paleo-)oceanographic situations in the northern Red Sea since the LGM and enlight the formation of organic-rich sediments within the brine-filled deeps.

The major free sterol in all samples from the Shaban deep (KC 17002-2) and in a great part of samples from the Kebrit deep (KC 17006-5) is dinosterol, which correlates positively with both the TOC values and the total amounts of extract (Table 3; Fig. 11b). The biological source of dinosterol are dinoflagellates (Boon et al., 1979). Thus, dinoflagellates probably control much of the organic carbon supply to the Kebrit and Shaban deep sediments. Subrecent surface sediments, which were collected by multicorer sampling also contain dinosterol (Table 4). This biomarker was absent, however, in extract samples derived from in situ filtering (IF-samples in Table 4), of brine-sea water interfaces performed in March 2002 (M52-3 cruise). Besides detection limits $(\mathrm{TOC}=0.1-0.2 \%$ ) the reason for low dinoflagellate contents in the water could be that the abundance of dinoflagellates fluctuates seasonally. They commonly multiply rapidly in late spring or summer, after the maximum diatom concentration and when nutrients are most abundant (Williams et al., 1978).

The finely-laminated, organic-rich, diatomaceous sediments below $309 \mathrm{~cm}$ of core 17002-2 from the Shaban deep reflect a high-productivity stage during deglaciation in the northern Red Sea (Legge et al., 2006) and formation of (perhaps annual) varves occurred 
(a)

(a)

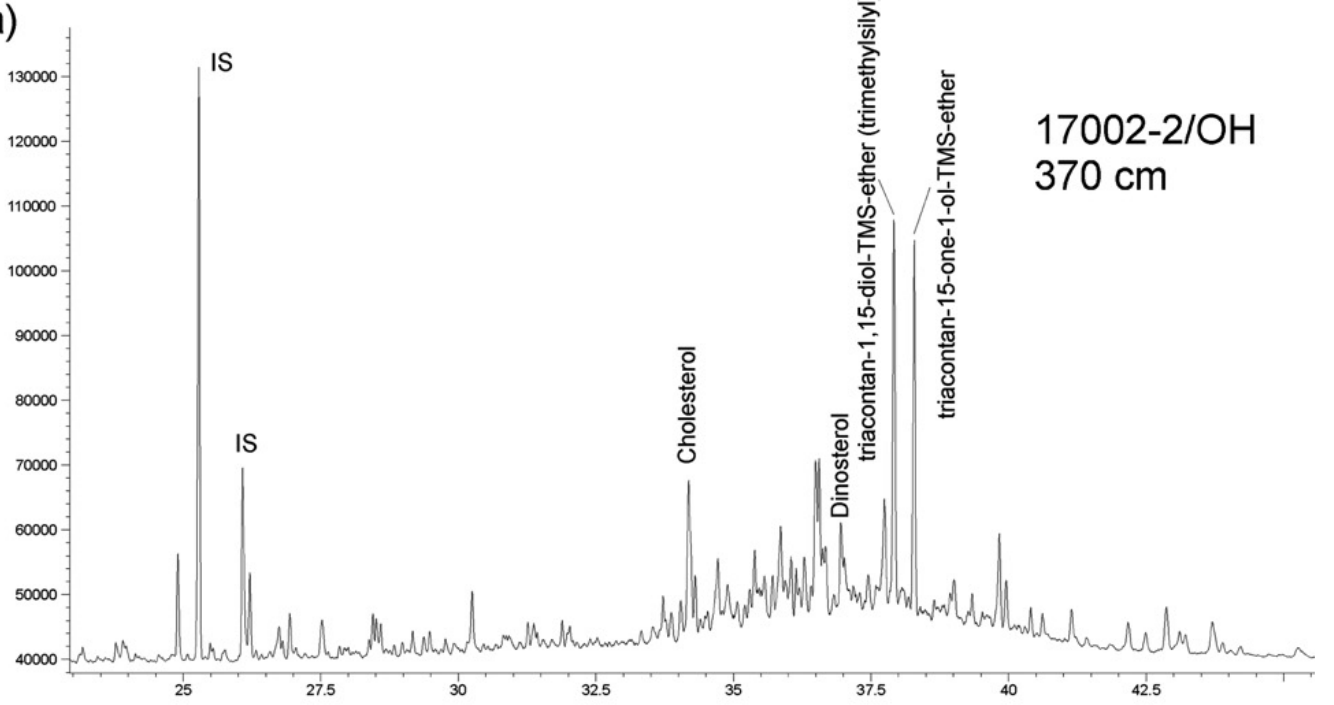

(b)

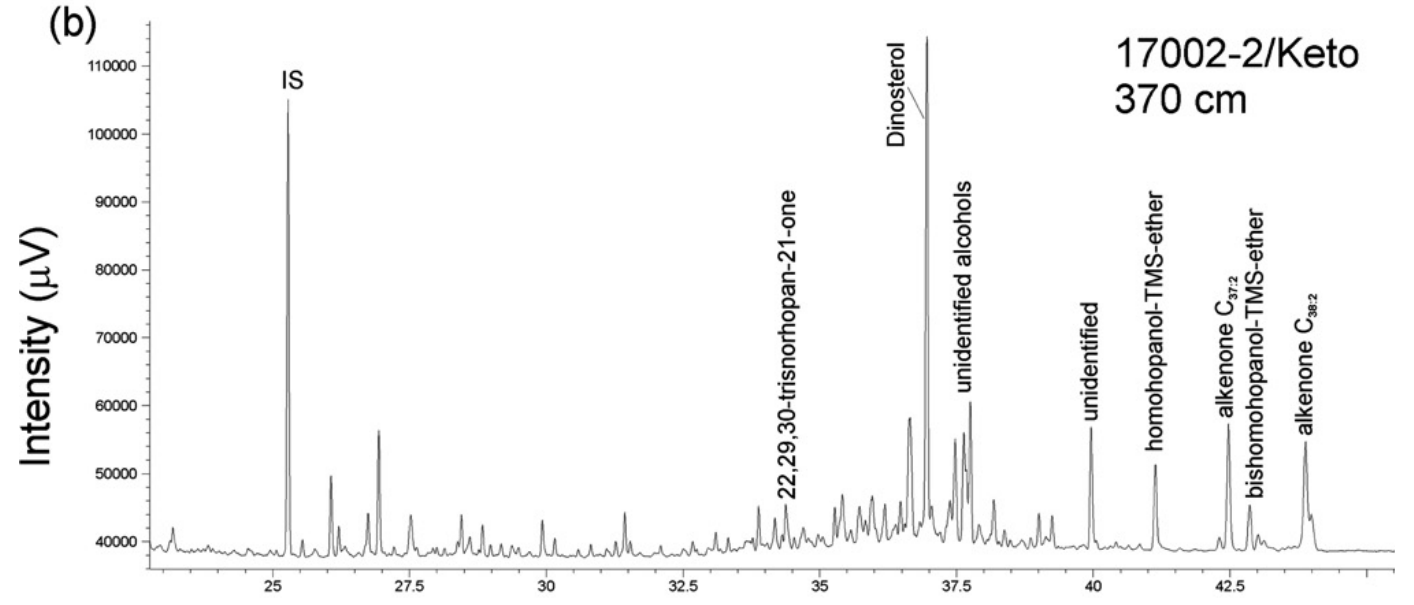

(c)

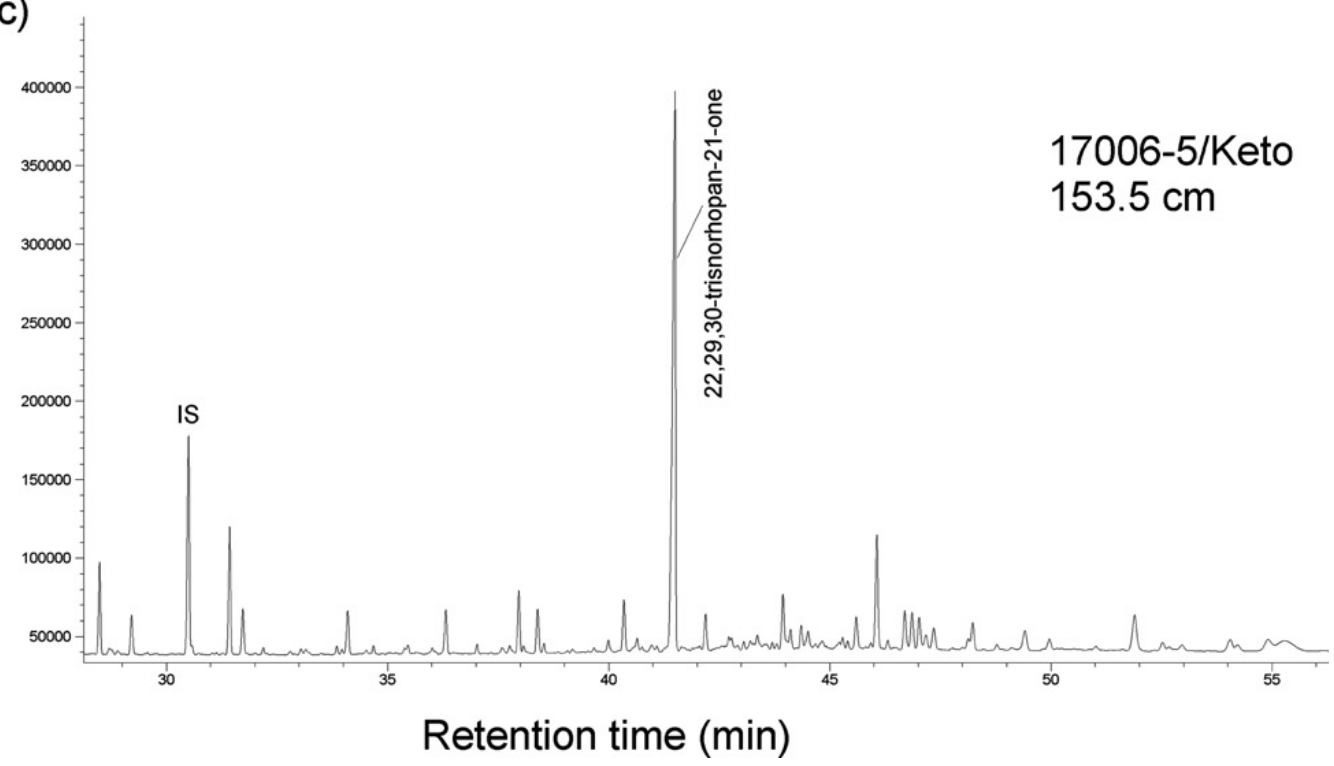

Fig. 12. Selected typical gas chromatograms of fractions of different polarity. Cholesterol, dinosterol, 22,29,30-trisnorhopan-21-one, internal standards (IS), and further specified compounds are marked. 
(Seeberg-Elverfeldt et al., 2004a). Hence, the high dinosterol contents of these organic-rich (sapropelic) sediments from the Shaban deep mirror high bioproductivity in the northern Red Sea during deglacial time.

Positive correlations of TNH vs. TOC (Fig. 11c) and cholesterol vs. TOC (Table 3; Fig. 11d) were only observed for the sediments from the Kebrit deep. Cholesterol is considered to be mainly produced by eukaryotes (Wakeham et al., 1997). Subrecent surface sediments (from multicorers) contain cholesterol in similar amounts to the sediments derived from the kasten core (Table 4). The highest amounts of cholesterol were found in laminated dark greenish to gray (organic-rich) sediments from the Kebrit deep between 5 and $68 \mathrm{~cm}$ core depth (the probably redeposited sediments near $108 \mathrm{~cm}$ are not considered here). Moreover, cholesterol was also detected in samples taken by in situ filters from the brine-sea water interface of both deeps (Table 4). Near-surface sediments from the Kebrit deep contain relatively large amounts of foraminifera, which contribute to the high carbonate content (Table 1; Hemleben et al., 1996a). Accordingly, core descriptions of core 17006-5 (Hemleben et al., 1996a and Fig. 3) showed that the upper part of the Kebrit core contains numerous foraminifera-rich sediment layers. In contrast, the generally carbonatepoor sediments (except the turbidite between approximately 400 and $460 \mathrm{~cm}$ ) of the lower half of the Shaban core (Fig. 2) contain much less cholesterol although these sediments have by far the highest TOC and EOM contents. Diatomaceous oozes from the Shaban core were deposited between $21.1 \mathrm{ka}$ and $11.8 \mathrm{ka}$ at times of relatively high bioproductivity and subsequent sapropel formation during Younger Dryas time in the northern Red Sea (see above). Although at that time the primary production was relatively high (planktonic) zooplankton production in Red Sea surface water was perhaps still low (Berggren and Boersma, 1969; Fenton et al., 2000) or, alternatively, sedimenting carbonate shells have been dissolved in the acidic brine.

TNH in sediments probably results from microbial degradation of intact bacteriohopanepolyol (BHP), which are indicators for bacterial abundances and phyla, and, hence, TNH was used as an indicator for bacterial activity (Santos et al., 1994; Conte et al., 2003). TNH was found to significantly contribute to the organic matter content of the sediment cores from the Kebrit- and Shaban deeps (Table 3, Fig. 12c). Up to $33.3 \mathrm{ppm}$ TNH was also found in the extremely soft surface sediments of the deeps, which were collected by multicorers (Table 4). Kiriakoulakis et al. (2001) cited Cho and Azam (1988) and stated that "the presence of this bacterial marker may signify either bacterial reworking of particulate material during transport through the water column, or repackaging of bacteria in fecal pellets by mid-water zooplankton". Gagosian et al. (1982) reported the occurrence of TNH in water column particulate organic matter collected in sediment traps. The increasing concentration of this compound with depth, observed in the oxic water column of the equatorial Atlantic, was interpreted as evidence for an increase in microbial transformation/oxidation processes with depth. We investigated a reference sediment core from outside the brine body of the Kebrit deep and found no TNH in these normal Red Sea sediments. Similarly, TenHaven et al. (1987) found cholesterol and $\mathrm{TNH}$ as major compounds present only in sediments from the anoxic brine-filled Tyro basin in the eastern Mediterranean and ascribed TNH production to an input of microbiota living at the brine-sea water interface. As was mentioned before, a strong density gradient at the brine-sea water boundary prevents rapid sinking of organic particles and here bacterial degradation and thus, possible TNH production, reaches a maximum. We tried to confirm the idea of TNH production at the brine-sea water boundary also by analysing in situ filter samples from that zone. Only very little organic matter was present in filter samples $(\mathrm{TOC}=0.1-0.2 \%)$ and $\mathrm{TNH}$ was not detected in organic extracts of the filter material derived from brine-sea water interfaces (Table 4).

Further information on the origin of $\mathrm{TNH}$ in sediments of the brine-filled deeps could come from the stable carbon isotope composition of TNH from surface sediments. The $\delta^{13} \mathrm{C}$ value of a TNH sample from the Shaban North deep is $-21.6 \%$ and from the Shaban South deep the value is $-19.0 \%$ o (subsamples were taken within two days). TNH from the Kebrit deep has a $\delta^{13} \mathrm{C}$ value of $-20.2 \%$. The stable carbon isotope value of TNH is dependent on the carbon isotope fractionation between sea water $\mathrm{CO}_{2}$ and the organic matter produced from it, and the fractionation occurring during the degradation of the TNH precursors. As there is no obvious relationship between the carbon isotope value of subrecent TNH from surface sediments and the modern brine $\mathrm{CO}_{2}\left(\delta^{13} \mathrm{C}\right.$ between -2 and $-12 \%$; Schmidt et al., 2006), the actual process of TNH formation within the brine-sea water interface remains unknown.

The question arises why most Kebrit deep sediments have much higher TNH contents than the Shaban deep sediments (Table 3; Fig. 11c). It has been stated above that sedimentary organic matter within relatively young Kebrit deep sediments reflects the modern relatively low 
bioproductive situation in the northern Red Sea. In contrast, sapropel sediments of the Shaban core were deposited during deglacial times and relatively high bioproductivity, and all surface sediments of the three Red Sea deeps (e.g. Shaban South-, Shaban North- and Kebrit deeps) have significantly higher TNH contents than the organic-rich (sapropel) sediments from the Shaban South deep (Tables 3 and 4). Theoretically, it could be that the TNH content of relatively old sediments from the Shaban core 17002-2 was reduced during diagenesis. However, TNH concentrations were highest in case of the stronger degraded organic matter from the Kebrit deep. According to the occurrence of $\mathrm{TNH}$ in very degraded organic material in the water column (Conte et al., 2003) this also suggests that TNH is produced during bacterial degradation/oxidation of organic matter. Then the formation of $\mathrm{TNH}$ was apparently relatively low during times of high bioproductivity and sapropel formation. However, it should be kept in mind that the formation of TNH from its precursors is not fully understood. Hence, the quantification of bacterial activity using the TNH concentration bears some uncertainties. The sapropel sediments (Fig. 2) were formed between 13.6 and $11.8 \mathrm{ka}$ (Table 1) during deglaciation (marine isotope stage 2). It has been mentioned before that during this time the redox front (redox boundary) was probably not at the brine-sea water interface but higher in the water column between 1000 and $2000 \mathrm{~m}$ water depth (Coulibaly et al., 2006). Consequently, under low-oxygenated bottom water conditions in the northern Red Sea organic particles accumulating at the brine-sea water interface were only subjected to anaerobic degradation processes, which would explain the relatively low TNH contents in sapropelic sediments from the Shaban deep. The situation is different in the modern deeps where the redox boundary is directly related to the brine-sea water interface. Today the accumulating organic matter is subjected to strong aerobic and, subsequently anaerobic bacterial degradation processes at the brine-sea water interface where probably also TNH is produced.

\section{Conclusions}

Based on ${ }^{14} \mathrm{C}$ dating of sedimentary organic matter the cores from the Shaban and Kebrit deeps in the Red Sea revealed up to $21.1 \mathrm{ka}$ old sediments. Major sediment types recovered were 1) carbonaceous sediments which are often turbiditic in origin; 2) laminated diatomaceous oozes reflecting times of low carbonate production in surface waters at the end of the last glacial maximum (LGM, marine isotope stage 2) through deglaciation; 3) sapropelic sediments with organic carbon contents up to $8.4 \%$ deposited during postglacial time between 11.8 and $13.6 \mathrm{ka}$ (Younger Dryas).

The $\delta^{13} \mathrm{C}$ values of the kerogens from the most prominent sapropel in the Shaban deep indicate an enrichment of ${ }^{12} \mathrm{C}$-rich nutrients in the water column during postglacial sapropel formation in the Younger Dryas.

Accordingly, positive correlations of Ba concentrations with the TOC-values suggest that high bioproduction in the northern Red Sea and high sedimentation rates (up to approximately $70 \mathrm{~cm} / \mathrm{ka}$ ) caused the sapropel formation in the deeps.

Organic petrological observations showed that the sedimentary organic matter largely consists of fecal pellets and bituminite. Terrestrial organic matter is very rare in the surface sediments from the two deeps.

An autochthonous origin of the sedimentary organic matter as residues from bacteria and algae is reflected by the $n$-alkane spectra, which usually range from $n-\mathrm{C}_{15}$ to $n-\mathrm{C}_{25}$ (maximizing at $n-\mathrm{C}_{20}$ and $n-\mathrm{C}_{21}$ ).

The TOC-values correlate with the contents of the biomarker dinosterol in the sediments, which indicates that dinoflagellates are a major organic carbon source in the northern Red Sea. The biomarker cholesterol, however, which is produced by eukaryotes, is not overall related to the TOC values. Cholesterol concentrations are relatively low in sapropelic sediments and diatomaceous oozes from the Shaban deep.

The existence of (anaerobic) brine within both deeps over the total time-span covered by the analysed sediments is indicated by both the low (generally $<1$ ) pristane/phytane ratios and the occurrence of 22, 29, 30trisnorhopan-21-one (TNH). Hence, sapropel formation was caused by high bioproductivity rather than episodic stagnation within the deeps.

In the Red Sea TNH is only produced in significant amounts when the redoxcline corresponds with the brine-sea water density gradient of the individual deeps where much of the sedimenting organic matter accumulates. The biomarker $\mathrm{TNH}$ is an indicator for bacterial activity, although it does not allow quantification of bacterial intensity. Efficient, most likely aerobic bacterial degradation processes of organic substances (e.g. microbial degradation of intact bacteriohopanepolyols) produce TNH that is a major constituent of surface sediments in the deeps only. However, TNH formation was much reduced during postglacial high bioproductivity stages in the northern Red Sea (e.g. the Younger Dryas) when sapropelic sediments were deposited. At that time the redoxcline probably was higher in the water column and, consequently only 
anaerobic degradation of organic matter occurred at the brine-sea water interface.

Rock Eval pyrolysis indicates that the organic matter is of type II quality. Although variations are recorded for the hydrogen indices and the amounts of extractable organic matter the data suggest that a significant hydrocarbon formation did not occur in the sediments from the Kebrit and Shaban deep. Thus, hydrothermal hydrocarbon formation, which was formerly reported in the literature, is probably only of local importance.

\section{Acknowledgements}

The sediment cores were recovered during Meteor 31-2 cruise, which was funded by DFG through grants Sto 110/23-1 and He 697/17. The in situ filter samples were recovered during Meteor 52-3 campaign, which was partly funded through DFG grant Schm 1527/2-1. Surface sediment samples (MUC) were provided by J. Pätzold. Bathymetry grid data were provided by A. Erhardt. We are grateful to C. Ostertag-Henning, G. Scheeder and I. Dold for analytical support and discussions. TNH formation was discussed with J. Rullkötter. Two anonymous referees and the editor of Chemical Geology (L.M. Walter) made valuable reviews, which significantly improved the paper. We benefited from international cooperation with Saudi Arabia and Egypt. Partial support of 01-LECEMA21F (Transition from a continental to an oceanic rift: geology and biogeochemistry of the Northern Red Sea) project by the European Science Foundation under the EUROCORES Programme EUROMARGINS, through contract No. ERAS-CT-2003-980409 of the European Commission, DG research, FP6 is acknowledged.

\section{References}

Almogi-Labin, A., Hemleben, C., Meischner, D., Erlenkeuser, H., 1991. Paleoenvironmental events during the last 13,000 years in the central Red Sea as recorded by Pteropoda. Paleoceanography 6, 83-98.

Anschutz, P., Blanc, G., 1996. Heat and salt fluxes in the Atlantis II Deep (Red Sea). Earth Planet. Sci. Lett. 142, 147-159.

Arz, H.W., Berger, J., Donner, B., Al Farawati, R., Klann, M., Legge, H.L., Al Otibi, A., Ghandourah, M., Moammar, M., Pätzold, J., Seeberg-Elverfeldt, I., Schewe, F., 2002. Marine Geology. In: Pätzold, et al. (Ed.), METEOR-Berichte 03-2, Black SeaMediterranean-Red Sea, Part 3 (Cruise No. 52, Leg 3), pp. 19-27.

Arz, H.W., Lamy, F., Pätzold, J., Müller, P.J., Prins, M., 2003. Mediterranean moisture source for an early-holocene humid period in the northern red sea. Science 300, 118-121.

Bäcker, H., 1976. Fazies und chemische Zusammensetzung rezenter Ausfällungen aus Mineralquellen im Roten. Meer. Geol. Jb. D 17, 151.

Bäcker, H., Schoell, M., 1972. New deeps with brines and metalliferous sediments in the Red Sea. Nat., Phys. Sci. 240, 153-158.
Benlloch, S., Lopez-Lopez, A., Casamayor, E.O., Ovreas, L., Goddard, V., Daae, F.L., Smerdon, G., Massana, R., Joint, I., Thingstad, F., Pedros-Alio, C., Rodriguez-Valera, F., 2002. Prokaryotic genetic diversity throughout the salinity gradient of a coastal saltern. Environ. Microbiol. 4, 349-360.

Berggren, W.A., Boersma, A., 1969. Late Pleistocene and Holocene planktonic foraminifera from the Red Sea. In: Degens, E.T., Ross, A.D. (Eds.), Hot Brines and Recent heavy Metal Deposits in the Red Sea. Springer Verlag, Berlin, pp. 282-298.

Bignell, R.D., 1975. Timing, distribution and origin of submarine mineralization in the Red Sea. Appl. Earth Sci., Trans. B 84, 1-6.

Bignell, R.D., Cronan, D.S., Tooms, J.S., 1976. Red Sea metalliferous brine precipitates. Geol. Assoc. Can. Newsl. 14, 147 Special Paper.

Bischoff, J.L., 1969. Red Sea geothermal brine deposits: their mineralogy, chemistry, and genesis. In: Degens, E.T., Ross, D.A. (Eds.), Hot Brines and Recent Heavy Metal Deposits in the Red Sea. Springer Verlag, New York, pp. 368-401.

Blum, N., Puchelt, H., 1991. Sedimentary- hosted polymetallic massive sulfide deposits of the Kebrit and Shaban Deeps, Red Sea. Miner. Depos. 26, 217-227.

Bonatti, E., 1985. Punctiform initiation of seafloor spreading in the Red Sea during transition from a continental to an oceanic rift. Nature 316, 33-37.

Boon, J.J., Rijpstra, W.I.C., DeLange, F., DeLeeuw, J.W., Yoshioka, M., Shimizu, Y., 1979. Black Sea sterol-a molecular fossil for dinoflagellate blooms. Nature 277, 125-127.

Botz, R., Schmidt, M., Schmitt, M., 2002. Dissolved gases and extractable hydrocarbons at the brine-sea water boundary. In: Pätzold, J. (Ed.), METEOR-Berichte 03-2, Black Sea-Mediterranean-Red Sea, Part 3 (Cruise No. 52, Leg 3), pp. 35-43.

Brassel, S.C., Eglington, G., Marlowe, I.T., Pflaumann, U., Sarnthein, M., 1986. Molecular stratigraphy: a new tool for climatic assessment. Nature 320, 129-133.

Bray, E.E., Evans, E.D., 1961. Distribution of $n$-paraffins as a clue to recognition of source beds. Geochim. Cosmochim. Acta 22, 2-15.

Burke, R.A., Brooks, J.M., Sackett, W.M., 1981. Light hydrocarbons in Red Sea brines and sediments. Geochim. Cosmochim. Acta 45, $627-634$.

Calvert, S.E., 1983. Geochemistry of Pleistocene sapropels from the eastern Mediterranean. Oceanol. Acta 6, 255-267.

Cho, B., Azam, F., 1988. Major role of bacteria in biogeochemical fluxes in the ocean's interior. Nature 332, 441-443.

Conte, M.H., Dickey, T.D., Weber, J.C., Johnson, R.J., Knap, A.H., 2003. Transient physical forcing of pulsed export of bioreactive material of the deep Sargasso Sea. Deep-Sea Res., Part 1, Oceanogr. Res. Pap. 50, 1157-1187.

Coulibaly, A.S., Anschutz, P., Blanc, G., Malaize, B., Pujol, C., Fontanier, C., 2006. The effect of paleo-oceanographic changes on the sedimentary recording of hydrothermal activity in the Red Sea during the last 30,000 years. Mar. Geol. 226, 51-64.

Daffonchio, D., Borin, S., Brusa, T., Brusetti, L., van-der-Wielen, P.W.J.J., Bolhuis, H., Yakimov, M.M., D’Auria, G., Giuliano, L., Marty, D., Tamburini, C., McGenity, T.J., Hallsworth, J.E., Sass, A.M., Timmis, K.N., Tselepides, A., Lange, G.J.d., Hübner, A., Thomson, J., Varnavas, S.P., Gasparoni, F., Gerber, H.W., Malinverno, E., Corselli, C., 2006. Stratified prokaryote network in the oxic-anoxic transition of a deep-sea halocline. Nature 440 (9), 203-207.

Degens, E.T., Ross, D.A., 1969. Hot Brines and Recent Heavy Metal Deposits in the Red Sea. Springer Verlag, New York. 600 pp.

Deuser, W.G., Degens, E.T., 1969. O18/O16 and C13/C12 ratios of fossils from the hot-brine deep area of the central Red Sea. 
In: Degens, E.T., Ross, D.A. (Eds.), Hot brines and recent heavy metal deposits in the Red Sea. Springer Verlag, New York, pp. 336-347.

D'Hondt, S., Jørgensen, B.B., Miller, D.J., Batzke, A., Blake, R., Cragg, B.A., Cypionka, H., Dickens, G.R., Ferdelman, T., Hinrichs, K.-U., Holm, N.G., Mitterer, R., Spivack, A., Wang, G., Bekins, B., Engelen, B., Ford, K., Gettemy, G., Rutherford, S.D., Sass, H., Skilbeck, C.G., Aiello, I.W., Guèrin, G., House, C.H., Inagaki, F., Meister, P., Naehr, T., Niitsuma, S., Parkes, R.J., Schippers, A., Smith, D.C., Teske, A., Wiegel, J., Naranjo-Padilla, C., Luz-Solis-Acosta, J., 2004. Distribution of microbial activities in deep subseafloor sediments. Science 306, 2216-2221.

Didyk, B.M., Simoneit, B.R.T., Brassell, S.C., Eglinton, G., 1978. Organic geochemical indicators of palaeoenvironmental conditions of sedimentation. Nature 272, 216-222.

Dymond, J., Suess, E., Lyle, M., 1992. Barium in deep-sea sediment: a geochemical proxy for paleoproductivity. Paleoceanography 7, 163-181.

Eder, W., Jahnke, L.L., Schmidt, M., Huber, R., 2001. Microbial diversity of the brine sea-water interface of the Kebrit Deep, Red Sea, studied via 16S rRNA gene sequences and cultivation methods. Appl. Environ. Microbiol. 67, 3077-3085.

Eder, W., Schmidt, M., Koch, M., Garbe-Schönberg, D., Huber, R., 2002. Prokaryotic phylogenetic diversity and corresponding geochemical data of the brine-seawater interface of the Shaban Deep, Red Sea. Environ. Microbiol. 4, 758-763.

Edwards, F.J., 1987. Climate and oceanography. In: Edwards, F.J., Head, S.M. (Eds.), Red Sea. Pergamon Press, New York, pp. 45-70.

Eglinton, G., Hamilton, R.J., 1963. The distribution of alkanes. In: Swain, T. (Ed.), Chemical Plant Taxonomy. Academic Press, New York, pp. 187-217.

Erba, E., 1991. Deep mid-water bacterial mats from anoxic basin of the Eastern Mediterranean. Mar. Geol. 100, 83-101.

Erba, E., Rodondi, G., Parisi, E., TenHaven, H.L., Nip, M., Leeuw, J.W., 1987. Gelatinous pellicles in deep anoxic hypersaline basins from eastern Mediterranean. Mar. Geol. 75, 165-183.

Eshel, G., Naik, N.H., 1997. Climatological coastal jet collision intermediate water formation, and the general circulation of the Red Sea. J. Phys. Oceanogr. 24, 1233-1257.

Eshel, G., Cane, M.A., Blumenthal, M.B., 1994. Modes of subsurface, intermediate, and deep-water renewal in the Red Sea. Geophys. Res. 99, 15941-15952.

Espitalié, J., Laporte, J.L., Madec, M., Marquis, F., Leplat, P., Paulet, J., Boutefeu, A., 1977. Méthode rapide de caracterisation des roches méres de leur potentiel pétrolier et de leur degré d'évolution. Rev. Inst. Fr. Pet. 32, 23-42.

Faber, E., Botz, R., Poggenburg, J., Schmidt, M., Stoffers, P., Hartmann, M., 1998. Methane in Red Sea brines. Org. Geochem. 29 (1-3), 363-379.

Fenton, M., Geiselhart, S., Rohling, E.J., 2000. Aplanktonic zones in the Red Sea. Mar. Micropaleontol. 40, 277-294.

Freeman, K.H., Hayes, J.M., Trendel, J.-M., Albrecht, P., 1990. Evidence from carbon isotope measurements for diverse origins of sedimentary hydrocarbons. Nature 343, 254-256.

Gagosian, R.B., Smith, S.O., Nigrelli, G.E., 1982. Vertical transport of steroid alcohols and ketones measured in a sediment trap experiment in the equatorial Atlantic Ocean. Geochim. Cosmochim. Acta 46, 1163-1172.

Gevirtz, J.L., Friedman, G.M., 1966. Deep sea carbonate sediments of the Red Sea and their implications on marine lithification. J. Sediment. Petrol. 36, 143-152.

Grimalt, T., Albaigès, J., 1987. Sources and occurrence of C12-C22 $n$-alkane distributions with even carbon-numbered preference in sedimentary environments. Geochim. Cosmochim. Acta 51, $1379-1384$.

Grootes, P.M., Nadeau, M.-J., Rieck, A., 2004. ${ }^{14}$ C-AMS at the Leibniz-Labor: radiometric dating and isotope research. Nucl. Instrum. Methods Phys. Res., B Beam Interact. Mater. Atoms 223224, 55-61.

Han, J., McCarthy, E.O., Benn, M.H., 1968. Hydrocarbon constituents of the blue-green algae Nostoc muscorum Anacystis midulans, Phormidium luridum and Chlorogloea fritschii. J. Chem. Soc., C, Org. 2785-2791.

Hartmann, M., Scholten, J.C., Stoffers, P., Wehner, F., 1998a. Hydrographic structure of brine-filled deeps in the Red Seanew results from the Shaban, Kebrit, Atlantis II, and Discovery Deep. Mar. Geol. 144, 311-330.

Hartmann, M., Scholten, J.C., Stoffers, P., 1998b. Hydrographic structure of brine-filled deeps in the Red Sea: correction of Atlantis II Deep temperatures. Mar. Geol. 144, 331-332.

Hemleben, C., Roether, W., Stoffers, P., 1996a. Östliches Mittelmeer, Rotes Meer, Arabisches Meer. RV Meteor-Cruise No.31. MeteorBerichte 96-4, 1-282.

Hemleben, C., Meischner, D., Zahn, R., Almogi-Labin, A., Erlenkeuser, H., Hiller, B., 1996b. Three hundred eighty thousand year long stable isotope and faunal records from the Red sea: influence of global sea level change on hydrography. Paleoceanography 10 , $147-156$

Herman, Y., 1965. Evidence of climatic changes in Red Sea cores. Congr. Int. Assoc. Quat. Res. 325-348.

Hufnagel, H., Porth, H., 1989. Organopetrographic studies in the Visayan Basin, Philippines. Geol. Jahrb. 70, 349-384.

Ivanova, E.V., 1985. Late Quaternary biostratigraphy and paleotemperatures of the Red Sea and the Gulf of Aden based on planktonic foraminifera and pteropods. Mar. Micropaleontol. 9, 335-364.

Johnson, R.W., Calder, J.R., 1973. Early diagenesis of fatty acids and hydrocarbons in a salt marsh environment. Geochim. Cosmochim. Acta 37, 1943-1955.

Kaplan, I.R., Baedecker, M.J., 1972. Biological productivity in Dead Sea part II: evidence for phosphatidyl glycerophosphate lipids in sediments. Isr. J. Chem. 8, 529-533.

Kasten, S., Haese, R.R., Zabel, M., Rühlemann, C., Schulz, H.D., 2001. Barium peaks at glacial terminations in sediments of the equatorial Atlantic Ocean-relicts of deglacial productivity pulses? Chem. Geol. 175, 635-651.

Kemp, A.E.S., 1996. Laminated sediments as paleo-indicators. In: Kemp, A.E.S. (Ed.), Palaeoclimatology and Palaeoceanography from Laminated Sediments. Geol. Soc. London Spec., London, pp. vii-xii.

Kemp, A.E.S., Pike, J., Pearce, B., Lange, C.B., 2000. The "fall dump" a new perspective on the role of a "shade flora" in the annual cycle of diatom production and export flux. Deep-Sea Res., Part 2, Top. Stud. Oceanogr. 47, 2129-2154.

Kiriakoulakis, K., Stutt, E., Rowland, S.J., Vangriesheim, A., Lampitt, R.S., Wolff, G.A., 2001. Controls on the organic chemical composition of settling particles in the Northeast Atlantic Ocean. Prog. Oceanogr. 50, 65-87.

Kolattukudy, P.E., Walton, T.J., 1972. The biochemistry of plant cuticular lipids. In: Holman, R.T. (Ed.), Progress in the Chemistry of Fats and Other Lipids. Pergamon, New York, pp. 121-175.

Langford, F.F., Blanc-Valleron, M.-M., 1990. Interpreting Rock-Eval pyrolysis data using graphs of pyrolizable hydrocarbons vs. total organic carbon. AAPG Bull. 74 (6), 799-804.

Legge, H.L., Mutterlose, J., Arz, H.W., 2006. Climatic changes in the northern Red Sea during the last 22,000 years as recorded by 
calcareous nannofossils. Paleoceanography 21. doi:10.1029/ 2005PA001142 PA 1003.

Levanon-Spanier, I., Padan, E., Reiss, Z., 1979. Primary production in a desert-enclosed sea - The Gulf of Elat (Aqaba), Red Sea. DeepSea Res., Part 1, Oceanogr. Res. Pap. 26, 673-685.

Lichtfouse, E., Derenne, S., Mariotti, A., Largeau, C., 1994. Possible algal origin of long chain odd $n$-alkanes in immature sediments as revealed by carbon isotope ratios. Org. Geochem. 22 (6), $1023-1027$.

Littke, R., Lückge, A., Welte, D.H., 1997. Quantification of organic matter degradation by microbial sulphate reduction for quaternary sediments from the Northern Arabian Sea. Naturwissenschaften 84, 312-315.

Locke, S., Thunell, R.C., 1988. Paleoceanographic record of the last glacial/interglacial cycle in the Red Sea and Gulf of Eden. Palaeogeogr. Palaeoclimatol. Palaeoecol. 64, 163-187.

Löwemark, L., Lin, Y., Chen, H.-F., Yang, T.-N., Beier, C., Werner, F., Lee, C.-Y., Song, S.-R., Kao, S.-J., 2006. Sapropel burn-down and ichnological response to late Quaternary sapropel formation in two $\sim 400 \mathrm{ky}$ records from the eastern Mediterranean Sea. Palaeogeogr. Palaeoclimatol. Palaeoecol. 1-20. doi:10.1016/j. paleo.2006.02.013.

Macko, S.A., Engel, M.H., Qian, Y., 1994. Early diagenesis and organic matter preservation - a molecular stable carbon isotope perspective. Chem. Geol. 114, 365-379.

Maillard, C., 1972. Eaux intermediaries et formation d'eau profonde en Mer Rouge, L'ocèanographie physique de la Mer Rouge. Acte des Colo ques. CNEXO, Paris, pp. 105-133.

Manheim, F.T., 1974. Red Sea geochemistry. Initial Reports of the Deep Sea Drilling Project vol. 23, 975-998.

McLennan, S.M., Murray, R., 1999. Geochemistry of sediments. In: Marshall, C.P., Fairbridge, R.W. (Eds.), Encyclopedia of Geochemistry. Kluwer Academic Publishers, London, pp. 282-292.

Meyers, P.A., Ishiwatari, R., 1993. Lacustrine organic geochemistry: an overview of indicators of organic matter sources and diagenesis in lake sediments. Org. Geochem. 20, 867-900.

Michaelis, W., Jenisch, A., Richnow, H.H., 1990. Hydrothermal petroleum generation in Red Sea sediments from the Kebrit and Shaban Deeps. Appl. Geochem. 5, 103-114.

Milliman, J.D., Ross, D.A., Ku, I.L., 1969. Precipitation and lithification of deep sea carbonates in the Red Sea. J. Sediment. Petrol. 39, 724-736.

Missak, E.A., 1988. Mineralogy and phase relations of the massive sulphides and metalliferous sediments of the axial rift valley, Red Sea. Heidelb. Geowiss. Abh. 23, 213.

Müller, P.J., Kirst, G., Ruhland, G., von Storch, I., Rosell-Mele, A., 1998. Calibration of the alkenone palaeotemperature index UK 37 based on core-tops from the eastern South Atlantic and the global ocean $\left(60^{\circ} \mathrm{N}-60^{\circ} \mathrm{S}\right)$. Geochim. Cosmochim. Acta $62,1757-1772$.

Muri, G., Wakeham, S.G., Pease, T.K., Faganeli, J., 2004. Evaluation of lipid biomarkers as indicators of changes in organic matter delivery to sediments from Lake Planina, a remote mountain lake in NW Slovenia. Org. Geochem. 35, 1083-1093.

Olausson, E., 1961. Studies of the deep-sea cores. Rep. Swed. DeepSea Exped., 1947-1948 8, 353-391.

Orò, J., Tornabene, T.G., Nooner, D.W., Gelpi, E., 1967. Aliphatic hydrocarbons and fatty acids of some marine freshwater microorganisms. J. Bacteriol. 93, 1811-1818.

Parkes, R.J., Webster, G., Cragg, B.A., Weightman, A.J., Newberry, C.J., Ferdelman, T.G., Kallmeyer, J., Jorgensen, B.B., Aiello, I.W., Fry, J.C., 2005. Deep sub-seafloor prokaryotes stimulated at interfaces over geological time. Nature 436, 390-394.

Pautot, G., Guennoc, P., Coutelle, A., Lyberis, N., 1984. Discovery of a large brine deep in the northern Red Sea. Nature 310, 133-136.
Petrick, G., Schulz-Bull, D.E., Martens, V., Scholz, K., Duinker, J.C., 1996. An in-situ filtration/extraction system for the recovery of trace organics in solution and on particles tested in deep ocean water. Mar. Chem. 54, 97-105.

Preussag, 1984. Metal Exploration of the Northern Red Sea. Technical Summary. PREE-CR-05-1.

Quadfasel, D., Baudner, H., 1993. Gyre-scale circulation cells in the Red Sea. Oceanol. Acta 16, 221-229.

Rock Color Chart, 1991. ROCK COLOR CHART: Boulder, Colorado. Geological Society of America.

Rontani, J.F., Beker, B., Volkman, J.K., 2004. Long-chain alkenones and related compounds in the benthic haptophyte Chrysotila lamellosa Anand HAP 17. Phytochemistry 65, 117-126.

Rontani, J.F., Prahl, F.G., Volkman, J.K., 2006. Re-examination of the double bond positions in alkenones and derivatives: biosynthetic implications. J. Phycol. 42 (4), 800-813.

Rossignol-Strick, M., 1987. Rainy periods and bottom water stagnation initiating brine accumulation and metal concentration: 1. The late Quaternary. Paleoceanography 2, 333-360.

Rossignol-Strick, M., Nesteroff, W.D., Olive, P., Vergnaud-Grazzini, C., 1982. After the deluge: Mediterranean stagnation and sapropel formation. Nature 295, 105-110.

Sachse, D., Radke, J., Gleixner, G., 2004. Hydrogen isotope ratios of recent lacustrine sedimentary $n$-alkanes record modern climate variability. Geochim. Cosmochim. Acta 68, 4877-4889.

Sackett, W.M., 1989. Stable carbon isotope studies on organic matter in the marine environment. In: Fritz, P., Fontes, J.C. (Eds.), Handbook of Environmental isotope Geochemistry vol. 3, 139-169.

Santos, V., Billett, D.S.M., Rice, A.L., Wolff, G.A., 1994. Organic matter in deep-sea sediments from the Porcupine Abyssal Plain in the north-east Atlantic Ocean. I - lipids. Deep-Sea Res., Part 1, Oceanogr. Res. Pap. 41, 787-819.

Saxby, I.D., 1972. Organic matter in Red Sea sediments. Chem. Geol. 9, 233-240.

Schmidt, M., Botz, R., Faber, E., Schmitt, M., Poggenburg, J., GarbeSchönberg, D., Stoffers, P., 2003. High-resolution methane profiles across anoxic brine-seawater boundaries in the Atlantis-II, Discovery, and Kebrit deeps (Red Sea). Chem. Geol. 200, 359-375.

Schmidt, M., Botz, R., Aeschbach-Hertig, W., Bayer, R., Schmitt, M., Böttcher, M., Stoffers, P., Bonatti, E., 2006. Biogeochemistry of brines in the Northern Red Sea, EGU General Assembly, Wien, EGU06-A-04400.

Scholten, J., Stoffers, P., Garbe-Schönberg, D., Moammar, M., 2000. Hydrothermal Mineralization in the Red Sea. In: Cronan, D.S. (Ed.), Marine Mineral Deposits, pp. 369-395.

Seeberg-Elverfeldt, I.A., Lange, C.B., Arz, H.W., Pätzold, J., Pike, J., 2004a. The significance of diatoms in the formation of laminated sediments of the Shaban Deep, Northern Red Sea. Mar. Geol. 209, 279-301.

Seeberg-Elverfeldt, I.A., Lange, C.B., Pätzold, J., 2004b. Preservation of siliceous microplankton in surface sediments of the northern Red Sea. Mar. Micropaleontol. 51, 193-211.

Seeberg-Elverfeldt, I.A., Lange, C.B., Pätzold, J., Kuhnt, G., 2005. Laminae type and possible mechanisms for the formation of laminated sediments in the Shaban Deep, northern Red Sea. Ocean Sci. 1, 113-126.

Siddall, M., Smeed, D.A., Hemleben, C., Rohling, E.J., Schmelzer, I., Peltier, W.R., 2004. Understanding the Red Sea response to sea level. Earth Planet. Sci. Lett. 225, 421-434.

Silliman, J.E., Meyers, P.A., Bourbonniere, R.A., 1996. Record of postglacial organic matter delivery and burial in sediments of Lake Ontario. Org. Geochem. 24, 463-472. 
Simoneit, B.R.T., 1978a. Organic chemistry of marine sediments. In: Chester, R., Riley, J.P. (Eds.), Chemical Oceanography. Academic Press, London, pp. 233-311.

Simoneit, B.R.T., 1978b. Organic geochemistry of terrigenous muds and various shales from the Black Sea. DSDP Leg 42B. Init. Reports DSDP, vol. 42 (2), pp. 749-753.

Simoneit, B.R.T., Grimalt, J.O., Hayes, J.M., Hartman, H., 1987. Low temperature hydrothermal maturation of organic matter in sediments from the Atlantis II Deep, Red Sea. Geochim. Cosmochim. Acta 51, 879-894.

Sofianos, S.S., Johns, W.E., 2002. An Oceanic General Circulation Model (OGCM) investigation of the Red Sea circulation,1, Exchange between the Red Sea and the Indian Ocean. J. Geophys. Res. 107 (C11), 3196. doi:10.1029/2001JC001184.

Stach, E., Mackowsky, M.T., Teichmüller, M., Taylor, G.H., Chandra, D., 1982. Stach's Textbook of Coal Petrology. Borntraeger Verlag, Berlin. 518 pp.

Stoffers, P., Botz, R., 1989. Carbonate Crusts in the Red Sea: Their Composition and Isotope Geochemistry. In: Ittekott, V., Kempe, S., Michaelis, W., Spitzy, A. (Eds.), Facets of modern biogeochemistryFestschrift for E. T. Degens. Springer Verlag, Berlin, pp. 242-252.

Stoffers, P., Botz, R., Scholten, J., 1990. Isotope geochemistry of primary and secondary carbonate minerals in the Shaban-Deep (Red Sea). In: Heling, D., Rothe, P., Förster, U., Stoffers, P. (Eds.), Sediments and Environmental Geochemistry. Springer Verlag, Berlin, pp. 83-94.

Stoffers, P., Moammar, M., Abu-Ouf, M., Ackermand, D., Alassif, O., Al-Hazim, Y., Boldt, S., Botz, R., Eder, W., El-Garafi, A., ElMamoney, M., Fleitmann, D., Garbe-Schönberg, D., Geiselhart, S., Goedecke, D., Hartmann, M., Klauke, S., Moussa, K., Mühlhan, N., Mühlstrasser, T., Poggenburg, J., Rehder, W., Schmidt, M., Schmitt, M., Schoeps, D., Scholten, J., Shbalaby, M., Wismann, A., Yohannes, E., 1998. Hydrography, hydrothermalism and paleoceanography in the Red Sea. Berichte-Reports Geol. Paläont. Inst. Univ. Kiel, vol. 88. 107 pp.

Stuiver, M., Polach, H.A., 1977. Discussion; reporting of C-14 data. Radiocarbon 19, 355-363.

TenHaven, H.L., DeLange, G.J., Klaver, G.T., 1985. The chemical composition and origin of the Tyro brine, eastern Mediterranean. A tentative model. Mar. Geol. 64, 337-342.
TenHaven, H.L., Baas, M., Leeuw, J.W.D., Maassen, J.M., Schenck, P.A., 1987. Organic geochemical characteristics of sediments from the anoxic brine-filled Tyro basin (eastern Mediterranean). Org. Geochem. 11, 605-611.

Thunell, R.C., Locke, S.M., Williams, D.F., 1988. Glacio-eustatic sealevel control on Red Sea salinity. Nature 334, 601-604.

Tissot, B.P., Welte, D.H., 1984. Petroleum Formation and Occurrence. Springer-Verlag, Berlin. 699 pp.

Volkman, J.K., Eglinton, G., Corner, E.D.S., Forsberg, J.R., 1980. Long chain alkenes and alkenones in the marine coccolithophorid Emiliania huxleyi. Phytochemistry 19, 2619-2622.

Wakeham, S.G., Hedges, J.I., Lee, C., Petersen, M.L., Hernes, P.J., 1997. Compositions and transport of lipid biomarkers through the water column and surficial sediments of the equatorial Pacific Ocean. Deep-Sea Res., Part 2, Top. Stud. Oceanogr. 44, 2131-2162.

Weber Jr., F.F., Sackett, W.M., 1981. Uranium geochemistry at Orca Basin. Geochim. Cosmochim. Acta 45, 1321-1329.

Weikert, H., 1982. The vertical distribution of zooplankton in relation to habitat zones in the area of the Atlantis II Deep, central Red Sea. Mar. Ecol., Prog. Ser. (Halstenbek) 8, 129-143.

Werner, F., Lange, K., 1975. A bathymetric survey of the sill area between the Red Sea and the Gulf of Aden. Geol. Jahrb., Reihe D Mineral. Petrogr. Geochem. Lagerstattenkd. 13, 125-130.

Williams, D.F., Thunell, R.C., Kennett, J.P., 1978. Periodic freshwater flooding and stagnation of the eastern Mediterranean Sea during the Late Quaternary. Science 201, 252-254.

Woelk, S., Quadfasel, D., 1996. Renewal of deep water in the Red Sea during 1982-1987. J. Geophys. Res. 101 (C8), 18155-18165.

Youngblood, W.W., Blumer, M., Guillard, R.L., Fiore, F., 1971. Saturated and unsaturated hydrocarbons in marine benthic algae. Mar. Biol. 8, 190-201.

Zegouagh, Y., Derenne, S., Largeau, C., Bardoux, G., Mariotti, A., 1998. Organic matter sources and early diagenetic alterations in Arctic surface sediments (Lena River delta and Laptev Sea, Eastern Siberia), II. Molecular and isotopic studies of hydrocarbons. Org. Geochem. 28, 571-583. 